\title{
The Wondrous Bird's Nest II
}

Hans jacob Christoffel von Grimmelshausen

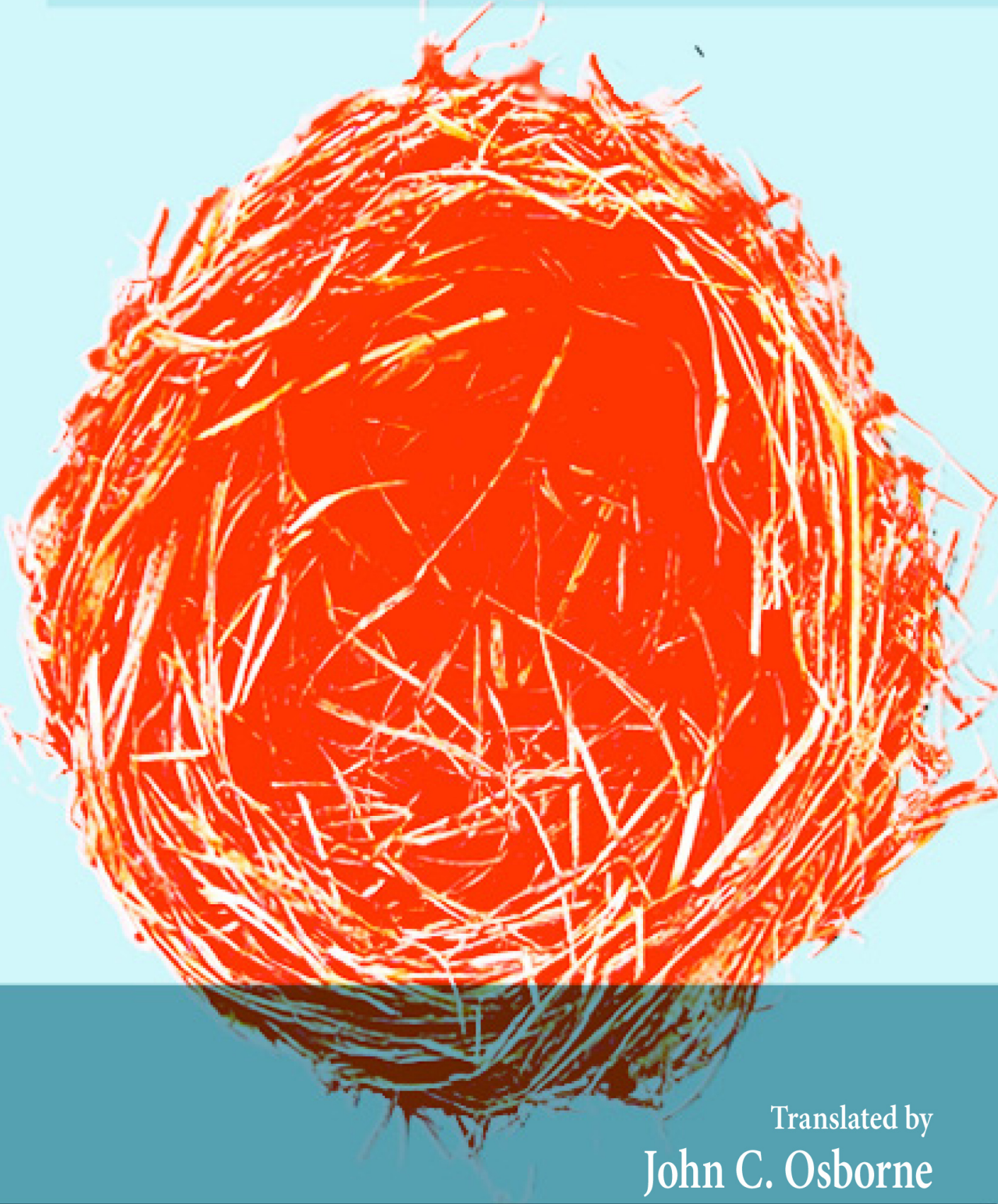



The Wondrous Bird's Nest II 



\title{
The Wondrous Bird's Nest II
}

Hans Jacob Christoffel von Grimmelshausen

\author{
Translated by \\ John C. Osborne
}


The Wondrous Bird's Nest II

(C) 2011 by Martha Lee Osborne

Digital version at www.newfoundpress.utk.edu/pubs/osborne2

Newfound Press is a digital imprint of the University of Tennessee Libraries. Its publications are available for non-commercial and educational uses, such as research, teaching and private study. The author has licensed the work under the Creative Commons Attribution-Noncommercial 3.0 United States License. To view a copy of this license, visit http://creativecommons.org/licenses/by-nc/3.0/us/

For all other uses, contact:

Newfound Press

University of Tennessee Libraries

1015 Volunteer Boulevard

Knoxville, TN 37996-1000

www.newfoundpress.utk.edu

ISBN-13: 978-0-9846445-1-3

ISBN-10: 0-09846445-1-2

Grimmelshausen, Hans Jakob Christoph von, 1625-1676.

[Wunderbarliche Vogelnest II. English]

The wondrous bird's nest II / Hans Jacob Christoffel von Grimmelshausen ;

translated by John C. Osborne.

xiii, 187 p. : digital, PDF file.

Translation of: Wunderbarliche Vogelnest II.

1. Thirty Years' War, 1618-1648 -- Fiction.

I. Osborne, John C., 1928- II. Title.

PT1731.A4 E589 2011

Book design by Jayne W. Rogers

Cover design by Andrea E. Markel 


\section{contents}

Privileges and Licenses bestowed on this Little Work............ vii

Preface to the Gentle Reader ............................... xi

Chapter One: The effect of money, both when one has much of it and

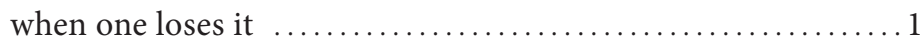

Chapter Two: Portrait of the Magician ...................... 7

Chapter Three: For what the lost treasure was exchanged $\ldots \ldots \ldots \ldots 13$

Chapter Four: A very serious case of spooning, in fact, nearly two of

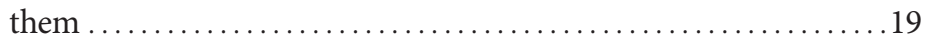

Chapter Five: The invisible man sees the groundwork laid to a structure with which horns were to be placed on his head ...........27

Chapter Six: One good turn for another, and a gratuity for the maid.

Chapter Seven: How one makes women a delicacy repugnant to women.

Chapter Eight: An artful fence to prevent strange bulls from getting in your stall or cuckoos from laying their eggs in your nest.....47

Chapter Nine: One whoreson deceives the other, and the innocent party gets the short end of the stick..................... 55

Chapter Ten: Journey to St. Michael's Fair in Leipzig, and thence to Amsterdam....................................61

Chapter Eleven: How is one to plan ahead now? Will war break out, or shall we remain at peace?

Chapter Twelve: The best remedy for war is sought and found, but the worst is chosen

Chapter Thirteen: What the Jews think about Elias and believe about their future hoped-for Messiah. 
Chapter Fourteen: Elias comes as a dinner guest, the Angel Uriel announces the coming of the Jewish Messiah, and other great miraculous signs occur ....

Chapter Fifteen: The Messiah is fathered by Elias, carried by Esther and at last of the great mountains only a ridiculous little mouse is born 101

Chapter Sixteen: How Erasmus reacted, and how he was relieved of his attacks of anxiety 107

Chapter Seventeen: Anyone who wishes to know what is in this chapter must either read it himself or have someone read it to him unless, of course, someone has already told him about it....113

Chapter Eighteen: A golden fish lure with a wooden fish pole, and other dodges

Chapter Nineteen: Cow and calf are put in the same stall .... 125

Chapter Twenty: What else transpired before, during and after the wedding

Chapter Twenty-One: What the desperate man then undertook. 139

Chapter Twenty-Two: What else happened, and what is to be learned from this vision

Chapter Twenty-Three: How the campaign began and proceeded ... 153

Chapter Twenty-Four: How the miserable ninny was delivered from his lamentable condition and set aright again

Chapter Twenty-Five: The actual truth about ways of achieving invulnerability

Chapter Twenty-Six: Continuation of the foregoing material and of other matters of that kind

Chapter Twenty-Seven: Homeward Journey and Conclusion of this little War. 


\section{Privileges and Licenses bestowed on this Little Work}

This little work has received the express permit from the great and, of course invisible, and therefore also very most invincible potentate of the world's great and very most populous province, Selenitas (wherein the women, as Lucianus attests, lay whole baskets full of eggs and hatch from them human beings of their type by the score), namely that anyone may buy it who has the desire, the love, and the money to do so, be he learned or unlearned, rich or poor, a big fish or a little fish, clergyman or layman, man or woman, foolish or sensible, single or married, boy or girl. And any of the above-mentioned persons who takes it in hand may read it too (but with the express proviso that he be able to read), unless it be solemnly forbidden him by a particular high power which is authorized to do so for legal reasons, and is strong enough to put into effect the prohibition he has imposed.

'Tis also granted and permitted that anyone may, at his very best judgment, at times lay it aside and take it back to hand again at his own free will, as often as he please and as time allow; so that no one shall be compelled to read it over once or at one sitting, unless it be done solely to pass the time or to fish teachings out of it which the author has secretly concealed in it; on the other hand, any possessor of this little treatise is not prohibited, if he has not enough with one reading, or else has a short memory, from reading it through two, three, four, yea even seventeen times, and even from putting it under his pillow at night, as Alexander Magnus did his Homer; but with this reserve: that the Reformed do not, because of it, forget their Jobwasser, the Evangelicals, their Habermann, and the Catholics their 
Thomas à Kempis. And anyone, whether or not he thinks to maintain by his oath that he be related to neither Momus nor Zoilus, may criticize, judge, scorn, disparage, gloss, correct, and rake over the coals this little treatise, even though he neither understands it nor can do it better. In addition, there is the added bene that any fellow, be he ever so solemn and grave, may, unhindered and without objection from any party, and without damage to both his reputation and his tender conscience, boldly toss this little work as soon as he has grown tired of it, into the water, into the fire, or even into Pilatus' secret chancellery, even though this little work be bound in green satin or purple velvet, adorned with gilt edges, and secured with silver locks like a favorite prayer book; or, if he wishes to be economical about it, he may trade it to our Italian spice-merchant for a tin full of snuff, if only the book dealer has received his honest payment for it, without anyone's having held him or publicly proclaimed him to be a wondrous-strange wormy phantast because of this sharp procedure. But it is left up to them, prior to such serious measures, either to give it away to someone else in gratitude for services rendered, or to lend it to someone without expecting it ever to be returned. Over and beyond all this, the mighty and great king of Selenitas gives without limitation to everyone who deals with paper and whatever is on it the complete might, the free will, the untrammeled power, and the deputed right to reprint, offer for sale, sell, exchange, and vend and exploit to their best advantage, anywhere and everywhere, this little treatise in the German language, when and so often as they please, but with the express reservation and proviso that anyone who pirates it admit, and be willing also to supply sufficient guarantee for the extent to which he does not care in the least about acting contrary to the law, but instead through pirating books is intent upon stealing bread, like a thief, from the mouths of his fellow man, and particularly, from that of the original publisher; by which should by 
no means be understood those who know and are intent upon doing what befits honorable folk, nor those either who might wish to translate this little treasure from High German into another language and thereby have it printed in a non-German language for the benefit of non-German nations, all of this in accord with the privilegia in the original, with the threatened punishment that the oft-mentioned great king of the Selenitati has resolved to send to plague the lawbreakers of his realm-ugly and reprehensible creatures, which we are wont to call monsters and macroephalia, just as Jupiter did in the past with his harpies, all of this as stipulated in the oft-referred to originalia. Under the authentic signature of the oftentimes-mentioned just king, de dato in the capital and royal city Invisibilis, the 33rd day of the month Inauditas, Anno post nihil 00000.

Naughtother Rex Selenitatae

(L.S.)

Nemonius, Secretary. 



\section{Preface to the centle Reader}

Just as the Simplician author sought in the first part of his Wondrous Bird's Nest naught save to remind people that they might always, in all their commissions and omissions, all their actions and transactions, have the Divine Presence before their eyes and ought not ever to ignore or leave it unconsidered, so, in this second part, he wishes to loyally warn them against contracting and consorting with the evil spirit, in which dealings many a person quite easily and without noticing it at all, before he himself knows or imagines it, can stray with a wretched alliance with him and thus into eternal damnation, not only when he himself employs wicked and forbidden magic arts or deeds to learn them, but also when he seeks aid and counsel from the devil's manservants and maidservants, the so-called wise men and women, or (to call them by their right name) devil-conjurers, spell-layers, old witches and broomstick-riders, or only goes around with them or cultivates the least intimacy with them. Now what the afore-mentioned author thought to do in the aforesaid first part of the Bird's Nest alluded to, namely to teach men how they will be able quite easily to protect themselves from sin, was done before him, and in fact more than two thousand years ago, by the wise man when he said in brief words: "In all thy deeds, think of thy last hour, and thou wilt never, ever sin."

Our oft-mentioned author, however, makes so bold as to do this much more briefly and powerfully; for how much more will man eschew heinous sinning if he knows that he is everywhere accompanied and observed by Him Who will in the future actually reward 
and punish him for his commissions and omissions. If a person is loath to commit a shameful, vicious deed in the presence of another (who is of his ilk anyway, and a sinner, and perchance much more godless than he is), how much more will he eschew that deed, or ever the slightest sin if he does what the bird's nest teaches him, namely that he keep in mind in what measure our Most Holy God, Who hates sin, our Most Just God, Who leaves neither good unrewarded nor evil unpunished, our Most Powerful God, Whose hand and divine power none can escape, is everywhere looking on. In this serious matter this author has, to be sure, used his customary merry stilus and has included many funny anecdotes, as he also did in the description of the life of the adventurous Simplicissimus, so that of seventeen readers hardly one will find there what he wishes to teach him; rather most will believe that he composed his writing only to amuse; but that does not deter him from continuing on the path on which he set out. Reasonable folks, for whom it will be of profit, will assuredly find the kernel and know how to make it of use to them. 'Tis well known how unwillingly patients are to swallow bitter but healing pills, but on the other hand take easily those coated with gold or sugar; therefore he has imitated the cautious physicians and so sweetened the sharp bitterness of his satirical writings that some unpolished folk enjoy them not as healing medicine but rather as unhealthful sweets. Now despite the denigration and ill will of such people, and of saturnists and mule-in-colic folk who are deans and publicly proclaim everything, save what they have done, twaddle, he has remained free to his old manner of conscientiously warning heedless people (and with examples), in the guise of amusing stories, about what, as aforesaid, may quite easily sunder them from the highest good and bring them into the wretched devil's power and, if our dear God, out of particular mercifulness, does not help them, bringing them without doubt to eternal damnation, which he (the 
author) was primarily moved to do when he saw how in these present wretched times, perhaps the last times in history, countless numbers of people trouble themselves with all manners of wicked magic arts, without the one or the other feeling any pangs of conscience about what he is doing, nor remarking that he is already on the way to being stuck in the jaws of hell's abyss. Otherwise, this might regretfully be considered the tenth part or book of The Description of the Life of the Adventurer Simplicius, namely if Courasche were taken to be the seventh, Heedless Hopalong his eighth, and the first part of the Wondrous Bird's Nest the ninth book, since all of these Simplician writings are connected to one another, and neither the entire Simplicissimus nor any one of the above-mentioned little treasures can be sufficiently understood out of its context. The author thus wishes herewith to express his kind and friendly regards and wishes the reader the very best. 



\section{Chapter One}

The effect of money, both when one has much of it and when one loses it

For a person with the itch, 'tis almost impossible to leave off scratching, even though he can imagine the future pains which he is causing by doing so, and which he has also perchance felt heretofore, even though he sees people who laugh at the foolish gestures-the fletching teeth, the contorted mouth and wrinkled nose-which he makes during such energetic itching, together with his impatience with his own skin, which itching he makes twice as bad as his scratching. But what is the reason that they laugh at him? The reason is that these mockers do not themselves have the itch; else they would indeed leave off their scoffing. How should one who has not tried a thing know what it tastes like? He may indeed make a guess, but he is far from knowing for sure, like that peasant boy who praised the goodness of snipe shit over all other delicious dishes, not, to be sure, because he himself had eaten any of it, but because his grandfather had once said that his own great-great-grandfather had ages ago seen it spread on white rolls and baked in butter, eaten with pleasure by his squire, and had heard it praised.

But this is a different matter. I shall go along with the old proverb: the proof of the pudding is in the eating. No one can believe how bleeding taken on the shin bone hurts and prickles like a bee sting or a hackle, unless he has felt it himself.

I have heard spiritual shepherds of all manner of religions rumble (I came within a hair of saying "thunder") against it, both in public sermons and private conversations, on the basis of Holy Scripture as well as other weighty reasons, when they learned that common folk 
who had either sick children, sick servants, or sick animals, or from whom something had been stolen, or which they themselves had carelessly mislaid or even lost, and run to the old women, so called "wise men," or, to be more accurate, to the necromantic scoundrels, the sieve-shakers, the soothsayers, and such like rabble as were merely suspected of being privy to arts which, if not downright devilish, were at least forbidden. $\mathrm{O}$ the blessed zeal of such pious and loving pastors! O the certain aid and counsel of which the errant little lambs might then with consolation have availed themselves when lured by Satan into repugnant adventures, incited by his apostles with the promise of certain aid, compelled as it were by their own painful temptations, and thus from all sides both emboldened and teased, as well as spurred on sharply, to stray from the proper path! O holy providential care of such faithful fathers, who with such honest zeal endeavor in this way to protect us wretch idiots, us poor, blind, ignorant laymen on this our perilous journey, from the magic arts, from idolatry, and thus from the loss of our souls and from eternal ruin, but rather, in keeping with their honorable profession, endeavor to deliver us into the bosom of Abraham; but since according to right reason, it is to be concluded that one who seeks aid and refuge with the enemy of God and with that enemy's emissaries, even though he not find it, is afterwards no longer worthy of the aid of God and his saints, but that our loving God now and again nevertheless, through his paternal goodness, helps up again the one or the other who has fallen, and takes him into his grace-for this only His boundless mercy is to be thanked.

But, dear reader, just consider what the thousand-fold crafty archenemy of both the heavenly host and the human race undertakes when he sees that we are following so obediently our faithful fathers, scorning him together with his prophets, and relying on God alone. Just look at his slyness!! 
Through the practitioners of his damnable art he has it spread abroad that some of those very clergymen who have resisted this art most violently of all, almost as if they wished to extirpate it with fire and the sword, have run to them and without hesitation availed themselves of their aid, in order to persuade us poor ignoramuses so that we shall think and in our blind simple-mindedness say: "Oho! If our devout fathers, devoted only to God, have done that, then who is to think evil of us if we follow their example? If it is all right for them, then it is all right for us; for where the abbot throws the dice, the convent is permitted to gamble."

And indeed, what is more common, better known, and from experience more certain than that those folk who are at sea and in danger of drowning seize the nearest thing they can reach (and even if it were a sharp hedge of thorns or only a weak and fragile blade of grass), and grasp it so tight and hold on to it tenaciously in life and death that even after their death (unless they defy and overcome this strangler in the water) one has great trouble getting it out of their hands again.

But do not for that reason imagine, much less believe (as I foolishly did in times past), that clergymen seek in their need the aid of necromancers, for they are much too holy and too reasonable to do that. One of them would rather let his horse, which cost him a hundred sovereigns even though it had been ridden by a thousand witches, perish a hundred thousand times than ask a soothsayer for help with even the slightest nod of the head, indeed, even if it were a matter of life and death; for they know that just as they have lived in the Lord, they shall also therefore die in the Lord.

Therefore they are much more conscientious and more cautious than I was, and act far differently than I did when the Hopalongian hurdy-gurdy girl fished out all my gold and silver, as much of it as I disposed over in assorted crude coins. 
O ye accursed riches! Whatever did you do to me! As long as I possessed you, you burdened me with such a load of pride, which by itself would have been enough to push me down into the deepest abyss of hell, not to mention in what manner your superabundance downright paved the way to damnable lusts for my vain vile desires, so that I was able to wander along on it guided unimpeded to my corruption and was therefore unable to perceive, much less escape, the snares which were beginning to draw me to eternal damnation; for I lived like the rich man, and had I continued, I should have also quite rigidly died like him.

Alas! But what were these vain sensual pleasures, the presumed and yet so quickly dissipating joys, the follies of such false amusements, the fulfillment of my foolish desires and the like, compared to the heavy cares with which you tormented me day and night more than any hangman would have, not only to keep you but also to increase you, so that I should not, through your diminution or complete loss and ruin, be deprived at the same time of my great esteem, honor, and reputation, of my magnificent soft life, and of other things desired by and pleasing to man's senses which I imagined I was enjoying so superabundantly solely because of you, and feared I should lose, were I to lose you.

But I must say once more: ye accursed riches, with all this you were by no means satisfied! Hitherto it had been mere child's play and for me a pleasant sweet poison by means of which you led me by means of my good contentment, without my noticing it, on a seemingly merry path straight toward damnation (a path which, to be sure, now that my eyes have been opened, I cannot with good common sense call merry because of the bitterness mixed with it).

At last, however, ye treacherous riches wished to deal me a blow to the heart with violent tyranny and most extreme torture, for look you, after the hurdy-gurdy girl had successfully perpetrated her theft 
and my treasure had flown away, along with my wealth, these evils with which you plague people who possess you should have ceased also. But alas! Then you really did let me feel for the first time the torment of hell itself. Yes, I am more than glad to confess that at that time it would have been touch and go, and very nearly over with me and my soul's salvation, had the mercifulness of the Almighty, through His angel, not preserved me, so very short was the step between me and total despair. For just as theretofore the care to retain and to increase what was mine had tormented me, now it pained me all the more because it was kaput and there was no hope of getting it back again.

I no longer had a moment's peace anywhere, no peace came to my soul and no sleep to my eyes; in summa, outwardly and inwardly I was thoroughly in nature like one who is in love with a maiden and despairs of her requiting all of her love. And I cannot better liken any madness of that time to any other folly than to precisely that into which foolish lovers sink; for I walked, ran, and made many a useless trip. I went with Saul to Endor, and sent with Ahaziah to Ekron. No exorcist did I fail to visit, no warlock to ask, but all in vain! No encouragement from relatives had any effect on me, no consolation from the clergy was of any help to me, nor did I take to heart at all their warnings and admonitions. I could do nothing more than sigh, and yet what pained me most of all was that here were people whom I had really never insulted, but rather had shown every kindness, who were happy at my misfortune and to see me going about so downcast and humiliated; for I became lean of body, dull and incompetent of mind, weak in strength, pale in color, melancholy in humor, and in a word, quite as wretched as the above mentioned unrequited lovers are wont to be.

Alas! Great fool that I was! What were my only thoughts? After all, I still had about as much wealth, even though it was not in cash 
money or as much gold and silver, as I had lost, and in the bargain my credit was still good with everyone, not to mention my considerable number of friends who did not forsake me, so that I might, better than many others were able to, not only bring myself through this crisis with humor but also garner and win back again a stately sum. But of what help was that? My folly must needs go to its extreme, so that I might learn, painfully indeed, what other people saw anyway by looking at me; namely that I, contrary to all that is reasonable and fair, loved gold more than God. 


\section{Chapter Two}

\section{Portrait of the Magician}

In the midst of this, my misery and wretched state, I was walking disgruntled and in the very greatest sadness at the time when it was just coming towards the end of August, into my large garden which I had right outside the city gate; and if anyone who saw me strolling along this way had at that time been able to observe and see my great affliction of heart as well as the external appearance, which is commonly wont to agree with the inner condition, he should without doubt have concluded that I was about to hang myself, as the Chinese do, on a tree. But it turned out, praise God, better: for this was the very place where I received my first consolation, which I drew, by means of divine grace, from my own reason; namely when I considered in what fashion the crown-flowers, tulips, narcissuses, hyacinths, and other flower-bulbs were completely bereft of their beautiful embellishments, but were for all that not ruined at all, but rather lay quite fresh in the earth in the firm hope that in the coming spring they will sparkle anew again in their usual raiment. You fool, I said to myself then, if you have no reason, as a sensible person should have, and if you're lacking in wisdom and knowledge, then do learn here from these mute plants. Who knows how God, who after all has never yet denied you any good fortune, has decided to bless you again? You do, after all, still have in your hands the seed, that is the means and opportunity to plant and to harvest, just as these flower-bulbs have the nature of their growth, greater riches and treasures than you have lost. To put it briefly, my consolation, hope and good resolve abruptly became so mighty, powerful, and great that I 
imagined that only now had I turned from a blind man into one who can see, from a Cyclops into an Argo. Therefore I scolded myself for having acted so foolishly over my loss, for having tormented away my life myself by nearly more than half, and what is most abominable of all, for having sought, contrary to the express commandment of God and a pious Christian's proper behavior, aid and counsel from sieve-shakers, treasure-hunters, and exorcists. Yes, I even resolved how I should atone for this mistake, and how I intended to mend my ways if I ever became rich again; in summa summarum, I suddenly fell into such an enterprising frame of mind as I had not been in for half a year, and into such a one which a few hours ago I durst not have imagined would ever again come to me all the days of my life. And at that time I called the time lucky when I had spent perchance a dozen sovereigns for a few flower-bulbs which now, in my greatest affliction, caused me to take a path to which the encouragement of neither my clerical nor lay friends had been able to bring me.

After this I considered what I wished to do and how I wished to arrange my transactions so that I might again really flourish, and in these thoughts I became aware of how the concern which I had hitherto had, had made me incapable of all the business dealings which prosperity requires, and what I had since then neglected; therefore I resolved henceforth to mind my house differently and to earn back everything twice as much as I had frittered away, and deep in these thoughts went back out of the garden again as cheerful as I had before been grieved and depressed when I went in, in order to forthwith go home, look to what was mine, and make a good beginning at what I had resolved to do.

But! But! How vain and void, how empty, flawed and transitory does our inconstancy make the right concepts and plans we make! 'Tis inconstancy which commonly causes us not only often not to achieve in the here and now the goods we have desired all our life 
and for which we have striven in all our actions and transactions, but also even though we have often spat on our hands and boldly set to with the ax to cut out the tree of sin within us, causes us to lose eternal life, alas, eternal life!

Dear reader, how should my resolve-which was founded only on re-acquiring money and goods, but not in the least, through love for God, on changing my life for the better-be able to prevail and bring me good fruits? But in one respect, I cannot deny Inconstancy her praise either, since she often makes disconsolate people cheerful, which I learned at that time from my own experience, when I went into the garden in despair, as it were, but, contrarily, came out again joyous because of her effect on me then, not to mention that she, like a divine power and virtue as it were, also often makes rich and eminent people of the poor and scorned, lifts up the lowly, and deposes the proud.

I cannot actually say, however, whether on this occasion the change she effected was harmful or profitable to me, for look you, as soon as I stepped out the garden door I found a stumbling block which I know not what spirit had placed on the path before me and on which the resolve I had at that time, and told of above, shattered again, namely an old, haggard, bent-over little man with tiny eyes, a tiny, pointed, hooked little nose, a large gray-black beard, pale in color and clad rather shabbily. He looked at me so sadly, pityingly, and sympathetically that I could without difficulty tell from his visage that his person must needs be something special, and that in addition to that he must needs be desirous of speaking to me also about some matter of import; therefore I was unable to go past him without uttering a friendly greeting to him.

What I had imagined to myself was indeed the case, and to be sure even more so than I might have thought of him, for after a quite short exchange of words (for one remark soon leads to another), he 
told me not only the loss which I had suffered, but also he knew how much of it the hurdy-gurdy girl had thrown away and had given to the baker boy, and he specified it as neatly as if he had robbed me himself and had counted the last coins as well as the sighs I had because of them.

Thus, this, I thought to myself, is the man for you, as I was astonished with wonderment, as it were, at his tale. I thought to myself: if you know this, then you know more. I therefore asked him whether it might not be possible that I should be able to get back again what was mine. "Surely," he answered, "that can well be, provided the gentleman will trust and follow me, but on the condition that since the thief robbed you no human being has yet seen what is left of the stolen money," which lay hidden a half hour's walk from here in the forest; and if I wished, he was prepared to go thither with me to fetch it, because anyway, now the propitious time was at hand to get hold of it, which time would soon pass away and in the future would never again be so suitable that one would be able to retrieve even the very least farthing of it.

Who was happier than I? For because this little man, before I asked anything of him, had told me the unmitigated truth, I was persuaded that he would not be lying to me now, either. In my mind I was already just as rich again as I had been before, and was so overjoyed that I knew not whether I was standing on my feet or my head, which made me much more inclined to go into the forest with him than a lusty wench might be to go to a dance; but I requested of him first that he let me go to my house in town for a moment to inform my wife of my absence so that she should not worry on my account; for because my unbearable sorrow was known to her, I feared that if she found me missing she would conclude that I had done harm to myself, and she would therefore herself jump into a well; which trip he at first did not at all wish to permit, but finally grudgingly 
granted, with the express protestation that it would not be his fault if I should let slip away the best time to get back my treasure, with the assurance that the longer I hesitated, the less of it would be allotted to me. So I went, saw to it that my wife should be safely taken care of, and consoled her with my quick return, without in my haste telling her where I was going, what I was going to do, or how soon I would be returning. After that, I returned to the above-mentioned little man, who in the meanwhile had been working for me in the garden. 



\section{Chapter Three}

For what the lost treasure was exchanged

Our accord and agreement was that I should go with this traveling scholar, as he called himself, and wished to be called, into the forest to that spot where what was left of my lost goods lay hidden; there I was to receive them again, unless my wishes should be otherwise, and should give him for his pains what I myself wished to.

Now after we came into the beginning of this same forest, he made with his staff a double ring on the ground and two strange characters round about it, put me, along with himself, inside it and mumbled out some words which were such gibberish that I was not able to understand a one of them; soon thereafter a serpent of frightening form, but of lovely colors, appeared outside the circle. It was of terrible size and had as it were the visage of the most extremely beautiful maiden, two feet in front such as one paints on griffins, and on its back two wings such as bats have, but without their looking so repugnantly black, but rather rosy red, and set here and there with many eyes, just as on a peacock's tail; its body was covered all over with gold and silver scales, so that it appeared as if it were covered with naught but brand new coins made of the two afore-mentioned metals; on its head it was crowned with a diadem made of all sorts of precious jewels, the tail, however, which was rather long, well colored, and delicately ringed, ended in a frightful fiery flame which seemed to me to be of terrible heat, because without surcease sparks of fire flew out of it as frequently and quickly as if Vulcanus, Sterops, and Brontes were forging with might and main a most brightly glowing piece of iron on their anvil with many heavy hammers. This 
frightful sight caused me many millions, yes untold more millions of terrible fear and pain than the lovely visage of the monstrum had in the beginning pleased me; for just as this serpent's entire body was pleasant, lovely, and delightful to behold, its tail, on the other hand, was all the more many thousands, thousands and thousands times more repugnant and ugly.

It asked the traveling scholar what his desire was, saying that he had demanded she come into this forest, after she first had set her blue-glazed feet on the outermost edge of the circle; he answered: "I desire to hear whether and where this man present here and deprived of what was his may attain again his lost property in this forest."

She said thereupon that most of what was left from what had been lost was still to be found at the spot where the thief had hidden it, and was easy to get, provided no one else espied it before our arrival there to thwart our recovery of it; but nevertheless, let Fortuna decide this game as she wished, there would nevertheless be such a precious jewel to be obtained instead of the lost treasure that it might well not be bought for all the gold taken from the victim of the theft, nor all the worthy goods which he still possessed; with which jewel I should find myself well content, should it be bestowed upon me.

The traveling scholar hereupon wished to force the serpent with conjuration to reveal both the hidden treasure and also the way to it, but it answered that it was compelled by a higher power to bend to Fortuna who had already made her decision now and had set out in haste to enrich another man; and when the traveling scholar was unwilling to forbear to continue with his conjuring constraint, it behaved so violently and terribly that I was happy that he gave it leave to depart. Straightway thereafter it was fettered and led away by a naked maiden whose figure we often see depicted by painters as standing on a winged globe and with a sail in its hands. 
Therefore the fellow made another circle, stepped into it with me, and thereupon conjured another spirit, which he asked what the virtue and effect of the jewel was which was to be obtained instead of my lost property. He received as an answer that it had the power to make him who had it with him invisible, and it was already to be found in an anthill, and, to be sure, very close to where what I had lost had been hidden, which anthill the conjured spirit, so that he, the conjurer, might readily find it upon his arrival, would mark with a tongue of fire above it which no one save us two would be able to see, but, so that we might without fail find it, he would permit us to be accompanied thither and shown the way by underlings under his command.

Finally the spirit revealed to the traveling scholar also, because they were on especially familiar terms with one another, that in just this way my property had been taken from me by a woman that had robbed me when she was invisible.

After that the traveling scholar erased again the ring he had made, after first he had dismissed the spirit again or had got rid of it. As soon as this occurred, there surrounded us a large horde of wolves which at first enclosed us from behind in crescent-moon fashion, just as the Turks are wont to make their battle order, but finally found a ring almost completely around us save for a gap toward which we walked, while they, the wolves or spirit in wolves' shapes, left it open to this end in the circle around us till we finally came to the anthill and saw the afore-mentioned tongue of fire flickering merrily over it.

There we sat down, whereupon the afore-mentioned flame instantly went out; the old man, however, said to me: "Well, good sir, here is the place where you will take possession either of your treasure and lost money or of the means to make yourself invisible; choose quickly one way or the other, before the hour of fortune slips away completely, to obtain the one or the other." 
I thought of this and said to myself: According to the report of the serpent which appeared and was placed under duress, 'tis doubtful whether you will get back your lost treasure or not. Who knows whether perhaps someone has already seen it and taken it away? Moreover, you will know how a large number of sovereigns were thrown down onto the public market place amongst the folk! So who knows how little might still be left of that which is supposed to lie hidden here, and whether, be the treasure ever so large, it should be chosen over the art of making oneself invisible, which rare art I have long and often wished to possess anyway. I therefore said to the traveling scholar: "Of goods and gold I still have more, therefore I shall indeed renounce and forego what was lost and hidden here and reckon it to those treasures which also lie hidden elsewhere here and there. Whoever finds it, as much as I might think I have a right to it, as far as I am concerned, and with my consent, may keep it for his own, but with this reservation: that I retain the jewel with which I can make myself invisible and which I am willing to accept in lieu of my lost treasure."

Thereupon both of us sat down by the anthill, of which the itinerant scholar took a handful and asked me whether I saw him. I answered "Yes!" He, however, seized another handful after he had put the previous one aside, and asked me again as before whether I still saw him, and proceeded so long in this fashion till he seized a handful, through the power and effect of which he disappeared from me in a trice. Nevertheless he kept sitting on his former spot and asked me as before whether I saw him, which seemed to me exceeding wonderful and frightful, especially because I heard him so close to me and yet did not see him; now when I told him that I did not see him, he said: "Then hold up your handkerchief and receive what you desire to have and in the stead of your lost property." I did it and thus received the makings of the nest from the anthill, 
whereupon I instantly saw the old man again. He commanded me to tie up the handkerchief carefully so that the thing, which was among the matter carried together by the ants and perhaps, consisted only of a simple tiny little stone or root would not be lost. I obeyed with the greatest care and attentiveness, so that not a single grain of it got away, but meanwhile paid heed to see whether the itinerant scholar was looking me in the eye when he spoke with me, or at my hands when I bound up the handkerchief; for had I remarked anything of the sort about him, I should have straightway concluded that he, as a magician, might have made himself invisible by some other means, and have it in mind to pay me off for my treasure, which I had renounced, with this useless nest material so as to then recover and retain the treasure for himself alone. But after I was not able to remark about him the least thing of this sort, I quite changed my mind and was much more content than if I had been given I know not what other sort of great thing.

Afterwards we tested repeatedly the effect of my handkerchief, for the itinerant scholar easily discerned what my suspicions were; therefore he gave me myself cause to assure myself for certain and to make me believe firmly by repeating the experience often before my own eyes; and what made this certain was that I was unable to see the handkerchief itself but was easily able to seize it when I put it down anywhere.

Now when I had in this fashion become certain about this matter, the itinerant scholar took leave of me, not knowing whether in this hour of good fortune, as he called it, he had received or not any of my treasure, over which I had granted anyone who found it complete power and sufficient rights of ownership. 



\section{Chapter Four}

A very serious case of spooning, in fact, nearly two of them

No one can believe or imagine to himself what strange and odd crotchets and plans I had on the way as I walked homeward, in how many ways and how many places, namely, I wished to make my invisibility profitable to me. There, with my thoughts, I was already invisibly present personally at the conferences and secret negotiations of the one or the other company of most distinguished merchants, and listening to what they planned in regard to trade and to wares of one kind or another, so as to make use of it for myself, and because I did deem myself not the least among the merchants of our land, to cut my sails to their wind so that I should again be wealthy, even wealthier than I had been before. To just such purposes I not only went to the meetings of our city council, but also even was party to the secret state councils and discussions of mighty potentates, so as to learn there to my advantage what was decided about war and peace and how, in accordance with these, trade and prices for wares would increase or decrease accordingly.

In such thoughts I prized myself so happy and saw my future prosperity so excellent that I myself was well nigh unable to believe that I was invisible, by which means I intended to become so happy and rich. I thought to myself often: what if, however, this necromancer perchance has done to you what the two painters in Boccaccio did to a simple-minded ninny when they persuaded him too, laden down with a heavy sack full of stones, that he was invisible, till his wife to his utter chagrin bade him welcome? Therefore I often put aside my handkerchief to make really sure of my invisibility, till 
finally I became aware that not only did the wild songbirds which I encountered on the way not shy away from me, but also that, especially when I came into town, even the people, both those whom I knew and those whom I did not, neither greeted me nor, as I had come to expect, doffed their hats to me, not to mention that no beggar demanded alms of me, from which I then became sufficiently assured that in truth no one saw me.

Therefore I went in good cheer first of all to my house, mainly to see how my servants were behaving in my absence. My dear little wife I found, to my way of thinking, far more disconsolate than I had ever in all my life seen her, especially since she without surcease heaved one sigh after the other, from which anyone could discern without difficulty the magnitude of her concern; and because I could imagine naught but that she was without doubt both worried about my former concern and anxious because of my absence, I took this to be a certain and infallible sign of her heartfelt love for me, which pleased me not a little; indeed so refreshed me that I thought I now had received sufficient amusement from what was tied up in my handkerchief to make up for my lost money; and even if someone at that time had wished to give me even as much for it as I had lost, I should not have exchanged it with anyone. Now just as it tickled me excellently that my wife loved me so much, on the other hand I also had great sympathy with the attested anxiety with which she was obliged to be patient on my account because of this love, so that I should have really let myself be seen by her, both to console her and to make her happy with my presence, which she so heartily desired, had I not also wished, while invisible, to examine my servants in regard to their behavior.

To this end I sneaked around everywhere in the house and found that each was going about his business as faithfully as he had hitherto been wont to do. For nearly three hours, till on toward evening, 
I kept watch in my shop next to the money-box into which they were wont to put the daily receipts, in order to see whether my shopclerks, of whom I had three different ones, were not playing me false; whether in selling they were exact, in receiving money careful, and were industrious in putting the money, down to the last farthing, in its proper place, but was unable to detect the slightest thing which should move me to dismay, for I found them to be as I wished to have them.

And so I also lurked in the kitchen to see how things were going there, as well as in the cellar, but found in both places nothing unusual going on which might have caused me great damage, save that the housekeeper filled for herself as well as for the cook a mug with my costly Neckar wine (after she had first taken a rather large swig of it) and afterwards made the keg full again by pouring table wine into it, which, to be sure, did not greatly vex me, because it did no particularly great harm to my fortune, even though it would somewhat reduce the excellent taste quality of my Neckar wine if they treated it that way many times. The cook, however, I saw put her hand in a spot the reader can easily guess in order to pursue lice, and saw her take several of them captive (some of whom she sent into exile, but some of whom she even executed), and afterwards muck about in the raw as well as the cooked foods with her unwashed hands. But how could I hold this against the poor ninny? It was, after all, in the heat of August, when these varmints plague everyone (not just the fair sex). Besides, women say, "Sausage is fattening." Also: "What you don't know can't hurt you." Nevertheless, I began to feel more like throwing up than eating as I saw her hunting and murdering, and saw how, with her fingernails still bloody, she reached into the spice-and-salt-box to make the foods more tasty.

From there I sneaked back to my beloved, whom I found in her boudoir in a much more lamentable state than the first time, for she 
was crying so that one tear followed the other, and from constantly wiping them away she had her mouchoir so drenched that you might wring it out; I had unbelievable sympathy with her delicate pale cheeks which, because of my absence, she was inundating with these tears of anguish; for in truth, were she to have known of my presence, she would probably not have either shown her heart's concern or made so open a show of it.

Finally she said with a deep sigh: "O Amor, thou grim tyrant! If there is then no other medicine or remedy to be rid of thy unbearable cruelty, unless it be that I have the beloved person himself in my arms, then I shall be obliged to make so bold as to do something which God would never bid me do!"

I thought to myself, "Now it is high time that you quickly take pity on this aggrieved soul, reveal yourself to her to her consolation, turn away her pain, rescue her from total despair, and revive her spirits with your highly pleasing presence!" And I should have straightway thrown my handkerchief aside so that she might be able to see me, had I not thought that there would be time enough for that, should she take to hand a knife or a rope to put an end to her life, especially since if she did start to do herself in, the unforeseen rescue from her direst need would make her subsequent joy many times greater.

Meanwhile the time for the evening meal arrived, the table was set, my servants assembled there, and my wife dried her eyes and cheeks, and also seemed much more cheerful than I had envisioned that she would soon be; but all the same, she did not wish to eat anything, for she was so full of sorrow that unfortunately, Lord help us, she wished nothing.

Now when I had with joy perceived the change which came over my wife and judged from it that for the time being she was not going to hang herself on my account and that it would therefore be unnecessary for me, in order to cut her down, to stay constantly at her 
side to prevent her suicide, look you, I resolved to keep an eye on my servants and to see what they would do between supper and bedtime, for I must confess that in such matters I am rather suspicious; and, dear reader, who wouldn't be toward such people as man the plow or the oar which feeds us and who through their faithfulness and industry could soon make one rich, or, on the contrary, if they are rapscallions through wasteful negligence, laziness, and unfaithfulness could quickly ruin one and put him in the red.

Therefore I looked in on all of them save the housekeeper, who generally had to work every twenty-four hours till eleven o'clock at night till she had done all her duties and arranged one thing and the other for the next day; for she was quite industrious, the last one in bed and the first one up out of it early in the morning, and therefore the watchful eye of my household, or the pole star by which the rest of the servants were obliged to set their course. She, however, had a position of so much trust because she was my wife's cousin, since she was related to her in about the thirty-second or third degree. And for that very reason it was necessary for me to pay the closest heed to her on whom, as it were, all the prosperity of my family depended; for I thought to myself: if this watchful Martha and busy overseer of my house is faithful, then all the other servants cannot but cooperate in furthering your prosperity.

She acted in a way I was glad to see, and therefore I was quite willing to overlook the fact that she was on such intimate terms with my Neckar wine. After she was about to go to bed, however, and I had sneaked after her (especially since heretofore I had suspected that my middle clerk had become smitten with her, and also because I could not believe either that so rare a beauty as she was possessed of could live without carnal love, that is without suitors and the prickings of her own flesh), look you, there stood my aforementioned clerk in her way (whom I had found begging and taken in because of his 
good figure and physiognomy, in the hopes of having something decent in him) and was waiting for her. He was not, to be sure, going in white, as those ghosts are wont to appear in houses of whom it is said that when they walk abroad it means that the housemaids will get fat bellies, but rather he was clad and dressed up as if he had intended to stroll about like a dandy in town on a holiday; in addition, he was armed with his sword at his side and had on his deer-leather winterball gloves, just as if he had intended to fight in single combat with a dueler. I could not imagine what this attire and his presumable going out at night might mean, but I imagined to myself that he might be intending to go somewhere either with companions to a feast or to the light of his life, in which case my purse must needs do well by him, because he himself had no money, and even save his fine garments had nothing else in wages from me. But before I, in order to fathom his intent, was able to trouble myself with further reflection, my cousin, the housekeeper, asked him where he thought to go so late, since he knew that she had locked up the house and he would not be able to get out of it unless he had a skeleton key to open it with, which she sincerely thought was not the case.

“'Tis you! 'Tis you! Abode of my life! on which my mind, soul, and even the decision either to live or die depends!" he answered. "O God forbid! What are you saying?” said my housekeeper thereupon. "How can you talk so strangely? God gave you life, that I shall not take from you. Go instead to your bed and leave off this foolishness, or I swear to you, should you make so bold as to touch me in the least, I shall raise such a cry that you shall clap your hands over your head at it. How dare you presume to dream of defiling your master's house in the person of his cousin, your master who, after all, has overwhelmed you with so many kindnesses? I shall spare you because you are his servant whom he loves; else I should shortly bring it to pass that he chase you off again despite St. Valentine, whereas 
contrarily the continuation of your good behavior in his house may bring to you great good fortune and honor? So act sensibly and consider a moment what you are doing!"

"The devil take me, body and soul" (may God protect me and the dear reader), he answered, "should I find that I am not to partake of your love, if I do not immediately, look you here (whereupon he gripped his sword by the handle) plunge this cold steel forthwith into my heart, which is indeed consumed by the flames of love, and thereby deprive you of your most faithful lover and at the same time my body of its life."

Thereupon he drew from its sheath his cruel frog-sticker, his bloodthirsty sword I meant to say, which I rightly call cruel because it was not willing to spare its own master's life, and therewith assumed a posture, as Saul may perchance have stood when he fell on his own sword. Now as I stood there, and the housekeeper, however, started to speak to prevent this pitiable suicide, my wife gave a signal with her little bell, which meant that the housekeeper should come to her immediately. She obeyed quickly, and I followed, tiptoeing after her, both of us leaving the enamored fool in his fit, whether he might do away with himself or not. 



\section{Chapter Five}

The invisible man sees the groundwork laid to a structure with which horns were to be placed on his head

The housekeeper went to my wife in her boudoir, and I slipped in after her. To her my wife gave a sealed little letter with instructions to take it early in the morning at daybreak to her cousin the apothecary and to learn where she should go to fetch the wares ordered in the note. She accepted both the note and the command obediently, as was her duty, but hesitated to go off with it straightway, for which reason my wife bade her to do so. But she was loath to and said: "Dear sweet cousin, forgive me if I have reservations, for the preservation of my honor, about obeying you now as a servant should; for our Freddie (that was the name of my middle clerk) was lying in wait for me just now on the way when I was about to go to bed, and, with the threat to do away with himself should I not follow him, imputed to me things which neither he nor I have the right to do. I believe too that had our Lord God not put it in your mind to ring for me, I know not what sort of misfortune might perchance have occurred." My curious wife thereupon wished to know in detail the entire sequence of events, which the housekeeper indeed quite candidly told her; she, however, thereupon answered: “'Tis true enough that no person who has not yet experienced it can believe how miserably love torments one; but nevertheless, the wanton lickspittle should keep a better hold on himself, and in a house into which he was taken out of pity should think better of making so bold as to behave so outrageously toward a cousin of the house. I must confess, dear cousin, that I too am enamored unto death and hardly know how to bear such pangs of love during the absence of my husband." Upon ending these 
words she thereupon again began to weep, so that it must move, if not the housekeeper's heart, then at least a heart of stone to take pity upon this woman in love. Meanwhile I saw the draft of the note to the apothecary lying on my wife's table; it read verbatim as follows:

Most honored and appropriately heartfelt beloved cousin, etc. You know without my further reminding you in what miserable melancholy my most beloved husband has passed his days since we lost our money, which so pains me, as his closest relative, indeed as his body's most faithful rib, that in the long run I fear I cannot bear it; for which reason then, instead of sleeping, I torment myself with musing about whether no expedient may be found to cure this illness of his, whereupon it then occurred to me, the best medicine would be if you, cousin, would prepare for me along with a good piece of marchpane a few dozen macaroons, some with citronate in them and others with the sort of things which strengthen the heart, and mix them with strong substances which are so constituted as to not only dispel the harmful melancholy humors and purify the ill blood, but also to arouse a natural desire, and I am sure you will well understand me. I shall then give him this confection, which he loves anyway, and through amiability first get his mind off his lost money and onto me, and thus expeditiously bring him back to his senses again so that little by little he can put his hand to his trade as heretofore and gradually forget about what he has lost. But your advice, dear cousin, which shall remain between us, and your dexterity, which I shall trust, will be best. With kindest regards as ever, etc.

All the while I was reading this, the housekeeper was saying to my wife to console her: "O, cousin, what cause have you to weep? 
Can you not bear to be separated from your dear husband this one night?" "What?" said my wife thereupon, "this one night? You may believe for sure that he has scarcely touched me for longer than four weeks now! He lies the whole night and can do naught but sigh for his lost money; from which I must needs deduce that he loves it more than me. He is worrying himself sick and so weakening his strength that in the future he'll make himself quite incompetent to perform a man's chore as a man should. What do you think, dear cousin, what sort of pleasure does a poor wife like me have from such a wooden lord 'n master?" The housekeeper answered: "As one who as yet knows nothing of menfolk, I know, to be sure, nothing to contradict what you say, but it seems to me your husband is such an upright, esteemed, and friendly gentleman that if a man like him were to be granted me, I should not exchange him for any other man in the entire world, much less wish to do so." "Yes, dear little cousin," said my wife thereupon, "before when I was still in your condition, I thought the same way you do; but back then my husband was a completely different fellow than he is now. Back then he loved me more than all the business in the entire world; but now he sighs only for his lost money, which can't be gotten back with sighs after all, and puts his wife out to pasture. About Freddie, don't you worry at all, and consider it a fairy tale when he says he is going to do away with himself unless you accommodate yourself to his desires. 'Tis the plain truth and nothing new at all when these wanton birds act that way, first to make us poor stupid simple women full of fear and sympathy and in the end to make off with our maidenheads, as unfortunately, already many a maid who let herself be moved to pity that way, with irretrievable damage and loss of her most precious jewel, namely her virginity, has learned. Just think naught else but that that bird (without having done any harm to himself, or even having ever had it in mind to do any) is now lying in his bed again and thinking up new 
traps to set so that in the future he may delude the game which this time, contrary to his hopes, escaped him. And even if such a lewd stud were as earnest as he pretends to be, so that he actually did what he threatened to, it would still be better and more responsible for a maiden if she let such a fool, if that is what he wished, go to the devil alone than for her to embark on a path on which (not to mention the shame which she may perchance expect in the here and now) she will play the role of his companion on that journey."

It is said of the women of Holland that they (particularly in the trade dealings of merchants) are much slyer, cleverer, and cannier than men in many other places are; but I can assure you that I found my wife much craftier and more cunning than the women of Holland could ever be. Just hear how the malicious beast so nicely shuffled her cards.

She had in her boudoir a bed barely big enough for two people on which she often was wont to spend the day lolling about and in which she slept at night when I was not home. She bade the housekeeper lie down in it, although she said that she took it to be certain that on the way to her own bed she would have nothing more to fear from Freddie this night; and thereupon she began in earnest to discourse with her about the cruel and unbearable passion of love and to paint it so nicely for her that it seemed as if she had been studying naught but this all her livelong days; and after she thought that through wide-ranging digressions and solid reasons she had now made the housekeeper sufficiently amenable to her purpose, she reported to her in what measure she had for a long time now been enamored of a studiosus who the past week had been awarded the degree of doctor of medicine ( $O$ mirum! How I felt in my heart when I heard that!), which scholar she would never again be able to banish from her mind, even if she were to carry the memory of him to her grave; thereupon, amidst pleas, tears, and sighs, she made her unbelievable 
promises if she would keep this love of hers a secret and be of assistance to her so that she might enjoy her beloved doctor.

I must confess that the housekeeper resisted for a long time before she was able to resolve to let herself be used for this purpose, till she was finally won over by both pleas and promises and let herself be persuaded to promise to be faithful and obedient to her in this business; thereupon she told her that in the note to the apothecary she had ordered some confections which she was to take tomorrow to the doctor, because it was his name day, and present to him in her name; also, tomorrow morning she was to dress a pair of fat Geneva capons and from the one have the cook prepare a pie with rosewater, little raisins, and other spices, and have the other one stuffed and roasted. After that she wrote a little letter to the doctor with the following content:

My most revered doctor and even more, my dear friend, beloved from the bottom of my heart:

The ever-present thought of the hope, which your good reason and excellence has aroused in me, to enjoy at some time in the future your well-known expertise in medicine reminded me that this day is dedicated to your dear name, on which day one friend is ever wont to confirm his friendship for the other with a gift, and to express the heartfelt wish that he live happily to see many more such days, which custom I too wish to observe in accordance with your merits, and herewith fulfill my obligation from the bottom of my heart, with the humble request that you accept the accompanying collation in the spirit in which it was sent you and thus enjoy it for my sake. Even though my husband is not home now and it is therefore unseemly of me to invite strange men into my abode, an indisposition I am now suffering nonetheless requires the kind of cure for which I should be loath to 
dispense with the assistance and medicine of my deeply darling beloved doctor and therefore request in the most friendly way that you be so kind as to betake yourself to me after sundown. In expectation of your arrival, which will bring me such joy I remain ever

My darling beloved doctor's faithful servant. N.N.

Date: August 25th etc.

Now even though in this note my lewd wife did not announce in detail where the shoe was pinching her, nevertheless the doctor, were such a note to come to him, would easily have been able to grasp it, unless he were a eunuch or even a fool, and not a doctor. After concluding and sealing it, she also lay down beside the housekeeper and instructed her further as to how she was to behave tomorrow on her embassade, and in conclusion she took her in her arms, hugged her, and said: "Tomorrow at this time I hope, unless my husband comes home, to have the doctor in my arms like this." I however thought to myself: Just you wait till then, and I'll fix your wagon; thereupon I sat down in my easy chair in which in the summertime I was wont to sleep sitting up for an hour after dinner, and plotted there the entire night how, by thoroughly humiliating my wife (but in such fashion that no one else got wind of it) I might destroy and extinguish this new and budding love in its first glow, and before it broke out in quite inextinguishable flames; and it was indeed necessary that I do it, for I was dealing with a handsome young doctor and with the most cunning and sly wife on the entire earth, with whom artfulness was required to deceive them both. 


\section{Chapter Six}

\section{One good turn for another, and a gratuity for the maid}

I, to be sure, had not closed an eye that entire night, and yet I was just as ready to go to the apothecary's shop as was the housekeeper, who had got her night's sleep; for the apothecary was related to me and my wife's cousin only through me; moreover, he had forever and always been my trusted bosom friend and my schoolmate since childhood, so that I could think of no one better than him to be more loyal to me than to my wife (whom I on this occasion wished to betray with his help) in this matter in which I could not well dispense with his services.

At that time I saw the housekeeper naked and found her to be so lovely, so beautiful, so attractive, and so well proportioned and shapely that I could not blame Freddie for losing his heart to her; but I thought that despite this I should not let this sweet morsel come to him untasted, for I straightway decided to avenge my wife's infidelity, which, to be sure, she only had in mind, by really doing to the housekeeper what my wife planned to let the doctor do to her, even though otherwise I had always been faithful to my afore-mentioned wife and had never in all my livelong days had in mind showing her such infidelity either.

But who else was responsible for this but my beautiful wife, who had tempted me, as it were, by exhibiting this beautiful woman to me, and without doubt had gotten the good maiden hot and bothered with her discourse about adultery and her own first steps to actually commit it? I went out of my wife's boudoir with her and watched with pleasure as she wrung the capons' necks, looking forward to 
how we were going to devour them so merrily with one another. Now before she gave the cook orders about what she should do with them and get ready to go to the apothecary's shop, I preceded her and arrived just as the apothecary's clerks were opening the apothecary's shop and were busy setting the decorations on the counters. I, to be sure, came into the house invisibly, but after I had seen a corner where I was sure that my handkerchief, together with its invisibility, would lie in safety, I put it down, let myself be seen, and asked for the master of the house; he was still in bed sound asleep.

Because I was wont to take more liberties in this place because of the intimacy between the apothecary and me than if I had grown up in the house, I woke him up, took him to his upper chamber, and recounted to him all the dealings of my wife. I kept nothing from him save alone this: that I was able to make myself invisible; indeed, I even confided to him the plan I had in mind, not only to thwart my wife nicely through deceit, but also to repay her with another woman for the infidelity which she had resolved to show me. Now that was just his cup of tea, for he was the sort of fellow whose heart leaped for joy when he was able to help someone carry out something of this sort.

The first thing that he did was to command his servants to keep my presence secret; after that he had almonds made into the marchpane which my wife was going to order; of biscuits, macaroons, Nuremberg Lebkuchen, and the like, he had enough on hand anyway. But for my wife's pleasure, to give her in the bargain, he made a dozen macaroons which he mixed excellently with saltpeter such as should be suitable for cooling her heated kidneys. Everyone in the apothecary shop was obliged to work, so that my wife should not be hindered from honoring us with a fine feast; the marchpane he decorated all over with flaming hearts with an arrow through them, with 
clasped hands, and the sort of fantasies which lovers wear on their escutcheons. The verses around the edge were as follows:

My love for you

Each day blooms new.

And during this labor he and I waited for the housekeeper with great longing.

She finally came, an hour or an hour and a half after me, with the note pinned to her. But alas, what a misfortune! In her haste the poor thing had snatched up the wrong one, namely the one on which was written "To be delivered by hand to Doctor Louis Adolphi." The apothecary, who was a sly rogue, said: "Just come right in with me, miss," and meanwhile broke open the note as if in haste as it were, but so that he did not damage the seal, despite the fact that he well knew in advance and had learned from me what was in it. Now when he had led the bearer of the note off to the side away from his servants and was about to begin reading the letter, he said: "'Odds blood, miss, what have you done? I thought you had a note to give to me, but I well see that it was meant for a doctor. What shall we do? It's been opened now!" At that my housekeeper became quite flustered and as red all over as a glowing coal. "Now, now, miss," said the apothecary, "You mustn't he so frightened: if you also have one for me, just give it here. I'll be sure that I seal the one to the doctor again so that he shan't notice it." Thereupon she pulled out of her bag the one written to him; he however, said to her, "So that you, miss, may see that I have no desire to know your mistress' secrets, come upstairs with me and observe that I'll not even read it, but seal it up again so that you'll be out of danger on that score." And so he brought her to me in the upper chamber.

You can well imagine how frightened the good wench was when she unexpectedly saw me standing before her, and at the same time 
the apothecary holding the two notes in his hands. The latter threw them on the table and said: "Look you, wench. There is your master; you can come to terms with him; I have other things to do." And with that he went out of the chamber, locked the door behind him, and stuck the key in his pocket.

I know not who of us two at the beginning had the most to do with the other, she with me in begging me to pardon her, or I with her in consoling her. But after she had gotten her wits back together a little, I held up to her both my wife's and her own crime, and put it to her that the former should have been punished with death, and her own with at least a public flogging; but, if I were to take into consideration the effect of love, then I should be able to forgive them both; thereupon I told her a whole wagonload of lies about how much I had long been passionately enamored of her, the housekeeper, and yet had concealed my pangs of love and, for the sake of my wife's honor, love, and fidelity, had borne them with wretched patience. But now that I had caught her with her hand in another's pocket and saw with my own eyes that she wished to reward my fidelity with infidelity and wished to kick over the traces, then it was to be hoped that it would not be held against me if I were to give full rein to my desires and pay my wife in her own coin. I thereupon approached her too with such charming gestures as the nature of my situation at that time demanded, and charmed her with such great promises, namely that in the future I intended to keep her alone for my most dearly beloved, before all other women in the entire world, and should in time care for her as befitted my great wealth, till finally she yielded to my kisses and said: "I well see that my maidenhead is predestined to be lost in these twenty-four hours. From one who intended to do away with himself on my account I saved it only last night, but now it will be lost because of my own oversight. But I should rather grant 
it to such a man as you are, cousin, than to a wanton deceiver who is unworthy of it."

In such fashion I obtained what I desired, and did to my wife what she had in mind to do to me. But what indeed do you think the great Judge will say to this on the great day? To this you will say with better reasons than the high priests in Jerusalem said to Judas (Matt 27:4) "See thou to that!" This was the least fruit of my invisibility; afterwards there came far more terrible exploits, so that of me the saying was indeed true:

The longer I act thus, the deeper I fall,

Till there is in me no goodness at all.

But that is just the way it is when, because of accursed goods and gold, one forgets God and His word, not to mention when one uses magicians' help to obtain them. I thought at the time when I brought this innocent, simple-minded, and pious lamb to a fall that I had arranged everything well and had taken fine revenge on my wife, the wretched instrument; but had I obeyed the divine injunctions of my good angel in the garden when I was observing the flower-bulbs in the earth stripped of their embellishment, I should have acted in a wiser and more Christian manner, and 'twould nevermore have gone so far with either me or my wife, much less with this poor maiden; had I left the itinerant scholar to practice his magic as long as he wished without me, then I should not have become, in setting out on this path of sin, an adulterer and a seducer of virgins at one and the same time.

At this time, however, I did not think so far, but was rather intent only on how I might put into effect the trick which I also wanted to play on my wife; and the while I did not forbear either to repeat several more times with my housekeeper what I had first done with her; and when she, with tears in her eyes, revealed to me her fear 
that she might as a result perchance come to number herself among the mothers, I consoled her with the advice that she should, when she remarked that to be the case, then betimes permit our Freddy to come in to play the father.

Meanwhile the apothecary had finished his marchpane that we gave to the housekeeper to take with her and instructed her how she should persuade my wife that she had been obliged to wait so long for it in order to be able to show it to her, for the apothecary had said that if that which he had just made was not pleasing to her, then because of other chores he would not be able to make any other for her before nightfall. We also gave her back the note to le Monsieur Docteur Louis sealed up to take home with her, so that, should the woman perchance ask after it, she would not fall apart as butter does in the sun, and when we thought that she would scarcely have reached my house, look you, there she came back to fetch the other confections. Now even though I thought without doubt that I had won the housekeeper over with my friendliness and considerable promises so that she could not but be loyal to me, I nevertheless gave her in addition and also for her maidenhead a half dozen ducats so that she should actually come to us with what my wife would command her to take to the doctor and should leave the rest for me to take care of. She promised to do this, and kept her promise too, since not long thereafter she came trundling into the apothecary's back garden gate, which we had left open for her to this end, laden down with a heavy basket full of delectables and a bottle full of my Neckar wine. And so everything went according to my wishes, since my wife had received at home the macaroons which had been made with saltpeter as a gift for her, and which dainties we had damaged by crumbling them here and there to this end, and had thus made unseemly for a fine present. 


\section{chapter Seven}

How one makes women a delicacy repugnant to women

Now, while my housekeeper had been away, the apothecary and I had finished in the name of the doctor the following note in reply to my wife, which the apothecary, because his handwriting and seal were unknown to my wife, had written and in good and proper amatory fashion had enveloped with silk and closed with a completely golden seal; whereupon we sat down together merrily with my new lady-love, made short shift of the capon pie together with the roast capon and the confections, and drank hearty toasts from the bottle of Neckar wine, to a happy decline of my wife's doctorly love. The note, however, went as follows:

Most noble, much honored and virtuous, most highly esteemed madame, etc.:

With what most obedient deference and respect I received your lovely little letter, the bearer of this reply has seen, but 'twill be impossible for her to describe to you, most highly esteemed madame, with what inward heartfelt joy I found myself favored and overwhelmed when I learned from it that my unworthy person had been deemed worthy to be accepted as your servant and personal physician, even though she has seen how passionately and devotedly I kissed both the dearest little letter and also, with what sweet palpitations of my heart, the little ring. I shall, however, give an oral account of this myself upon my unfailing arrival at the appointed time, and shall, I hope, at the same time show you by 
my deeds, most highly esteemed madame, how willing and anxious I am to wait most obediently upon you. But you, in keeping with your keen mind, will discern how suspicious the world today is, and how ready envious folks' poisonous tongues are not to spare innocence itself of calumny. Now, so that, in this instance, we both may avoid all danger, I beg you most humbly, highly esteemed madame, to be so kind as to arrange it so that there is no light on hand anywhere upon my arrival and departure for home, since otherwise I should be loath to betake myself to you at night, and especially because my art is so reliable that it is well able to dispense with it anyway, since I, without boasting, can report that by merely feeling the pulse I know how to detect more, judge, and prescribe suitable medicine than many another who must needs judge from a patient's color and other circumstances. Finally, I wish the dear sun a speedier dispatch on this occasion than is its usual one, so as to thank you all the sooner, most honored milady, for your generous present, and at the same time to appear in person with pleasant demonstrations of my obedience, till which time I am

\section{My most highly esteemed lady's \\ Most faithful servant \\ D. Ludovicus Adolphi}

Now, when it seemed to me to be the proper time, I sent my housekeeper home with her empty basket, and this note, and gave her another ducat to show to my wife and to persuade her that the doctor had compelled her, as it were, to accept it as a gift, and had said in so doing that he had never in his livelong days so enjoyed being remembered on his name day; therefore it was only right that 
she be given an honest messenger's wages. I also instructed her in yet many other things, such as lies she was to tell my wife about the doctor's desire for her; especially, that she make absolutely sure that upon my arrival there be no light at hand; and told her too how she was then to believe in other regards, even when I was about to go away again. Now, only when she was about to part from me did she recall that my wife had given her a ring to deliver to the doctor along with the victuals, which ring she therewith put at my disposal. Now it was a ruby worth about six Imperial sovereigns, and I should have gladly permitted my new lady-love to keep it, had it not straightway occurred to me to give my wife a black eye with it, which plan I also confided to my new darling, the housekeeper, in order, in so doing, to excuse myself to her; with which plan she seemed better satisfied than had I permitted her to keep the ring for herself.

That same afternoon what I did was this: first, I had myself barbered so that I might resemble the doctor, who looked quite the swain, if not completely by day, at least by night somewhat around about the mouth; secondly, I secretly procured, through the apothecary's servants, a doctor's robe, so as to wait upon my wife in it in the place of the doctor; thirdly, the apothecary was obliged to prepare for me a harmless little liquid purgative, which, to be sure, I had less need of than a sound man has of a crutch; fourthly, I persuaded him to give a banquet in his house the following day at my expense and to invite to it as guests both the doctor and me and my wife. To this end I drafted for him the following letter to the doctor, which the apothecary afterwards copied and forthwith sent off to him together with the ring which my wife had wished to send to him (since I gave it to him for this purpose): 
Noble and most learned doctor:

In consideration of the fact that even and always apothecaries have held it to be their duty humbly to lend a helping hand to doctors of medicine, their greatest patrons and supporters, by displaying the highest respect for their office and showing them every consideration, I have made so bold as to also humbly initiate herewith official relations with Your Excellency, and to heartily wish Your Excellency, in light of the professional title and dignity recently conferred upon you, all good fortune, health, and even all the prosperity and welfare you desire, and further, to present to you in remembrance of your name day today the enclosed memorial ring, with the most humble request that Your Excellency be so magnanimous as to be, and remain in the future, the esteemed patron of my unworthy person, the least of your servants, and take the trouble tomorrow forenoon to inspect my apothecary shop, and to magnanimously correct, by means of your revered wisdom, esteemed advice and instruction, whatever defects and shortcomings may be found there, and to do me the honor of being my cherished guest at the subsequent noonday meal of roast and whatever else kitchen and cellar can provide; which hoped-for great courtesy from Your Excellency I for my part humbly and throughout all the days of my life shall be at pains to deserve, since I have once and for all firmly decided and resolved to be and to remain, as long as I live,

Your Excellency's:

Faithful and obedient servant

N.N. Apothecary of the Silver Unicorn 
"Odds bodkins, cousin," said the apothecary first off, "you've gone much too far, and the doctor will think I am a fool." "No, no," said I, "the madder the brewing, the better the beer. The little ring will take care of everything and put you in the doctor's good graces. Just let matters take their course, especially since the ring seems to be predestined to be a present for the doctor; accordingly 'tis better and more pleasing to me that you, cousin, get a few prescriptions sent to your shop because of it than that I receive a pair of horns in return for it, which would without doubt be the case, should it come to him from my wife's hands." But so that my wife might proceed with her plan all the more surely and confidently, I hired a fellow who in return for a small gratuity went to my house and persuaded her that he had encountered me at N., three miles from there, where I had commanded him to wish her good day from me and to tell her that she should not worry that I had not come home the night before; some business had come up, because of which I might not be coming home before tomorrow.

Now, when evening drew nigh, I put on my borrowed doctor's robe and prettified myself as much as possible, and whereas I rubbed my outside with civet and all manner of precious balms, so that I smelled as if half the apothecary shop were marching along with me. I further swallowed the above-mentioned liquid purgative in order to transform this pleasing odor, to honor and please my wife, into the worst possible stench.

Thus outfitted I came to my house, and at the appointed time found not only the door open, but also my beloved heart's darling standing behind it in the dark, as I desired. She bade me a friendly welcome, as can easily be supposed, and in so doing pressed my hand in such measure that even a dolt would have remarked what illness she wished to be cured of. I was quick to respond to this mute 
language, and we understood one another so well that we fell to kissing sooner than to words, as it were; in short, we exchanged otherwise few compliments with one another, rather she led me into a chamber which she had prepared for this purpose on the ground floor so that His Excellency need not climb any stairs in the dark; there she helped me undress and served me better than I dared all my days hope of her or ever expect of her.

One can well imagine that we straightway thereafter went to bed with one another. I, to be sure, had put in a rather hard day's work that day, but there was nevertheless sufficient powers still left so that I was able to graze on my own meadow; I know not whether they were strengthened by my wife's extraordinary friendliness or by the magnificent odor of the civet and balm, or because the apothecary had perchance mixed a little aphrodisiac in with my purgative, which, however, the rapscallion was never willing to admit to me.

But my wife's joy unfortunately did not last long! For after this cohabitation the little drink I had taken began to rumble in my stomach, and I tossed and turned and acted as if I must needs die of the unbearable pain. I bewailed my misfortune and lamented in particular that this had struck me just now at such an unfortunate time in which I had expected to have joy and delight, and as I tossed back and forth, now stretching out full length, now curling up again like a worm, she did not forbear to console me most sweetly amidst tears and sighs. And I cannot believe that more sympathetic words could be devised and uttered so movingly by a compassionate soul than my wife uttered then. I, however, continued to play my role, with woe-is-mes and whimpers, till the medicine was ready to work and made pretensions of exiting by force; then I was able at one turn to twist, curl, and direct myself so nicely that my gun came to be pointed directly at her face; then I pulled the trigger with terrible violence, and during the ensuing salvo was able to point and to turn 
the firearm in such a way that neither her face, neck, breasts, nor belly remained unsoiled. But with that my wailing still did not stop; rather, after I had fired on her a few more times, I whisked out of the bed and began to lament again anew, and told her bluntly that she was an adulterous whore and without doubt also a witch, who had invited me here to take my life, and finally I took her by the forelock and hammered her visage wretchedly with my fists till I myself thought that for the time being it was enough; she, however, suffered all of it with patience and without any outcry, save that she now and then said: "Alas, what a poor unfortunate woman I am!" But had I, under normal circumstances, greeted her with a box on the ears that she deserved ten times as much, she would surely have raised such a hue and cry that you would still be able to hear her growling this very moment.

After this jest, I hastily dressed again and went back to where I had come from, namely to my cousin, the apothecary, to whom I was well-nigh unable to relate what I had done, so hard was I laughing. The housekeeper afterwards told me how covered with shit and battered and bruised she had found my wife after my departure; also in what fashion she had washed off the filth with cold water and used a medicament so that one should not see the bruises from the blows to the face she had received. I arranged with the apothecary that he should have me and my wife fetched the next day in a coach (and driven) to the meal; for I feared that she might be ashamed to show herself in public so well scarred; with that I took my leave and, as I had desired, left the house without any to-do before daybreak so that I might take my handkerchief with me together with its invisibility without anyone observing me. 



\section{Chapter Eight}

An artful fence to prevent strange bulls from getting in
your stall or cuckoos from laying their eggs in your nest

Thereupon I betook myself, when the gates of the city were opened, out to my garden, more to put my handkerchief in the little garden house for safe-keeping and to thus take off my invisibility than to do anything else in it. But at about nine o'clock I went home again and found my wife still resting in bed from the hard night she had gone through. I expressed wonderment, crossing myself, when I saw her so nicely banged up, and asked her what I knew better than she herself did, namely by what she had been so wretchedly disfigured in the, after all, short time of my absence. "O, dearest heart," answered the lying crow bait, "yesterday I wished to hang some white linen up on our upper story, and when I put up this ladder to this end, it slid out at the bottom so that I fell in a heap along with it and finally even down the stairs, which nearly cost me my life." I began scolding mightily, and said: "Wherefore do I keep a pool of maidservants in the house if you are going to do everything yourself. How do they earn their wages and keep? I've a good mind to take a cudgel and teach them to help their mistress better the next time." In particular I pretended to be very upset with the housekeeper, whose duty it rightly was more than the others to take better care of her cousin so that such misfortunes might be avoided, threatening to chase her the hell away if she did not show more concern for her in the future; my wife, however, excused her in every way possible and swore instead that she had not in the least been at fault in her misfortune, even though I knew better than she that this hide-tanning had been prepared and carried out on her with her cooperation. Finally, I left off 
my assumed rage so that I might have time to look to my wife all the more consolingly. I compelled her to get out of bed under the pretext that I feared that coagulated blood may have collected somewhere or other which might in the future cause her great distress or even put her in danger of losing her life, which coagulated blood, before it dried completely must needs be broken up and mixed with good blood by the patient's walking back and forth; in truth, however, I was afraid she might stay in bed and not come to the apothecary's meal, and thereby then hinder and destroy my plan, together with the profit and pleasure I hoped to obtain from it.

For just that reason I helped her get dressed and get up; I treated her as gently as a new-born babe; all I said came out full of sympathy and sweeter than sugar, and the terms of address I used with her were all of this sort: "O my heart! My life! My treasure! My soul! My consolation!" etc. Thereby I got her back on such an even keel that she was no longer thinking about, or at the very least was paying little attention to how her face looked, and for that reason she was all the more willing to sit in the coach when the apothecary arrived to invite us to be his guest and, at the same time, to take us along, especially when he said it was as necessary as it was advantageous for the purpose of breaking up the coagulated blood that she be driven a little in a carriage on the paved streets of the town and thus to some extent be shocked and shaken up. She adorned herself carelessly, in keeping with the constitution of her then distraught mind; I, however, put on my Sunday best in order to show the doctor what a distinguished fellow he'd have to deal with if he perchance in the future permitted my wife to goad him to put horns on my head. And so we drove to the apothecary shop and got out in the courtyard outside the garden where, in the merry summerhouse, the meal was to be held. 
Now while the young doctor (about whose presence, and that he would be dining with us, my wife did not know the slightest thing) was inspecting the apothecary shop, which inspections had been arranged only pro forma, I strolled about in the garden with my heart's darling and showed her the rarities and the wondrous plants which were growing there. I honored her indeed as if she were a goddess and caressed her as if I only now had begun to wish to spoon with her, and thereby got her into such a good mood that it seemed as if she had indeed forgotten the past night or as if during it nothing untoward had befallen her.

Now when the table had been set, the wine placed in cold water, and not only the tablecloth but also the floor of the garden house strewn, to increase our pleasure, with all manner of flowers both beautiful and fragrant, and sprayed and moistened all over with rose water, and they also already began to bring in the food, look you, there came the doctor walking in with the apothecary too, at which my wife, in both her visage and her gestures, so changed and paled that I could easily deduce from it how violently her raging anger roared within her. I, however, immediately ran to meet His Excellency and made a pack of French compliments, namely in what measure I rejoiced at the unexpected good fortune which so unexpectedly afforded me the honor of making his acquaintance, and I compelled my wife, both by urging her in a friendly way and otherwise imploring her urgently, to go over (in fact, however, she went like a snake or adder charmed to do so) to welcome His Excellency by giving him her hand, although I believe that she would have rather spat in his face. The apothecary, however, made haste to urge us to be seated, and thus brought my wife to the table where the doctor was before she was able to realize that she would be sitting as if on pins and needles. 
For straightway thereafter she began to make terrible faces, she looked like one of hell's furies, and her eyes blazed as if she wished to spit fire from them; she wiggled her arse back and forth as if she had wasps in it, she twirled her plate around back and forth the way Harlequin does his hat; and also the knives, forks, and spoons never seemed to be where she was satisfied with them; the corners of her mouth turned down like a bloodhound's; and not a word came out of it, and neither food nor drink went in. At first she appeared to be a deaf mute, and at the end like a carved statue. All of us-I, the apothecary, and the doctor-spoke to her and admonished her to eat, drink, and be merry, but to no avail, and therefore I took the occasion to make excuses for her to the doctor, saying: "Most highly esteemed doctor, be forbearing with her! Yesterday, in my absence, she tried to climb on to a beam and hang some white linen up in the upper story of our house, and when the ladder slipped out from under her, she fell down the stairs, which you can still well see from her face, so that today there will be little joy in her; and what worries me most is that I fear she might perchance have crushed something in her body which it will take her some time to get over. If, therefore you, doctor, were perchance to know of a sure remedy by which might be prevented the future danger which may arise from this, I request most humbly that you communicate it to me for your regular fee. Thereupon the doctor mentioned various medicaments, such as were useful to dissolve clotted blood, and told her in detail how she should use the one and the other; she, however, for her part did not deign to even look at him, but rather was thinking what the goldsmith's boy thought [i.e. kiss my arse], for which reason the doctor without doubt must needs have held her in his thoughts to be a crude and impolite woman, or even a fool.

Now after we had sat there this way for nigh onto an hour, the apothecary bade his servants, also the doctor's famula and my 
housekeeper, who was attending to her mistress, to go to eat too. I, however, did not wish to permit the housekeeper to go away at this time, but rather commanded her to stay with her mistress. They were scarcely gone, however, when the apothecary's boy came running back and cried: "You are to come, master; there is a city councilor here who wishes to speak to you about something right away." Thereupon the apothecary left, but the boy straightway came back again and said: "Not my master, but this gentleman here (pointing to me) is asked to come outside." Therefore I stood up and growled that I was not to have even enough time to eat a piece of bread in peace with honorable folk. I did not go far away, however, but rather stood with the apothecary behind some latticework where I was able to see and hear everything that my wife would now finally do with her beloved doctor.

She, at that point, was completely consumed with and possessed by rage; she had naught in her mouth but bitter gall, naught in her eyes but poisonous looks, naught in her heart but furious ire, and naught in her cheeks but fire and flames, and her face looked just as if the spirits of hell had taken up lodging there. The doctor, who had heretofore not had the slightest acquaintanceship with her, attempted, after I was gone, to speak with her in a friendly way, but barely had he opened his mouth when she interrupted him and said: "O you most ungrateful beast! You nasty, filthy pig! How dare you have the nerve to say even one word to me! You vile scoundrel and devil's cloaca, can it be possible that you are such a shit-gut that you are not ashamed of the scurvy trick you played on me? How can it ever be that a nasty shithouse like you does not hesitate to bring your stinking slutty carcass and repository of all filth into my presence? You miserable pig! I swear to you that if I did not wish to spare this place, and did not have other things to worry about, I should twist this knife in your body; but keep in mind that you never let me lay 
eyes on you again all the days of my life, and see to it that you get your stinking hoopoe nest out of here immediately!" Here my wife did not spare my housekeeper's ears at all, because she knew about her alleged secret; and the doctor was so taken aback by this that he sat there like a bump on a log and did not move a muscle. But so that he should not have time, either, to recover, I came back in with the apothecary and looked at my wife, who was still trembling with rage. I pretended that I was horrified with wonderment at the sight of her and said: "O, my treasure, how you do look! Sweetheart, what has befallen you? $\mathrm{O}$, my darling sweetheart, if perchance sitting in one place for a long time hasn't set well with you, then get up a little and walk a bit in the garden." She answered: "I must confess, I don't exactly feel like a parson on Easter Sunday." And since she therefore thought that I believed that she was ailing, look you, she forthwith became very sick, with the request that the apothecary should have her together with her maid driven home without delay, which was just the thing which I at that moment wished, sought, and found.

Scarcely had she gone when the doctor complained to me about how uncivilly and irresponsibly she had attacked and cursed him in the vilest language in the world. Now I was there again obliged to adapt myself nicely to the prank. "Alas!" I said, "now I know why she sat there so quietly the entire meal. She is unfortunately again in the state with which she has been burdened the last few years. Alas, wretched man that I am, what happiness have I to hope from her despite all her goods and gold? Most esteemed doctor, I pray you be so kind as to not only take that into account where she is concerned, but also to have Christian pity upon me, poor man that I am. There befalls her on occasions a melancholy condition in which at times she begins to rage to such an extent that in these fits of fury no one is safe in her presence; she utters the most terrible curses and insults to the most innocent folk and makes no distinctions at all between 
all those whom she then espies, and myself she mostly spares least of all. And what is worst of all is that she at times does not even hesitate to address the closest person to her and to belabor him with fists and fingernails before he knows what is happening and can protect himself. And if she attacks no one of the sort, then she vents her fury upon herself, as I now must really believe that she did not fall down the stairs, as she and my servants persuaded me, but rather that she did harm to herself, as you probably saw without difficulty from the look of her face.

The best thing is really that she soon comes to her senses again, else I should have had her put away long since; then she cannot find enough words to beg forgiveness of those whom she finds out she has offended. I also know that soon she will fall to her knees to achieve it of you, doctor; but if one were to exchange many words with her now, he would only make bad matters worse, and the more one talked, the more angry in her rage she would become."

The doctor hereupon showed himself quite sympathetic to my wife's great affliction and said, he not only would not hold against her how she had vilified him, but would also pray to God in the bargain that He might take from me and her such heavy heartfelt sorrow. And after I had hereupon pretended to be quite sorrowful, we took leave of one each other all the sooner. I, however, was joyous at heart that this plot which I had in mind had so excellently succeeded, for which reason there was enough to laugh about for me and the apothecary, who observed better than I with what sullen looks my wife graced her ring on the doctor's hand. 



\section{Chapter Nine}

One whoreson deceives the other, and the innocent party gets the short end of the stick

No one can believe what particular cleverness and excellence I ascribed to myself when I saw that I had played this farce so well and had made my wife despise the doctor and the doctor my wife, and had made both of them wary of and incompetent for a future war of Venus with one another, and insured myself to such an extent from wearing horns in cuckoldry. But fool that I was, I did not see what I should more rightly have seen and more assiduously observed, namely that in so doing I myself had become an adulterer, a deceiver and calumniator, in summa a fellow of the sort who, without God's grace, without penance and penitence, and without benefit of the unfathomable mercifulness of God, would never partake of His kingdom. Rather I rejoiced that my lost money had been exchanged for the invisibility by which I had so nicely thwarted my wife's plans and escaped cuckoldry; and at that time even if someone had offered to give me a whole ton of gold for my handkerchief, in which this power lay, he would nevertheless not have got it from me, so taken with it was I, even if both my temporal and eternal well-being were to be shattered because of it.

In this state of enchantment and defeat of my sound reason and my seventeen senses, I was interested in nothing more than that I, whenever I carried my handkerchief with me, must needs always be invisible, and that I was not able to be seen when I wished, unless I put it from me. I pondered back and forth on the matter and thought to myself: perhaps it too has a property like Gyges' ring, with which he, Gyges, according to how he turned it, was able to make himself 
invisible or let himself be seen when he so wished. Now what I imagined about it was indeed the case, although for a long time I was not able to determine it, even though I undertook all manner of tests with it, till at last I got to the bottom of it by accident. Meanwhile I always kept my handkerchief in my little garden house for safekeeping, because I had not the heart to carry it, invisibly, with me into my house; for I feared that if I were to carry it home and no one were to see me going about in the house, but afterwards I nevertheless let myself be seen, then my wife and servants would bode me no good. Therefore when I wished to be invisible I was obliged first to go into my garden, and when I wished to let myself be seen again, put off my invisibility there once more, which seemed to me to be a great inconvenience, of which I should have liked to be rid.

Interim my mistress housekeeper confided to me, even though not more than twelve days had yet past since I had eaten as a guest with my wife at the apothecary's, that she had determined that in three-quarters of a year the sort of sweets we had enjoyed that day would be revealed with hands and feet and begged me with tears in her eyes to stand by her with legal advice so that neither she nor I should come to shame. I answered her that we had acted with Freddie in mind; if she wished to have him as the father, then the matter would soon be arranged, and in fact I knew of no other advice for either her or me. And so I quite easily talked her into acquiescing to my proposal and letting the afore-mentioned Freddie, following his ardent lusts, run into the snare, and the sooner we set the trap for this purpose, the better; but she was highly troubled by the fear that he might perchance notice that the barriers had already been lifted for him, but she let herself be consoled by the skillfulness of the apothecary, who, at my request, so equipped her for combat that when she was to go into the fray and do battle with Freddie, the good ninny was not able to detect a trace of any warrior who had already 
fought the good fight, even if he should have had the sense of smell of an eagle.

Freddie was going about at that time and showing all the signs of a man in love, so that the housekeeper was quite easily able, with only a nod, to steer him and take him where she wished. To put it briefly, she appointed a night in which she promised to pair herself with him, and she did not keep it secret from me either, so that the two of them should have honorable folk present at the marriage too.

Now when that night came, I drank till I was half drunk, so that Freddie would proceed all the more boldly when he thought that I was now lying up to my ears in wine; but that did not cause me to sleep through the night time, but rather when midnight was at hand, I behaved in bed as if I were quite ill, almost as much so as the doctor, or rather I in his name, had done, and in so doing awakened my wife from her sleep, to whom I complained that the call of nature was compelling me to go to the jakes. Now, because a muttering then arose amongst the servants, perchance because for a short time now they had been remarking a ghost in the house (I know not whether they had heard me when I was tramping about invisibly, or Freddie when he was sneaking along after his lady-love), I bade my wife go with me so that I might not be afraid; she was quite willing to do so, for she perchance feared that otherwise I might go in the bed; she lit her wax taper with the night-light, and we both put about us our sheepskins, which people are wont to put on when they are either sick or at least do not intend to remain out of bed for long; and so we wandered with one another toward the privy through a long hall in which we were obliged to go past Freddie's bed chamber. There we found the door standing wide open and his bed still made up and not turned down. "Odds fuckament!" said I. "Now look you, wife, what manner of ghost is going about in our house! That's a fine way to behave! I estimate that if we look at the matter closely we shall find 
that either we have suffered losses from the pantry through theft, or one of our maids will wax like the moon. I'll know for once and for all where Freddie is this night." Thereupon I took my master key and opened with it the other two clerks' bedchambers; them I found in the places where they belonged; afterwards I had my wife go in the two maids' chambers, where she likewise found everything in order. Therefore all that was left was the chamber of her cousin, the housekeeper, a room the state of which I forthwith wished to see, at which my wife was heartily affrighted, without doubt because she knew of Freddie's love for her housekeeper-cousin, since to her herself she had complained about his importunity, but because of her own affairs and the amatory confusion which beset her at that time had received naught else save aid and consolation from her, which was such as to incite her, the housekeeper, herself rather than to thwart Freddie in his pursuit of her. Therefore she hesitated to open up the chamber and sought to find a way out by saying: "I shall never ever believe that my cousin would be so frivolous and would be remiss in anything which would be disadvantageous to her honor and to our sustenance." I, however, answered: “Cousin or no cousin! 'Tis always the one you trust the most who rides off with your horse. If she is our cousin, then we are all the more strictly bound to keep watch over her honor in our house." During this quarreling, which on each side stemmed from a heart convinced of its bad conscience, and by which each sought to deceive the other and to preserve, at the same time, his own and the housekeeper's honor, we drew near the chamber and found, after opening the door, the two lovers lying with one another in bed, and indeed, as can be easily imagined, not in such posture as if they had wished to pose for the double-eagle, but rather clasped in each other's arms and asleep. "Aha, wife!" said I. "Do you see now whom I trust?" She was affrighted, to be sure, but dared not grumble in the least at her because it was known to her that she herself was 
guilty of a greater misdeed; rather, she bade me to do what I of my own accord was more inclined to do than was she, namely to pardon my housekeeper, and for just that reason she got her wish all the more easily, too.

On the other hand, however, my good substitute, poor Freddie, was obliged to suffer all the harsher berating, and it could easily have gone so far that my wife would have dragged him out of bed by the hair; I, however, did not wish to allow it, but rather was content to listen to what a long litany of fine titles she read him. But since the housekeeper was weeping prettily, he trotted out the most heart-rending words to beg my wife's and my pardon. "'Tis unnecessary to relate all the formalia, much less what manner of sermon we preached him; 'tis enough to know the end of the song, the gist of which was that early the next morning he should go to the parson, have the sponsalia arranged, and straightway thereafter lead our little cousin to the altar in public ceremony, at which my wife as well as Freddie and the housekeeper were satisfied, but I best of all, despite the fact that I pretended the contrary and swore to high heaven, if I were not sparing the housekeeper because she was so closely related to my wife, then I should not leave her with her honor intact, but should rather chase both of them out of the house with scorn and shame.

Hereupon I went back to bed together with my wife, who thanked me most profusely for having behaved so decently on her account to her cousin and having settled the matter so nicely that she might still appear in the eyes of the world a person of honor; she extolled my excellent mind and said to my undying praise:

He is smart and worldly wise

Who does well at all he tries. 
But should she have known herself to be guiltless and known the true nature of this transaction in all its details, what manner of laudes would she have probably read me then! 


\title{
Chapter Ten
}

\author{
Journey to St. Michael's Fair in Leipzig, and thence \\ to Amsterdam
}

It happened, quite nicely, that just at that time there fell a church holiday which was so useful to the future married couple that they were able to wed a week earlier than would otherwise have been the case, because in eight days the bans could be read three times; for although folks are wont to overlook and forgive four weeks in newly wed women, 'tis still best in these cases where danger is to be feared that one chooses to go the safest way. Now after my wife and I had in this fine manner helped them to the cross they needs must bear, we gave her even more of a hand so that Freddie was able to set up a small shop in which to seek his fortune chaffering. I, however, at that time took my greatest pleasure in my invisibility, which pleasure then consisted for the most part only in sneaking up on birds and taking them down from the branches in my hands, which by itself so delighted me that I should not have given up again my handkerchief and what was in it for all the world's goods.

Then the time drew nigh at which I was obliged to journey on business to the Leipzig Michaelmas Fair; I should have liked to take my little handkerchief along, but knew not in what manner, for when I had it with me, I was invisible; but how would I be able to do business with someone if they could not see me? I saved it over in the form of a large package so that indeed naught of the material contained in it, and thus also perchance the real piece, which had the power, might not be lost. I need not worry that this package would be easily stolen from me, for when I put it from me, one was not able to see it but easily to grasp and feel it. I had a saddlebag in which I 
was wont, according to the occasion and time, to carry money overland when I traveled anywhere on business. This I took with me to my garden to pack in it along with other things, such as anemone roots and flower-bulbs, also my little handkerchief, since I had persuaded my wife that I had promised to make a present of these garden rarities to one of my good friends and patrons in Leipzig. Now as soon as I had put my little handkerchief in, look you, I was no longer able to see it, but was well able to feel or grasp it; whenever I then took it out again, then I saw it again. This I tried out several times, and after I had thus assured myself of the thing's nature and effect, I should also have liked to know whether people also did not see me when I carried the invisible saddlebag with me. I tried it out at first on the birds and found that they did not wait for me as they did when I had only the little handkerchief with me. Afterwards I stood at my garden door by the road and learned from the greetings and honors which passers-by gave me that I was seen and therefore the power of invisibility extended no further than to the saddlebag. In this manner I, in visible form, took my invisibility in my invisible saddlebag home, where I pondered the matter further and found that my little handkerchief, kept in a little leather pouch, made the little pouch, of course, invisible, but not him who had it with him. And thus, I was now able to carry my invisibility with me and let myself be seen, without putting it away, or make myself invisible with it when I wished, especially since I made for myself for this purpose a special leather bag and carried in it the package which I had formed out of my little handkerchief.

Just at the time when I was busy in my little garden house with my investigation of the just-mentioned property of my little handkerchief, I heard in the garden situated next to mine, which belonged to a distinguished and wealthy gentleman of the quill, a woman lamenting her misfortune with weeping and sighs; she was somewhat 
too far from me and spoke her words of lamentation so secretly that I was not able to understand them, and the place where she was lamenting lay just behind a currant hedge, so that I wasn't able to see her either. But because I should nevertheless have liked to know both who she was and what was ailing her, I took to myself my little handkerchief and sneaked to her in the garden. Look you; it was the cousin and boarder of that woman to whose husband this garden belonged. I was unable to divine what else could be troubling her save that perchance she might be in love; for neither of wealth, nor youth, nor beauty, nor other things which Fortune might give to a young lady in this world, did she lack the least thing. She used up annually for her upkeep (although she lived splendidly) not half the income from her estates and revenues, which had been left to her seven or eight years before by her deceased parents. To all outward appearances she lived so pleasant a life that anyone would have been hard put to guess what better one she could have wished for, and had, moreover, not only a half dozen honorable and well-born suitors, each of whom hoped to earn her love, especially since both widowers and bachelors are found around such a wealthy and beautiful woman just as frequently as wasps and midges are around a fat honey-hive. In addition, she had her choice from among many, even though the least among them all was such that she durst with quite good conscience take him as her spouse.

I had scarcely taken up a position at a place where I intended to eavesdrop further on this lady when I saw squatting in another corner her cousin, who was likewise listening secretly to her. She had her hands clasped together, just as if she herself were uttering the laments, and was staring so at her cousin through the rosebush there that one could easily conclude from it that she had already understood with horror the lady's problem and was participating in it with rare sympathy. Meanwhile the other woman was still continuing to 
weep, so that on her rosy cheeks one tear was scarcely able to escape the other, without her letting pass several explicit words from which could be remarked what was perturbing her, since she was lamenting a wanton Panphilius, to whose godless sense of honor she had entrusted more faith and belief than she should have and than he merited. Aha, thought I to myself, assuredly your maidenhead has suffered a shipwreck. What I thought to myself was indeed the case, and not only this but even more still, namely the reward which a woman after such work is occasionally wont to carry away in her belly. And I was straightway assured of this, for when the cousin imagined that her little cousin would babble naught further and more specifically than what she had already heard sufficiently clearly from her words (since now she was making shift only with weeping and thereby affirming what she had said before), she moved out of her ambush and surprised the so plaintively weeping mademoiselle in the second rank of her seizure, when she was able to repulse neither the attack of her sighs nor the flood of her excessive tears. "What is this, young maid, or better, young woman," said she, "in what state do I find you, in which I never foresaw that I should encounter you? Now I am assured that I actually know the reason, which I have hitherto only suspected, why you have recently several times felt ill. Just confess the affair to me quickly and tell me who the father is so that we may take counsel betimes and preserve you from future shame. Do not conceal from me, your best friend in the world, even the slightest thing, for just as one should put the best face on what cannot be undone, I shall also do in this matter what it behooves your closest relative to do, as one who must needs share both your honor and your shame."

Hereupon the good, all too merciful or too gullible maiden howled for a good while afterwards before she was able to recover herself to speak; but finally she said: "Most esteemed cousin, you never, to be 
sure, bade me do what I did, but on the other hand you did not warn me either about what would happen to me, but rather gave me free rein and permitted straw and fire to come together by allowing me all too great a freedom and intercourse with your boarders, whereby I, a poor and inexperienced thing, easily strayed with the flames of my ruin. 'Twas Monsieur N., a cavalier as valiant and reputable as he is wanton and forgetful of honor, who deceived me by feigning unbearable love for me and promising to be ever true to me, and who after promising with terrible oaths to marry me, robbed me of my maidenhead and led me, as it were, into that which I received from him. When he recently departed from here so abruptly, he swore to me by all that is holy that he was doing it to speed up our union in holy wedlock; but today I receive a letter from him in which he notifies me that his most noble friends, who are related to princes, will never allow him to wed me, even should I be ever so wealthy, and now he is moreover compelled to marry a lady from the family of a high-ranking count, which lady's powerful relatives he dare not offend, which without doubt would not transpire without danger to his life and loss of his considerable income if he were to prefer a person of lower birth to their relative."

When she had thus confessed all this, she began to weep again as if she were about to despair; her cousin was therefore obliged to console her all the better. "Odd's blood, cousin!” said she. “That's no reason to hang yourself. You are not the first and without doubt will not be the last who has been betrayed by faithless men. You must fight this evil sex with their own weapons and pay them in their own coin. Just be of good heart, dear little cousin, and let it be of particular comfort to you that I treated my husband the same way too; for I too became pregnant while single, and in fact not by one of my own class or by a nobleman who did not wish to marry me, but rather by my cousin's manservant who dared not sit down where I put my 
feet; and indeed not by a man who seduced me but by one whom I myself teased into doing it. Now when my mother, God rest her soul, caught wind of it and saw through it she sent me to one of her country estates, where I secretly gave birth and had the woman in charge of the farm put the child as a foundling in a place where he is still being brought up and now is about nine years old. You can well imagine that before my wedding (although I knew that everything that had happened had been concealed from everyone) I had trepidations about the wedding night, out of fear that my bridegroom might perchance notice something; but my dear blessed mother was much too cautious for that; she made my breasts as rigid again as if no man had ever touched them, not to mention that a child had sucked at them, and otherwise so arranged things with me that my husband must needs have had a keener nose than he did if he were to scent anything but an immaculate virgin. I still know the recipe, and it will stand you in good stead. Now should anyone know the truth, save our above-mentioned overseeress, who was present at the birth, and were they to say anything about it to my husband or reproach me about it, then I know that he himself would swear on my behalf, pursue such a tattle-tale as the worst calumniator, and compel him to confess his lies for the truth by recanting.

"I must often laugh myself when I think of how nicely the deceit went for me, and how sympathetic my husband acted when I behaved so badly on the wedding night in bed with him. And, dear little cousin, you must simply do the same thing, for I see no other remedy for it. I shall send you to the widowed sister of my mother, with whom you may stay secretly till you are relieved of your body's burden and have got a good color back. She will assuredly help take care of the child; then you can come back here to my home and make an honorable marriage with one or the other of your suitors, over whose eyes we shall then pull the wool just as I did with my husband." 
The young lady listened to this discourse with such attentiveness that her weeping was in fact dispelled by it; she thanked her cousin for the good advice she had given, and promised to follow it faithfully. I, however, considered the manifold deceptions of cunning womenfolk, which I had perceived, through the power of my invisibility, in my own wife and her housekeeper as well as in this so reputable lady. But I did not think at all to punish myself too, and to consider that if there were no wanton young fellows, then there would be no whores either, but rather I resolved to henceforth dispense with the company of all women and, so that I might be away from mine, not only to travel at the earliest opportunity to Leipzig to the Michaelmas Fair, but also to travel from there for a time as far as to Amsterdam, where I was well known anyway, since I had been brought up there from my ninth to my seventeenth year, and had there laid the foundation for learning the first things about business and commerce.

In this small world, in which one can see nearly the entire great world, down to the last detail, I arrived six weeks after my departure, after I had first instructed the apothecary how he was to behave till my return toward my wife, my business and my whole household, especially since I had taken along with me as much money as I thought I needed in the meanwhile. 



\section{Chapter Eleven}

How is one to plan ahead now? Will war break out, or shall we remain at peace?

When I arrived in Amsterdam the word, or the question, "What is the news?" was so common with everyone that it appeared as if the high and lordly states of the United Netherlands had chosen it as their motto. I feared at first when I heard it put to me only by my old acquaintances so continually, they might perchance have report that I was able to make myself invisible in such a rare and yet entirely new fashion, for scarcely one of them had bidden me welcome when he straightway came at me with this question, without even having asked how I was living, how my health was, what business I had to accomplish there, and the like. But after, in time (which brings experience) I looked at it in the clear light of day, I became aware that it was because they feared that the Most Christian King might begin to bother them if he wished to become, as they regarded it, a wealthy merchant there, or at least to relieve them of the lands and folk that they as common tradesmen possessed, and take possession of them himself as a king who was born to rule. Now when I remarked where the shoe was pinching these Netherlanders, I, as a German who was unaffected by the matter, was somewhat satisfied, but did ponder on the consequences and on what might finally result from them for my native land.

While I was turning these thoughts over in my mind, I asked myself whether there would probably be a war or not. But to answer this question of mine I deemed myself much too trifling and less than nothing; for this is up to the prophets, and to be sure not all of them, but only those to whom God reveals it (in order to warn mankind). 
I know not whether anxiety or curiosity goaded me on to know anyway that the Almighty reserves unto Himself alone the right to know such things. I should have liked to ask a Jerimiah, but there was no living soul or one of his ilk there to satisfy my curiosity; and I knew of no pagan sybil, either, who might have given me an oral report about it. Therefore I went to those who have been called since time immemorial Chaldeans and bought me at least seven dozen calendars of their divers disciples or followers who had put them in print. But I found just as many mutually contradicting predictions, as there were prognosticators, just as many cumbersome outré statements as there were authors, I'll well nigh say just as many lies as there were soothsayings. Even though my curiosity was still tormenting me, and I believe that if the itinerant scholar had been there then who helped me to invisibility, I should have gladly presented him with a dozen new gold sovereigns if he had only filled my brain with even more such empty crotchets of mendacious predictions, even though 'twas well known to me that Apollo himself often said to those who asked him questions:

Why trouble yourself and me in vain?

The future's look is never plain.

All this nevertheless did not get me out of the hospital for curious phantasts, not to mention cure and liberate me from my sickness; but rather I searched day and night for a satisfying answer, as the alchemists do for their lapis, just as if I myself must needs put land and folk, crown and scepter, in danger of loss by doing so, and became so silly about it that someone who merely saw me running so earnestly after the news and heard me asking so zealously about it, might very likely with clear conscience and without committing any deadly sins, have written my name down in the roll of great fools. 
I had taken lodging with a matron who was used to renting them out. It was a chamber together with a bedstead of which I need not be ashamed when reputable folk came to visit me, and then I had no lack of either men or women to wait upon me, for this old woman had well nigh more maidservants than lodgings to rent out, and therefore also a great traffic in all manner of men of quality of whom one would not have expected that they had need to let themselves be served in this fashion. Thus I soon made, not counting my old acquaintances, the acquaintance of many other diverse people who visited me on occasion and I them in return. This, however, commonly was done at slight expense, for we did not eat, drink, and gamble as much as people were wont to in my homeland, but rather most times came together just for a pipe of tobacco and a drink of beer.

And one time such a society was together: five Hollanders, a man from Hamburg, and I was the seventh, and even though, as stated above, we did not drink heavily, we did imbibe so much that we became tipsy from it, in which condition people are commonly more candid than when they are blind drunk, and more confiding than when they are completely sober. Now when we were talking about all sorts of things concerning business, for we were all merchants, one of them said: "We are indeed making our calculations about our business transactions, but know not whether peace will continue or not, and in times of war these transactions move as erratically as a crab rather than going straight through as is desirable." Thereupon another Hollander answered: "Who is going to declare war on us? We are members, with Hispania and England, of a sancte concluded Triple Alliance; in Denmark we have a loyal land, as it were an allied neighbor to stand by us in all contrary events; the king in Sweden is still too young to really touch us in person, and the ministri of his crown will think twice before beginning with us so difficult a 
labor as a war is, which they afterwards, should it not have turned out as they wish, must needs answer for when their king comes of age; France is not man enough to achieve mastery over us, for 'tis indeed sufficiently well known what long resistance and excellence progresses our forefathers offered to the mighty crown of Hispania, and that indeed, which is more important to bear in mind, when it stood at the height of its power, whereas our folk were held to be beggars. Moreover, we have an incomparable navy which no intelligent ruler will ever scorn, and are so well provided with money that we may continue the war both on land and sea for a long time, so that it is not at all probable that we need anticipate a war."

This was the one Hollander's final conclusion, but the other one thereupon said: "All this which you have brought up can nevertheless not assure us a lasting peace. The Triple Alliance, to be sure, appears to be sufficient for this, but remember, too, that we have to do on the one hand with a mighty monarch who is of a different faith than ours and was in times gone by our forefather's natural lord, and on the other hand with the English, the most variable and fickle nation in the world, both of which are competing with our welfare and happy prosperity. Should that mighty crown really feel no pains and antipathy but instead still remain loyal and kindly disposed to us when it remembers that we strode from under their authority and on land and sea, and not only in Europe but also in Africa, in the East and West Indies, yea even in the furthest corners of the world, did them insurmountable damage which they will never recoup? The English, however, even though our neighbors and a faith akin to ours, are they going to be able to tolerate in the long run without inward griping our sailing and enjoying the sea like them, and through our maritime power prospering on it more than they themselves, the sea of which, after all, they heretofore imagined themselves to be the sole and highest master? Brothers, born of the same parents and of 
the same blood, are wont to fall out with one another about earthly realms and kingdoms and finally to pursue one another so mortally that often neither of them can be satisfied save with the other's total demise and death. Now, should this not also occur much more easily between neighbors because of ruling the seas? Keeping possession of what is allegedly mine and thine is the cause of all wars, and accordingly our Triple Alliance is not as firm and secure as one may well think."

"And also," said the third one, "Denmark is not to be so firmly relied upon. Kings do not like to be allied to their inferiors, even though we had been of even greater military service to the Danish crown and had a state twice as powerful as it is. As far as Sweden is concerned, kings are not children even though they are still lying in the cradle; rather, on the contrary, that same nation is a warlike one and has been up till now a fortunate folk in war, even when it was ruled only by women, and a folk who without doubt still harbor a secret grudge stuck in their craw because of the aid we gave the Danes."

The fourth Hollander said that France was not to be regarded with contempt, for if it ever took up arms it would not make war against the United Netherlands as slowly and dispassionately as Spain had done earlier. France had its forces collected in one place, and it would not be as easy to cut off its sinews of war, as had befallen the Spanish in earlier times in the Indies. The French king, he continued, was one of the most valiant, one whose high ambition would spare neither reason, nor money, nor people, in which three things he was by no means lacking, to achieve dominion over the entire world. But that one should think, just because the United Netherlands had liberated itself from obedience to the Spanish crown at just the time when it was most powerful and when our forefathers, on the other hand, had been held to be mere beggars, they might now easily withstand the crown of France too, would find that he was deceived in this; for the 
fact that at that time the United Netherlands had obtained its freedom and had preserved it till now was by no means to be ascribed to their weak strength and their own bravery at that time, but rather to the assistance of the crowns of both England and France, without whose aid the states of Holland would never ever have been able to progress so far. 'Twas indeed a fact that at that same time it appeared that the crown of Spain intended to make itself ruler of the entire world, so that one might with good reason wonder how the Hollanders might not only escape such a mighty power but also weaken it in the bargain, indeed even vanquish so many of them; but when one considered that all the potentates to whom the great power of Spain was threatening had also for that very reason resisted the house of Austria and otherwise kept it everywhere sufficiently busy, then the wonderment would soon cease which one might have because of the fact that Holland and the other United Provinces had become free and great."

The fifth Hollander hereupon answered: "Let matters be as they might, these were all old matters which were of no import save that one might incidentally deduce from them how France would fare if she made so bold as to place the United Provinces under her crown; so many sizeable and in part unconquerable fortresses could not be gobbled up as quickly as cold applesauce, much less digested, or as easily kept as conquered. Moreover, the United Netherlands was so choice a morsel that the other Christian potentates would hardly grant and give it to the crown of France, much less let it fall to France, considering that if the French king should conjoin their sea power and moneys with his own mighty wealth, and, as could be foreseen without any doubt, were to avail himself, in the bargain, of the usual French policies, that then no king, indeed even the German Empire itself, would be hardly equal to him any more if he wished to likewise subjugate them one after the other." 
After this Hollander had presented his view, it was now the turn of the man from Hamburg to speak: "Our question was whether or not peace would continue. To that I shall answer in accord with my slight understanding, that Holland should really prepare for a war with France, for why else should the French king be arming himself so mightily? Hispania he has already sufficiently plucked of her feathers, and can no longer find any pretension to some pretext or the least vestige of fairness to support further abuse of this crown's patience and forbearance. With the Swiss he will hardly create friction at this time; to move against the German Empire will be inadvisable for him; Sweden is his friend; with Denmark he has nothing to do. Now who else is there save the state of the United Netherlands against whom he may sharpen his weapons, and with whose ambassadors he has already begun disputes anyway? I fear, I fear, and may God grant that my fears be in vain, you Hollanders will be obliged to receive a black eye, provided matters go on that well for you; for I see that you live securely, just as if the king of France would be terrified at the sound and fame of your government and would not dare even turn to you because you have hitherto remained unconquered. You yourself have doubts about the Triple Alliance, and how quickly it could be destroyed by him if he gave back to Hispania what he has hitherto taken from her and thereby persuaded her to share like a good blood relative the divided Netherlands with him. Moreover, I see (and I pray you forgive me, gentlemen, if I speak the truth here) your great arrogance, which shines from afar, as if you were not at all hesitant to prescribe laws to every powerful potentate; which pride annoys the princes and commonly goes before a fall. But do not doubt me that after the fire of war has flamed up with you, you will, with both money and cleverness, direct the course of its flames elsewhere." 
“That I too believe," I hereupon said, "for we still remember how many an enemy the Dutch in their foresight with their money sent into the German Empire to plague the house of Austria when Spain was earlier fighting a war with Holland, so that Austria might have enough to keep it occupied elsewhere and thus not compel with united forces the United Provinces to again be its obedient servant. In addition, I see our nation to indeed be ripe for divine punishment, which is not only downright invited, but even forcibly compelled as it were by all manners of sins and vices of both old and young, great and small, rich and poor. I shall not only say nothing of pride, envy, greed, etc., in our old and great cities, but will also keep silent about the luxuriousness and godless life of our undisciplined, unruly, wanton, and lecherous youth in our small villages. Just go into one of them where such young fellows are together either half or completely drunk, and you will see and hear in public such things as heaven might turn black at, from which it is easy to surmise for what manner of divine retribution our citizens are making their fatherland ripe and ready, to which retribution you may perchance give its beginning." 


\section{Chapter Twelve}

The best remedy for war is sought and found, but the worst is chosen

After each expressed the opinion that there would be a war between France and Holland, which might finally spread over all Europe, my company parted from me, and I pondered on the ways and means by which I might safely escape its dangerous currents. I had heard from a magician that at this time of our saeculum a war would begin in Germany and at last end in France, and that the Roman emperor would deal six hard blows to the Most Christian King; therefore I thought indeed, such a war would also affect the Roman Empire and thus my fatherland too; for which reason I was all the more worried and meditated how I might be able to bring together a considerable sum of money in diverse gold coins which can be packed up compactly and on which I might live, and to bring it together with myself and my family, to the safest possible place, which I also trusted I might also easily do by means of my invisibility; to this end I forthwith tried out my plan on a rich Portuguese Jew who, as it was generally believed, did not know himself the sum of his great wealth.

I made myself invisible and went into his house to sniff out therein where the best treasures lay, but nevertheless dared not be as loud there as if I had been at home there, so that my invisible presence might not be remarked and my plot thwarted. Even before I came to the house I heard someone singing the beginning of a little song which I held to be an infallible omen that war really must needs be at hand, and therefore I became all the more eager to fill my sacks betimes. The song began as follows: 
Old Simplex and Hopalong too,

Neither fellow has a sou,

And no innkeep will pour them a drink,

So both live on poverty's brink.

O brothers, be of good cheer-

A change in your future is near.

You can tell by the way folks act

That war must soon be a fact.

The content of the following stanzas told of the godless life of all manner of people of rank, and finally came to the conclusion that without War, Pestilence and Famine the world might not be made better again; and although the simple artless rhymes were forged in the manner of Hans Sachs, the content was nevertheless so reasonable that I could not but take it to heart as an infallible prophecy, although I am otherwise not at all wont to be so superstitious.

Now, as I was sneaking about here and there in the house, which I can quite well call a palace, I found it stuffed with everything which rich people are wont to have; only the cash money, because it, together with many precious jewels, was kept in a vault and was protected by several locksmith's locks; and therefore I was obliged to consider getting my hands on the keys, to which end I sniffed through all the rooms and in one of them found a woman embroidering a sword belt with gold, silver and pearls, at whose incomparable beauty I was indeed astonished; for she was so uncommonly and indescribably beautiful that I can never more be persuaded or believe that a painter is to be found in the whole wide world who could paint a more beautiful picture. Her dark brown eyes so gleamed with lovely glances that they would have been sufficient to ignite the whole world with the flames of love, if only they had been cast on the eyes of men as well as on the beautiful pearl-work of her alabaster hands. For just 
as she herself took joy and hearty pleasure in this excellent work, or rather work of art of hers, she cast upon it, as a thing which she dearly loved, with a smiling face, as it were, many tender glances, which were such that in a trice their power could not but go straight to the innermost heart through the eyes of those on whom they fall and place it in the bonds of love, even if they were of hard steel; indeed, even of cold crystal and diamond. When I saw straightway at first glance, just as she was immersed in this devotion towards her work and therefore was sitting stock still, how artfully and beautifully the pale white and the lovely rose color were mixed and distributed in her face, which was formed in a most exceedingly beautiful manner, and also saw that her lips shone forth as if painted with vermilion d'Espagne, I thought the entire picture might be some artful master's best work of art, such as those life-size statues carved of wax and splendidly clothed which they toured with in Germany and showed for money; but when she moved again and began to embroider, I was overcome with wonderment precisely as Pygmalion may perchance have been when a living soul was poured by Venus into the beautiful virginal statue which he himself had so industriously produced of ivory. I stood there completely enchanted, or, to say it closer to the truth, completely smitten, and was able neither to see my fill of this excessive beauty nor to wonder at it sufficiently. Nothing Jewish was I able to remark about her save a very little bit of her well-formed nose, which, however, in my eyes served her better as an excellent adornment than that it should have been deemed a signature of a Jewish physiognomy. The jewelry in her hair and around her neck, her earrings, her rings and bracelets were of great value; her slippers, like the sword belt which she was embroidering, and her dress were of such cloth as private persons of that sort are not wont to wear every day. Her sugar spheres she had pressed in carelessly, and therefore their rising and falling delighted me most of all when she 
breathed; and as I gratified in this fashion the curiosity of my eyes, I quite unknowingly quaffed in deepest draughts the sweet poison of love, and did not become aware of this till I wished to go away and was yet almost unable to take my eyes off the uncommon beauty.

I was already married and had in my days served many a ladylove, which doings are commonly driven by the motivation of love, by virtue of which I too, because I had thus gone a-wooing, had had enough to do with it and its passions; but that seemed to me to be naught but jest and child's play compared to what I now was suffering. For after I had once seen this Jewish maiden, I had no peace any more, neither day nor night; no sleep came to my eyes; all the merry gatherings which I really sought out on purpose, were odious to me; all I did was to feed myself on pains, to drag about with melancholy thoughts, and to work myself sick with all manner of laments, vain effort, vexation, many sorts of profound reflections and otherwise with a thousand kinds of fantastic follies and foolish plans to enjoy the favors of my beloved. Otherwise I allowed all honorable business and my entire trade to go their merry way, and although my wit and mind hereby became dull and useless, my flesh, together with the powers of my body, also dissipated, just as if I had come down with consumption. Thus I learned only late what manner of nature a really violent love has, whereas I, as a married man, really should have needed the useful precept of Vergil, when he says

Vina sitim sedent, natis Venus alma creandis

Serviat; hos fines transiluisse nocet.

That is

Venus for modesty, for thirst wine;

He who goes to excess profits little.

This state I was in, which grew daily worse, would have been more than sufficient to little by little enervate me and finally even 
bring about my death, but (so it seemed) I was not to get off so easily; the nature of my fate turned out to be much more cruel, and the insurmountable obstacles and vagaries which prevented me from fulfilling my desire were so powerful that they threatened to make me finally despair such that I began gradually to wish for my death, so that I was well able to lament with that Italian:

O notte, o cielo, o mare, o piaggie e monte,

Che si spresso m'udite chiamar morte!

In English:

O night, o mount, o sea, o hill and sky,

How oft you hear my wish to die!

Indeed, I did not leave matters thus, but rather seized the most extreme wish of angered and desperate lovers, namely that heaven and earth collapse, so that I might see an end to my misery, which wish Alphenus Perusinus expressed in Italian this way:

Piovan dal ciel con tempestosa furia

Folgari ardenti, che ciascun sommergano.

Contalicus translated it into Latin as follows:

Totum terribili quatiatur turbine cœsium,

Cunctaque dispereant corpora fulminibus.

And in English:

Heav'n and earth alike collapse into a heap

So that no man may escape a fall into the deep.

To be sure, that my beloved was a Jewess caused me the least vexation and distress; for to such a conscience as has had the impudence to get back his money with the devil's help, 'tis all the same whether his bestial lusts are accomplished with a baptized or unbaptized piece of flesh. On the other hand, what gave my heart the greatest sorrow was that I knew how exactly and carefully the Jews are wont 
to protect their women from a fall, and indeed especially those who are virgins. Secondly, it was not my slightest care that nothing could be accomplished in this instance with money and gifts, which otherwise generally prevail everywhere, make all mountains and valleys level, and carry the victory over every town, since it was common knowledge that her father had as much of it to throw away without particular diminution of his inestimable riches as I should be able to get together my whole life long. Thirdly, it was a sharp thorn in my side that the Jews, women as well as men, hate us Christians, by nature as it were, and esteem them to be not much better in their minds than dogs, in comparison to themselves, the issue of Abraham which still imagines itself to be God's chosen people and hopes sometime in the future to rule the world under their future Messiah. Fourthly, I got not a few gray hairs and hollow cheeks because I dared not gain access to this place through either pimps or panderesses, for which folk, with their famous cunning, crafty deceitfulness, and daily newly devised tricks, no virgin can be too chaste and proper, no widow too cautious, no married woman too shrewd, no resolve too firm, no intent too strong, and no continence too steadfast, and no stone so hard and fast that it cannot be moved by their continuing efforts, against which neither force nor guile, neither caution nor wisdom, neither celerity, art, nor adroitness can accomplish anything. Now the better these folks' dexterity was known to me, the more it pained me that I knew not how to make use of them on my behalf. Fifthly, I saw myself in a city wherein nothing could be accomplished by force, because the Jews live there under the most secure protection; and to attempt anything by intrigue seemed impossible to me because, as you have heard above, the Jews protect their womenfolk so well. To make myself known to her and to wait upon her as a serviteur, even if I were perchance able to secretly and unnoticed run my shuttle into her, seemed to me to be just as scornful as dangerous. 
I believe that evil Satan has much more power to tempt with the greatest possible vexations those folk who have become accustomed to rolling from one sin to the other, and more brazenly attacks them than those who have zealously been on their guard against vices; for look you, 'twas without doubt from this arch-fiend's prompting that I got the thought to say to myself: How would it be if you had yourself circumcised, especially since in Amsterdam this is nothing new? But hardly had I had this thought when I saw also what a horrible abomination it was. No, said I, this idea and suggestion comes from the devil. You should rather die a thousand times than deny Christ as your Savior! Had I at that time had my reason still fresh and sound, I should have also thought and concluded that the love which I harbored toward this maiden could have its origins from none other than from the devil, in order to thereby deprive me of my Christianity and thus of eternal bliss. But alas! I let matters remain there and was of the opinion that I had done enough and a noble Christian deed when I was unwilling to deny Christ publicly, whereas on the other hand I felt no bad conscience at all about adoring the Jewess' image in my heart all the time and presenting her with many thousands of sighs of love.

The only comfort of my disconsolate and miserable life was that I went almost daily, invisibly, to see my dearest and to feast my eyes on her wondrously beautiful face. But why do I call this folly a comfort when it was really naught else but oil poured on my flames, which flames of love grew higher, the longer I looked? Thus I loved without hope of satisfaction and tormented myself by reflecting about whether it might not be possible to help myself out of my misery one way or the other. But no expedient was to be found there, unless I wished to hang or drown myself, which even at that time did not seem at all acceptable to me. Meanwhile I found out the name of the Jew and all who lived in his house, and became as well acquainted with all the 
nooks and crannies in the house as if I had been born and raised in it. I also found the place where the Jew's cash, silver plate, and precious jewels were, which in truth was a treasure the likes of which were not to be found in the home of many a count in German and French lands. But I left it all untouched, because not rich Eliezar's gold, silver, and jewels, but his beautiful daughter Esther was for this time the treasure for which I yearned.

Once, on a Friday evening, I again found myself in Eliezar's domicile and watched as he, Eliezar, as the father of the family, after reciting many words of praise, which they call the haudila (which means "division, separation," namely of the Sabbath from the other non-holy days), in his damask sheepskin lined with marten, sprinkled a large gold-plated beaker full of wine throughout the entire house, saying as he did so: "May the prophet Elias, the prophet Elias, the prophet Elias soon come to us with Moschiah, God's and David's son; may the prophet Elias, etc.," which ceremonies gave me the reason and the opportunity to devise that plot which afterwards gave me the pleasure of my love. 


\section{Chapter Thirteen}

\section{What the Jews think about Elias and believe about their future hoped-for Messiah}

At that time there was staying in the city a fellow of the Hebrew race who had had himself baptized a year before and in this holy cleansing had himself named Erasmus. He was well educated, of fine appearance, and of honorable behavior; about twenty-four years old, and also rather poor and needy, so that he often was obliged to make do by playing the toady. He taught some merchant's children both to write and to speak Hebrew, by which he, taliter qualiter, made shift, and had from several chiefs of the East India Company promises to have, the next time some East Indian ships departed, a post with the fleet such that he might not only make a good income at it but also move upward and gain fame in the bargain. Now because he was well versed in both the Christian and the Jewish religions, and especially since he hated the Jews and was mortally hated by them in return, he revealed all their superstitious secrets to all with whom he became acquainted and who for amusement desired to hear them from him, and in fact I once encountered him in a merry company of young merchants to whom he was relating a whole heap of ridiculous things about them.

Now when I dared not undertake anything in my love affair either with money or force or in any other way, and had therefore decided to seek by intrigue or deceit my salvation, or rather damnation, with this superstitious and thus so silly folk, in which my invisibility would stand me in good stead, I deemed it necessary to make the acquaintance of this fellow, in order to learn thoroughly from him about the Jews' beliefs, customs, and transactions, so that I might be able to place and set nets and snares with which I thought 
to cheat Eliezar out of his daughter's chastity. I accordingly invited Erasmus in a friendly way to my lodging, and pretended that I had a great desire to learn from him to read and write Hebrew, and he was quite willing and indefatigable in serving each as best as he could.

In two days I knew the Hebrew alef-beth perfectly, and in other ways continued to learn so quickly that my teacher himself wondered at it. And when we ate together or strolled idly about, I gave him cause to say something about the Jews' beliefs, devotions, hopes, and usages, which things I inquired after so eagerly that Erasmus asked me in jest whether I wished to become a Jew, too. But I shall tell you, most honored reader, so that I do not abuse your patience, naught more of this than what I think may serve you in explication of my history.

About the person of Elias, Erasmus told me that the greater part of the Jews believed, but without foundation and solely from the inherited sagas of their forefathers, that Elias had been alive already in Abraham's time and had been his faithful servant and the oldest hired hand of this family, and according to Genesis 24 had fetched Rebecca, Bethmel's daughter, from Mesopotamia for Isaac to take to wife; also, that at the time when Sodom and Gomorrah still stood he had much teased and tormented them on account of their godlessness, and because the Sodomites along with other vices were so much against hospitality that they made a public law that all those who invited a stranger to a banquet and treated him like a friend, such as for example the robber Cacus did, should lose life and limb, and therefore they had guest bedsteads varyingly both long and short in which strangers who happened to come there to spend the night were obliged to lie, which guests, if they were not just as long as the bed, they either stretched till they reached this length or, if they were too long, they cut off at the head or the feet till they just fit the bed; and such law and evil customs they had introduced so that 
they alone might waste in debauchery the rich superabundance of their lands, which flowed with milk and honey, and so that nothing of it might redound to the advantage of any foreigner or neighbor; and also so that they might carry on all the more unhindered and wantonly, when they became heated by wine for this purpose, their various lewd Sodomitic practices unwitnessed by a stranger, before whom they still did feel some shame. So this Elias, Abraham's servant, in order to mock them and so show them how unwisely they legislated, and also to hinder them as much as possible in their sins, had appeared at a general feasting of the Sodomites and had shown himself equal to a native in eating and drinking, which so vexed the envious and jealous Sodomites that they decided to punish with death the man who had invited him, or at least been the cause of his admission to the company and his presence there, and to punish him, Elias himself, with the bedstead as was their custom, for which reason divers persons asked him who had brought him to this banquet; to each and every such person individually he had answered that he, the man who asked the question, had invited and brought him there together with others; at which reply each had drawn away from him fearfully, like a mute. That night they wished to kill him anyway, even if he fitted into all their beds, the long as well as the short, as if they had been made to measure for him; but they were struck by God with blindness, as later in Lot's time, so that Elias came back to Abraham's cottage without any harm having been done him. They have many more tales of that sort about this Elias and say that he was placed in the service of Abraham as a faithful aide, prophet, and servant, and had therefore been endowed with a life so long that it would last down till the Day of Judgment. The entire time when Israel was in Egypt, they said, he had afforded them aid and comfort in visible as well as invisible form and in many shapes, and even though he had been taken off to heaven in a fiery chariot in Ahab's 
time, he was nevertheless still present invisibly everyday at all Jewish circumcisions in the entire world, for which reason at each of these ceremonies a magnificent special chair was prepared for him which no other of the Jews, be he ever so holy, was permitted to occupy; moreover, they said, he protects and defends the Jewish people and turns away every misfortune which might befall them; but especially he looks with particular favor upon those who, when they celebrate the separation of the Sabbath, called haudila, honor him with wine and certain ceremonies, which is so pleasing to him that he takes such a house under his special protection and heaps rich blessings upon it; so, they say, he will in the future also bring to them Mosciach or the Messiah, and give him a hand in what he undertakes.

In summa, they venerate him more than the Catholics do the Virgin Mary, and to honor him will often feed and give the best treatment to a whole table full of poor folk, but at all times leave a seat empty for him, because they believe he is then sitting with them at the table and invisibly eating and drinking his share along with these poor guests.

About Moschiah and his office, Erasmus told me that the Jews believe that he will be sure to be a worldly king and in wondrous fashion, through great might and divine help, will bring them from all the parts of the world to which they have been scattered back together and to the Promised Land again; and thereby they commingled that which promised the chosen ones eternal life and Moschiach's or the Messiah's reign that promises that there will fall to them here in this world a life as if in an earthly Paradise. God, they firmly believe, will call their dead back to life, eradicate and extirpate all the enemies of the people of Israel, take away all plagues, hardships, and illnesses from them, His people, and build for them once more from precious jewels the holy temple of Jerusalem in the form and manner as the prophet Ezekiel saw it (Ezekiel 40); then the 
people of Israel will rule and reign over the entire world, its property, treasure, and riches from one end of the world to the other; God will free them of innate lusts, inclinations, and temptations to sin and to all evil, indeed He himself will dwell with them so that they may see Him face to face; God will extend their life spans so that one of them will reach the age of Adam or of Methuselah, and any one of them who perished in the hundredth year of his life, of him they would say that he died prematurely in his childhood; the Promised Land, after it has first been purified by fire of the impurities with which the pagans, Christians, and Mohammedans have defiled it, will stretch much farther and will be a thousand times nobler and more fruitful than it now is, just as it was heretofore when the twelve tribes, which consisted of just as many hundreds of thousands of souls, were all therein and were nourished so richly there; their Moschiach will reign forever and upon beginning his realm will keep all the Jews as guests in Jerusalem, at which banquet they will drink the most delicious wine, which grew in Paradise and to this end has been kept in Adam's cellar till ready, and will slaughter the largest animals, birds, and fishes which God ever created, such as the ox Behemoth (Job 40), which grazes off a thousand mountains every day, and what he has grazed during the day grows back at night; and whose mate, so that she might not multiply and so that this race of gigantically large animals not ruin the entire world, God cooled and made unfruitful, and castrated the ox and thus kept it to feed the pious Jews in a future time; also the terrible, great bird Bar Juchne, which must needs supply naught but roasts, and is so large that a single of its eggs which fall out of its nest, crushes and fells three hundred cedar trees, and when it breaks inundates, drowns, and sweeps away sixty villages; no less the great whale Leviathan (of which Job also speaks), which God also castrated so that it might not multiply, and whose mate God slaughtered and salted for the God-fearing Jews who will come back to the Promised Land with their Moschiach. 
Now, since I was very astonished that the Jews, who are otherwise a learned, sly, shrewd, and cunning folk, were so silly that they believed such follies and foolish dreams, Erasmus told me that they doubted that it would come about this way with their future Messiah as little as a genuine Christian doubts that the true Messiah has already (Leviticus 261) come. The so-called Aff or golden age (which the words of Leviticus at the end of Chapter 26 treat as follows: "Even so have I not rejected them when they dwell in the enemies' lands, nor even scorned them that they should be destroyed completely, and my pact with them should not exist any more, for I am the Lord their God, and shall think of my pact, etc.") gives them a particular and yet false hope in this, because that same utterance or promise has already been observed and fulfilled by God in the Babylonian captivity, and the poor blind people do not see they now are living under the curse described in Deuteronomy 28, where not the slightest word is said about any hope of some second salvation. Also, they take particular solace in what Isaiah announces at the end of Chapter 60, where they place in the age of their future Messiah what the prophet asserts about eternal life, namely when he says (Isaiah 60, 18-21, King James version, modified): "Sinning shall no more be heard in the land, wasting nor destruction in the borders; but thy walls will inherit salvation and thy gates be filled with praise. The sun shall no more shine by day, nor shall the moon give light, for the Lord shall be thy everlasting light and thy God thy glory; Thy sun shall no more go down and the moon wane, for the Lord shall be thy everlasting light, and the days of thy mourning shall be ended, thy people shall be all righteous and shall inherit the land forever, the branches of my planting and a work of my hands that I may be glorified. The smallest one shall become thousands, and the youngest one a mighty people. I the Lord will hasten it in His time." So they understand that in their Messiah's time the smallest of the Jews will become many folk, 
and meanwhile these blinded people refuse to see that this prophecy has been fulfilled, in a short time and in greatest haste as it were, in the disciples and apostles of our Lord Christ, namely when each of them in very little time became through his teaching and preaching a great Christian congregation, an incalculable number of many hundreds of thousands of people, whereby the Apostle Peter alone saved nigh on to three thousand souls at Pentecost. They, however, understand these last words (which in Hebrew read: "Oeni Adonai Bocitto Ochysche," that is, "That, speaks the Lord, I shall do in a hastening time") to mean that God will send them their Messiah unexpectedly and in great haste, post-haste as it were, and will put them in the Promised Land as in an earthly Paradise, and these few words they esteem far higher than their golden age, because they imagine that this promise and prophecy has not yet been fulfilled and therefore must needs still be fulfilled, and to be sure when their Messiah arrives. All those "lie-gends" and foolish fables I grasped in my little head as well as if my soul's salvation had been at stake, and I believe, had I been obliged to still learn the catechism, I should not have comprehended it as quickly and as zealously as these foolish fables. To be sure, Erasmus told me probably ten times more than I am telling here, because I am omitting much, not only in order not to be burdensome to the reader, but also because these omissions are not particularly germane to my story; the little which I have told, I think, the reader must needs know so that he may understand right explicitly my story and how I made use of the one and the other thing; also why I did one thing and forbore to do another.

In concluding this chapter, let me mention this one more thing, which of all the foolish matters seemed to me to be the most foolish of all: namely that the Jews believe that when their Messiah comes, the great archangel Michael will blow a large horn three times. At the first blast of the horn the Messiah, David's son, together with the 
prophet Elias, will appear and reveal himself to all the children of Israel, all the Jews in the entire world will hear the sound of the horn and recognize that God has sought out his chosen people and that complete salvation is at hand; upon the Christians and other people will then fall terror, misery, tribulation, and illness; meanwhile the Jews will gird their loins joyfully, take to their legs, and march with great joy with Elias and the Messiah to Jerusalem.

At the second blast, which will be a very long tone, all the graves in Jerusalem will open, God will bring all the dead back to life, and the Messiah, son of David, and Elias the prophet will rouse from the dead again the poor and pious Messiah Ben Joshep (who stayed in Rome under the gate with the sick and the leprous and perished in a battle of the Israelites), then the kings of the people will take on their shoulders and pull in wagons the Jews who are still dwelling amongst them, and will bring them all the way to Jerusalem.

And when the prophet Michael has blown the third time, God will lead forth the Israelites who live over the Gasan brook, Lachlach, and Chobaar, and who dwell in the cities of Judah, who without number will go with the other children of Moses into Paradise; and when the ten tribes of the Israelites draw out, the cloud column of the honors and majesty of God will surround them, yea, God Himself will go before them; before, behind, and beside them will be naught but fire and flame, and they will leave behind for the Christians and the other people on earth naught which might sustain them so that they will be able to live.

I thought to myself: if so many thousand Jews believe this tomfoolery about their future Messiah, and in earlier times for his sake so many of them in Crete, or Candia, wrapped their heads in their cloaks and sprang from a cliff into the sea, then you will surely be able to persuade a simple one of them to let me sleep with his daughter for the sake of the health of their future Messiah. 


\section{Chapter Fourteen}

Elias comes as a dinner guest, the Angel Uriel announces the coming of the Jewish Messiah, and other great miraculous signs occur

I learned to write the above-mentioned words of Isaiah at the end of Chapter 60, "Oeni Adonai Bocitto Ochysche," in which the Jews finally place all their faith, in Hebrew letters so beautifully and elegantly that the two scribes of Solomon, the sons of Shisha, Elihoreph, and Ahia themselves (Kings I, 4:3), could not have done it better. Afterwards I got several sheets of virgin parchment; this I dyed red, yellow, blue, and green, and treated it to make it quite as transparent as glass, so that one could not recognize what sort of material it was, whether it was horn, isinglass, or a talcous substance from which the Muscovites make their windows. This heavenly paper I cut into several hundred little bitty pieces and wrote the above Hebrew words on each of them with golden letters; and after I had also had an alb (that is, a long white robe which Catholic priests use for their church service) made for me of snow-white Dutch linen and a vest to go over it, like an ephod (Exodus 28:4f.), from a multicolored golden piece of cloth, and especially since I not only found myself to have been sufficiently informed by Erasmus about what I needed to know, but had also made and decided upon my plan of how I wished to go about the affair, then I had two blowpipes shafted onto each other and with them blew all my written-on slips of parchment through a broken window into the Jews' school, and indeed on precisely the day on which they were heard chanting with joyous voices the "golden ape" (Leviticus 26). With what reverence, what respect, and what wonderment and inner joy of heart, however, these slips were picked up and 
read by the Jews cannot be put into words. One might get some idea of it when one saw how they trembled with joy, when they read them, when one communicated such a little slip to another, or even gave it to him as a present. It seemed as if each one had in his breast a lute of his own which was making him happy, for each was without any doubt convinced that this was a certain, infallible sign from heaven that now the misery and Diaspora they had hitherto suffered should have an end, and by contrast, their paradisical life in the promised land under their Messiah, who was indubitably already at the door, should begin. Several days in a row I sneaked around invisibly in diverse Jews' houses and saw with wonderment what joy and certain hope those slips had given the superstitious, silly, and deluded folk, how for that reason they indulged in arranged feasts and holiday luxury, and sent some of those slips through the post to Poland, to Italy, to Germany, yea even to Asia, as joyful tidings of their certain deliverance.

The pious Jews have the custom of now and again setting a table for the prophet Elias in their houses, of filling it with poor folk they invite, and of leaving the place of honor free and empty for the afore-mentioned prophet Elias, firmly believing that he is present, although invisibly, so that he may then himself, together with the others, also eat and drink, etc. This custom the Jews now practiced much more than before, because they believed Elias would appear before or at least together with the Messiah. Now since this step had turned out so well for me and I happened to be in Eliezar's house in order to feast my eyes on Esther's beauteous countenance when he gave such a meal, I made so bold as to sit down in Elias' place at the table, and like the other guests fell to so boldly that everyone present, and Eliezar himself, who at the time was personally presiding over the table, was able to see in what measure the food wandered from the serving bowls onto my plate and little by little disappeared 
from it, how my portion of bread decreased and the wine glasses were emptied, all of which was observed with the utmost wonderment and was re- and perceived by Eliezar with even greater joy and satisfaction, so that he poured for me not only common French and German, but even Spanish and Canary wine.

Now when I succeeded so well in this trick in this manner, I became so cheeky and bold that I betook myself not only to Elias' banquets in other rich Jews' houses but even appeared at circumcisions in Elias' place, which great and heretofore, as it were, unheard of miracles soon resounded among all the Jews there and elsewhere in the vicinity, so that I was well able to think that it was now time to proceed to my projected work and to put my plan into effect completely, and without delay.

I had a turner make me an instrument just like a singing top with which little boys amuse themselves, save that the pin or foot was hollowed-out like a pipe, and instead of the square singing-hole in the side I had a round hole which I could screw open and shut; this I filled inside with cotton moistened with the most precious Indian balsam and liquid amber and thoroughly mixed with musk, amber, civet and the most costly aromas of flowers, herbs, roots, gums, and fruits, so when I unscrewed the hole on the head of this instrument and below at the foot and blew through it, I was able to fill any room in an instant with the most lovely aroma a human being ever smelled. This musk-box I took, together with my invisibility, after I had first clad myself in my alb and golden ephod, and had adorned myself in a golden-yellow curly periwig worth 100 thalers and on top a green wreath with jewels on it, and had also painted my face with pleasant colors, and thus decked out I went toward evening to Eliezar's domicile; indeed, I even hid myself in his bedroom (which, perhaps because of the anticipated arrival of Elias and the Messiah he had adorned with tapestries and precious hangings around his bed in the 
most ostentatious way and had provided with a wax candle which burned throughout the night), awaiting with greatest desire till he would go to bed and be in the first stages of sleep.

Now when I attained this desired time, I stepped forth, visibly, in my unusual habit, in my strange peculiar form and borrowed beauty, walked up to Eliezar's bed, and quite neatly waked him from his sleep. "Eliezar," said I, "let your heart not be affrighted and let your spirit be far removed from all needless fear: for, look you, I am the angel Uriel, who stands before the visage of God, dispatched by the King of Kings and His prophet Elias, whom you have served with fear and trembling all your days, to bring you the most joyous message of the salvation of the chosen people of Israel for which the house of Jacob has been sighing for so long a time; for you are the offshoot of the branch of the root of Jesse of Judah, from whose blood is to be born the Moshiach, the holy savior and leader of his people back from the Diaspora and into the promised land, wherein milk and honey flow." When I thereupon paused a little, and he had recovered a little and wiped the sleep from his eyes, he said: "For the Lord all things are possible, to be sure, but how will this be able to happen, for my Sara has grown old and unfit to bear children?" I answered: "It is the will of the Lord and has been ordained by Him that the Messiah be born not of you and of your Sara but of your daughter Esther and of the prophet Elias, who shall get her with child. Look you, God for that reason has so endowed her with virtues, piety, and rare beauty, so that she may be worthy to be the wife of such a great holy and wondrous prophet and at the same time also the mother of your so long awaited Moschiach. Elias has preserved for Moschiach the seed of David from that same king's time down to the present in order to impart it to your daughter Esther on the third day of the month of Elul (that is, September), that begins today; on this day he shall come, invisible as is his wont, to her bed chamber and perform 
the task for which the house of Jacob has been longing for so many hundreds of years; and thus it is that it is written, Elias will appear before Moschiach. Therefore see to it and keep in mind that your daughter behave willingly towards him; you yourself, however, for as long as he stays with her will surely be able to entertain him as is fitting for such a holy prophet, particularly since you have already entertained him many times among the poor folk. From this you shall have this reward and delight, namely that straightway after the birth of her Messiah, your grandson, you shall be rejuvenated like the phoenix or eagle, shall afterwards live without want or illness in the Promised Land longer by far than the 930th year, shall be made by Moschiach a great prince of your people, and shall live to see with joy the demise and ruin of all your and the people of Israel's enemies, but also the eminence of yourself and your family."

Eliezar was rather curious and inquisitive, and therefore also wanted to know some particulars about how the occupation of the Promised Land might occur, and so I was obliged to spin some more lies for him in all haste, were I not to lose my credit with him, and in fact those things which he wished to hear and which are wished for by all Jews; therefore I told him that these would begin in this country, wherein the Moschiach was born, a war which would infect and spread over the entire world; France would make war against Holland; The Holy Roman Empire, Spain, and Holland against France, Sweden, and Denmark; The Poles against the Turks; the Turk against the Persians; the Muscovite against the Tatars, and in summa every people against the other, and in the entire world, and would so fatigue, emaciate, and exhaust themselves, whereby diseases and famine, war's cohorts, would faithfully resist, that the people of Israel, who would meanwhile multiply enormously and would be blessed and preserved by God, would be able to vanquish them quite easily, and in fact without, as it were, even drawing a sword, and make them 
slaves, with the result that they would take away from the peoples of the whole world their best holdings and goods which were mobilia, such as their household furnishings, their goods for sale, and the like, and would have them taken with them to the Promised Land. Thereupon I concluded my exaggerations and told Eliezar that it was not fitting that he know for the present any more of this; he, however, answered: "The Lord's will be done in elevating Israel, and your words be confirmed over His people."

Here upon I again made myself invisible in an instant, blew my poma d'amber toward Eliezar, and thereby made such a strong and lovely odor in the whole room that the poor wretch in his joy thought that he was already halfway to Paradise. And this was really the seal which confirmed the lies I had told as truth; for since Eliezar may perchance have heard or read that evil spirits leave behind them after they appear a foul stench, so he believed certainly and firmly that by contrast good angels depart leaving behind an odor of Paradise, and therefore I could not be an angel of evil or a false apparition, but rather I must needs be a good spirit, particularly since my announcement agreed so well with the slips of paper recently found in the synagogue. What heartfelt joy he felt at this cannot be expressed, and, in fact, why not? He saw himself a grandfather of the Messiah, and next to Him he was, in his imagination, already the greatest prince in the world; he had been assured of a thousand years of life, which he thought to spend without all hardship, as if in the Land of Cocaigne, and according to Him he would most assuredly enter into Paradise anyway and without any difficulty, and not like a cow trying to go through a mouse-hole. He could not wait till it was day to proclaim these joyous tidings to his daughter-she must know that very night what the angel Uriel (I very nearly said "her lover Master Urian") had spoken with him; she too received the pleasant message with the greatest joy, and let the truth of it be confirmed for her by the lovely 
odor which she smelled in her father's bedchamber, and which, for her, I made far more than doubly strong.

Now here every right-thinking Christian should consider with what danger to my soul my carnal lusts had brought me, or, to put it better, onto what a direct path to certain damnation Satan himself had led me, Satan, who, from that day on when I first availed myself of his help through a necromancer, had without doubt obtained greater power over me than he had hitherto had, since at that time he, from becoming my acquaintance and because of services performed for me, had obtained a claim and hold over me of which I should otherwise have surely been free and clear, because of which claim and hold he then was able to incite and drive me on all the more mightily to sins and the most heinous vices. It seems, to be sure, only an amusement and a clever jest that I so masterfully cheated not only the proud Jews and archenemy of both the entire Christian folk as well as our Lord Christ and His churches, but also the proud Jew's daughter of her virginity. But alas, no! my upright, pious Christian soul, there is far more indefensible to it than can be seen at first glance; for firstly, I was imitating the devil himself, who disguises himself as an angel of light in order to deceive mankind. In the shape of this angel I lied not only by the holy prophet Elias, to whom I imputed, in heretical manner and fashion, most heinous crimes, which he could commit, but also by just and faithful God himself. With these terrible and blasphemous lies I strengthened, as much as I was able to, the wretched and blind Jews in the pitiable error of their ways, made more stubborn and obdurate those very Jews, whom God Himself, after all, entices to conversion, offers paternally His mercy, and, if they convert to Christianity, more than willingly and gladly takes into the bosom of His church so that they, together with all chosen ones, may possess eternal blessedness. I, however, with my lies and the false hope I raised, so provided them with arms and 
armor that at that time, even if an extraordinary ray of divine grace had struck them for their illumination, it would nevertheless have been able to cling to them not at all or at best with great difficulty. I made worse and more wicked the very people on whose conversion I should rightly have been intent. "But woe to the man by whom temptation comes!" says the Savior (Matt 18:7), and all this I did to an evil end, namely for the sake of vile and brief gratification of lust which separates the soul from God and places it in eternal death, in eternal damnation. But what was worst of all is that in so doing I offended my very highest good, my faithful God, thereby declared myself His enemy, and deprived myself of eternal life, killed my poor soul once more in the most terrible way, and put myself much closer to the left hand, to the side of the devil and his adherents than I had been heretofore. O, how often we wretched mortals err when we toady ourselves, make our own difficult fall from grace easy, hold it to be a slight defect, indeed not a sin at all, but meanwhile fail to perceive that we are deceiving ourselves and in this our own blandishments and blindness are sinking quite unnoticed with the most loathsome muck of the most terrible vices into hell's abyss. 


\section{Chapter Fifteen}

The Messiah is fathered by Elias, carried by Esther and at last of the great mountains only a ridiculous little mouse is born

Now, when I, as told above, had made Eliezar and his daughter believe (and was myself looking forward to it anxiously and joyously) that on the third day of the month of Elul Elias should appear (or rather that my desire and carnal lusts should be satiated), I nevertheless was unwilling to thank my good fortune, but rather was apprehensive that the Jews might trick me, and that they might not rightly trust and believe, but rather might perchance sacrifice me, just as when I was about to begin the work I had in mind; therefore I sneaked around in Eliezar's house the day before to see what they were about, whether they were readying for the coming Elias a bridal bed or a grave, and found that this wretched folk wished to be deceived, so that the prophecy was fulfilled which was made by the Mouth of Truth, in John 5: "I am come in my Father's name and you do not receive me; if another comes in his own name, him you will receive" (John 5:43). And woe be unto him who in his obduracy, like these blinded Jews, is left untouched by the illumination of God's grace, so that he persist without conversion in his refusal to repent! Who should ever have thought that learned rabbis would permit themselves to be persuaded to believe the holy prophet Elias capable of practicing unchastity and through sin and vices displeasing to God, capable of fathering the promised Messiah, to whom they impute, next to God, the greatest sanctity? But those people who think only of their temporal welfare and of what is pleasing to the flesh; also cannot imagine any other but a saint of flesh and 
blood; they have already had nigh on to 19 messiahs and corruptors, and in the future, in their blindness and blundering will not cease to believe more of that ilk, till they either little by little diminish or are converted here and there one by one, so that on that future great day of the Lord few of their great number, which was formerly incalculable, will be left, since for example under emperor Aelius Hadrianus alone, from the year of our Lord 131 to anno 137 many hundreds of thousands of Jews, men, women and children, perished for the sake of their corruptor Barchochetae (who was called "the son of the star"). Rabbi Bereschits (Rabbi fol. 74) said: "Henceforth they ought to call this man not Barkochba, a "child of the star," but Barkostba, that is, a "child of lies," which anecdote Christian Gerson von Recklinghausen, born a Jew but a baptized reborn Christian, tells in his refutation of the Jewish Talmud (lib.2, cap. 9), where he makes mention of many more such false messiahs of the Jews.

But I shall for the time being leave it to others to speak further of this matter and merely tell my story, the gist of which is that Eliezar not only furnished his daughter Esther's bedchamber with bedding, easy chairs, pillows, and other adornments, just as if a royal prince were to be lodged there, but also he provided his kitchen with the very most delicate foods; and all manner of confits were there in super abundance, so that Elias might be well entertained and provided for and might therefore perform his work with all the greater contentment.

I had got up a garment of rough hair together with a leather belt so that my Esther, when she felt me, might have all the less cause to doubt that I was Elias, and often I had seen the ready willingness of Eliezar, his wife, and his daughter, and had seen no less how zealously they had been adorning, beautifying and embellishing their daughter ever since they received the tidings from the angel Uriel, I put on this Elias habit, took my musk-box with me, made myself 
invisible, and arrived at the appointed time in Esther's room, where I straightway made my presence known by the usual aroma (which both daughter, father, and mother had already smelled heretofore in Eliezar's bedchamber) and by a soft rustling sound, whereupon father and mother, together with Esther's maidservant, withdrew and left us alone. She was clad in naught but a sheer nightgown and a velvet bathrobe completely lined with marten fur, her arms and neck adorned with strings of pearls, and her hair in braids and wound atop her head, as is the custom of Jewish brides. The table was covered with all manner of sweet meats, confits, and large gold-plated goblets filled with canary; and Spanish wines were not wanting either; the bed was so preciously furnished and decorated with silk hangings, with a silken coverlet embroidered with gold and pearls, with the very softest feather mattress, and, as far as linen was concerned, with sheets and pillowcases of the very finest Dutch linen cloth, that it would have been good and majestic enough, were it the Turkish emperor or the Persian shah himself should have had on it his resting place and wrestling-ground.

Now because I was then able to jabber and speak Yiddish so nicely that you yourself, if you heard me talk, you would have sworn by hell and high water that I was a Portuguese Jew, but born in Amsterdam, look you. I opened my mouth and spoke to Esther (but I didn't do it so loudly that the people outside the door would have been able to hear and understand) and told her such a fine pack of lies (if you can call a lie fine) that her heart leaped for joy; namely, I first brought her greetings from Paradise, from all the patriarchs and prophets of the Old Testament, with many congratulations and tidings from the King of the World (for this is what the Jews are wont to call God when they are most devout, even though we Christians, following the example of our Savior, call the evil spirit a prince of this world) because she was to conceive by me and bear for me the Moschiach, 
about whom the entire heavenly host was joyous, from which every pious soul can determine how completely wanton, godless, and frivolous those who once begin to wade along in the dissolute filth and muck of sins are wont to jest with heaven itself and its holy inhabitants, whereby these folk who have forgotten God, without doubt because they are blinded by the wicked fiend, neither note, heed, nor observe the magnitude and loathsomeness of the sins they commit. My Esther accepted everything as much more well-known and true than in the past her parents had that which the prophets, or what the holy Gospel, Christ and his apostles had proclaimed to them. She said: "Do to me what the Lord has commanded you to," and in her mind already saw herself along with her son in Jerusalem a mighty empress over the entire world.

A Frenchman once confessed among other things these formalia also: "I am being merry at ze fair with ze urdy-jurdy gurl!"- "What else?" asked the father confessor.- "I am sleep wiz hur all ze night on ze hay."- "And what else?" asked the father confessor further."Else!" answered the Frenchman. "Ze rest you can probablement figure for yourself." And that is what I shall do here with my tale. Esther was willing, I was hot with lust, the bed was made, the opportunity was there, it was twilight, so any fool can figure what we did with one another. So why should I tell the long and short of it? I simply spent a sweet, pleasant night and thought not in the least about the fact that such a brief, vile gratification of lust drags eternal damnation along behind it, which, had I chosen to consider this trespass of mine, would surely have made this night bitter for me, or even odious to me.

Now when I had sufficiently rammed away the whole night long, I gave Esther to understand, when it became day, that on the same day I must needs be present at several circumcisions, but that I should come to her again that evening; thereupon I refreshed myself with 
some sweet meats and a drink of Spanish wine, and when the opportunity arose, departed, leaving behind the usual sweet aroma, to go home and sleep my fill. This I did for several days and nights in a row, till I was tired, sated, and bored with this business, while good Esther, as is wont to occur in such matters, was skilled at it; and when we parted from one another on the last morning, each of us gave the other a precious ring as a token of remembrance.

After this, Esther truly did not think herself to be a slut and not only she, but also her parents, made much of the grace which had been bestowed on them; but when rumors of her curious impregnation spread among the Jews, they did indeed keep it secret from the Christians, so that nothing untoward, or perhaps even a Herodian trick, might be played on the fruit of her womb (and on the whole Jewish race), which, so they believed, would in the future destroy Christianity; but among themselves they were greatly happy, gloried in their faith, wished each other a happy journey to the Promised Land, invited each other to dine, sent each other presents, and venerated Esther as highly as a goddess. The baptized Erasmus got wind of it from an old and trusted acquaintance, which tidings almost made him waver in his conversion to Christianity, of which, however, I shall speak in the following chapter.

Now the more the Jews' jubilation increased, the closer the time came when Esther was to bear their savior for them and thus make their joy quite complete. Heretofore she had been cared for like a princess, now they had prepared as if for a royal birth, inasmuch as not only the experienced Jewish women, who had often attended at births, but also the most distinguished and richest Jews of the city and the most learned rabbis came to her confinement to kiss now at his first gasp of breath their newborn savior, whom they had already been worshiping anyway while still in his mother's body, and to bestow on him magnificent presents. I had persuaded the many that 
she would in fact bear a child without pain; but look you, when the time came, she began to whimper like other women, and when she had been delivered of her burden, it turned out (alas Adonai! which for the Jews was the worst thing of all) to be a little daughter instead of the Messiah.

Then those present put on long faces and their jaws indeed dropped almost to the floor; and yet the most learned among them were so foolish, so blind, and so obstinate about the Messiah's arrival that they were simply not able to believe what they saw with their own eyes, but rather they spoke and talked the others into believing that it was nothing new in the world for females to be born who only later, when they became of marriageable age, turned into males; accordingly it was decided that they should bring this creature up like a lord, although not because of its strange birth, but rather because of its wondrous conception; who could know, they argued, what God had in mind by hiding the male organ at his birth? Perhaps it must needs not be circumcised till its thirteenth year of age, or who would know? Perhaps the goyim might learn of this birth and seek to kill the Jews' Messiah in his tender youth before he was able to perform miraculous works and bring together the House of Israel and lead it into the Promised Land, whereas in the guise of a female it would be quite safe and sufficiently hidden till it should begin its work; therefore [they thought], they would just have to let God dispose, who was perchance hereby tempting them and thereby testing the firmness of their belief and their constancy, just as he had done also with their father Abraham. 


\section{Chapter sixteen}

How Erasmus reacted, and how he was relieved of his attacks of anxiety

I imagined that I had now so won the heart of Erasmus and inspired in it confidence toward me, both through friendly companionship and daily conversation and through my generosity, which I indeed showed towards him, that I should have wagered a great deal that he would confide and reveal to me all matters of concern to him, which in fact in many respects he did; but after the good man had been informed by some of his old acquaintances from the synagogue about what certain tidings and sure consolation the chosen people of Israel had received from heaven concerning the imminent arrival of their Messiah (namely through the slips of paper which I had scattered without his knowledge), he indeed suffered a violent attack of great sadness at the thought that so shortly before the time when the Jews' misery was to end and their highest bliss was to begin, he had deserted them. However he did not in this case tell me of his great concern, but rather took great pains to conceal it from me as best he could. Now, despite the fact that from his so abrupt change of mind and the many sighs he so frequently heaved, contrary to his former habit and merry humor, I easily saw where the shoe might be pinching him, I nevertheless left him in his suffering till he too received tidings about what miracles Elias had performed and that Eliezar's daughter Esther was already assuredly carrying the Messiah, wherefore he also became quite dismayed and very wavering in his recently assumed Christianity. Then it seemed to me the time and an utmost necessity to give support to this new Christian's soul, which, because of the knavery I had perpetrated, was being undermined and in 
danger of falling and perishing, especially since I suspected that he surely had in mind to change horses again because he did not accept a fine opportunity to embark for the East Indies, as he had desired to, and accept a profitable position which had been offered to him.

Besides, he had also become reticent about telling me, as he had before, much about the Jews' erring and errors in their religion, which seemed to me not an insignificant sign that he must needs no longer be of the same persuasion as heretofore. Now so that I might with good grace come at him to put him in a different frame of mind, I began one day to speak with him about their false messiah Sabbatzi Sevi and his prophet Nathan who emerged in anno 1666, and finally said that were I assured of his discretion, I should be willing to tell him a fine little tale about the way in which I had only recently made monkeys of the Jews. Now when he swore not to breathe a word of it, I told him the entire story of the slips of parchment which I had made and blown into the Jewish synagogue; but since he found it difficult to believe, I showed him the left-over scrap of parchment and even some of the slips, which I had kept because the writing on them had not turned out delicate enough, and also the blowpipe which I had used. He was astonished at this, and answered that this affair with the slips was indeed something of import, but was very slight compared to the new information which he had about the same matter (which had been making him have strange thoughts for a while now), and which he could communicate to me if I likewise were willing to keep silent. I assured him, no less than he had me, of my complete discretion, and he thereupon told me what I already knew before better than he did himself; namely that Esther, the daughter of Eliezar, a wealthy Jew, was with child and was to bear the Messiah, whom she, following divine command, had conceived by a heavenly spirit; moreover, he told me another whole pack of lies about great miracles which Elias was said to have performed in a short time, 
not all of which, in fact, I had done, but rather which the Jews had invented to add to mine; and finally he added, as a final remark, that solely this pregnant Esther had recently kept him from his East Indian journey because he wished to see whether the Messiah's birth would also be as wondrous as his conception had been.

Then I was well able to imagine with what temptations good Erasmus was beset; nevertheless, I did not venture to reveal to him everything about the means by which I got atop Esther in order to thereby rid him of his concern, but I nevertheless did not at all desist from listening to and talking in the matter with contemptuous laughter, with the assurance that once more, as had happened so often before, there was behind this messiahdom trickery and vain hope, which he, as a solidly based Christian and a well-read intelligent man might himself easily judge. Indeed, in earnest and in jest I explained enough to him so that he, a sly cunning fellow, thought further on the matter and finally said: "Were it possible that shrewd Eliezar and his so well guarded daughter, whose virginity was watched over by her mother with lynx eyes, might be deceived, then he could impute his deception to no man other than precisely him who had tricked all the Jews with the blown-out slips of parchment."

I thought to myself: quits! Fritz, you've guessed it! And because I again listened to this with hearty laughter, I put him into even greater doubt, in which I also left him till Esther brought into the world instead of a messiah only a slit-crotch. With that Erasmus's doubts, with which he had hitherto been tormented in regard to religion, reached their end, but on the other hand the longer he thought the more his suspicion increased that I must needs have doubtless had a hand in this affair; but in what manner that might have happened he, as clever as he was, was not able to figure out by himself, because he knew nothing at all about my invisibility and did not even think of anything like that. 
Meanwhile I had even taken him into my service and had so taken him by overwhelming him with gifts and presents that I daily noticed his great loyalty in matter of trade in which I then used him and went so far that I should have been willing to build a castle on him, especially since he also began to confide the innermost secrets of his heart and the most secret affairs of his conscience to me better than many a man does to his father-confessor, among other things, and principally too, that he well nigh agreed with the conviction that they had about Esther's daughter, that she was of the male sex and the Messiah and that God was concealing her from the Christians in the form as if the child were a little girl till it came of age and was able to perform the deeds it had been born to do. As can easily be imagined, I was obliged to laugh heartily at the simple-mindedness of the otherwise sly Erasmus, and because he had kept secret what I confided to him about the slips of parchment, and had also otherwise given many proofs which assured one that much greater secrets might safely be confided to him, look you, I resolved to reveal the whole business to him, which I then did indeed do, and told him he should believe with certainty that I myself was the father of the slit-crotch messiah; but how I came to be that, and through what advantage and deceit I had outwitted Esther and her parents, I begged him, Erasmus, not to trouble himself about, which deceit I still at this time had misgivings about telling him, but in time it would not remain concealed from him.

"O mirum," Erasmus hereupon said, "I should never have believed that a Christian, a Christian I say, who through holy baptism has been reborn to eternal life and for whom the joys of heaven have been so dearly purchased through the most precious blood of Christ, would commingle himself with a Jewess, the sort of women who are all commonly deemed by Christians to be not much better than dogs and are even called dogs by them (unless they have been cleansed by 
holy baptism and made part of the body of Christendom). I have oft heard tell that in some dishonest places Jews lusting for profit have delivered Jewish girls to some of the lewd whoremongers amongst the Christians (I well nigh take sin upon myself when I, a now baptized Christian, say that, but who can do anything about loose folk who hap to be our brethren), and pretend that these Jewish girls are common women of the Christian faith, and afterwards glory in the fact that they have so masterfully bested these sinners and deceived them with their, the Jews', own ilk, whom they curse and call bitches; and the Jews say that were they dogs and not just as much human beings as the Christians, then a Christian would indeed easily be able to notice when he was sleeping with a Jewess that he was having to do not with a human being but with a bitch." Accordingly, he added, he was unable to believe that I had been so conscienceless and lewd as to commit such a grave sin, which was to be considered the first cousin of sodomy.

Here, to be sure, Erasmus struck me to the quick and so stirred my conscience that I went into myself powerfully and in my mind beat my breast, particularly because I had vexed this new Christian and before committing that sin had not better weighed and considered the magnitude of it, but rather must needs first learn it from one who had formerly been a Jew; but I excused myself to him by saying that unbearable love had blinded me, as it were, and compelled me to do it. Erasmus, for his part, said to me that more than God I had loved a creature who in her present condition was as little capable of eternal bliss as a beast without reason; that I had preferred a brief vile gratification of lust to eternal heavenly joy and that in so doing I had made myself worthy of eternal damnation, which would indeed befall me, were no true penitence to follow. A true Christian ought to struggle against such vices with all his powers so as not to anger his Creator, who has promised him His support in this so that he may 
achieve victory and so that hereafter the just Master of the Battle may crown him all the more magnificently after he has overcome.

This brief but sharp sermon I took, as noted above, very much to heart; but just as one does not suddenly, in one fell blow, become a scoundrel but rather gets to that point little by little, in stages as it were, so also the sinner (especially such a one, like me, as has already long since become mired in all vices) seldom reforms with his whole heart, unless a special glowing grace of God illuminates him. I simply remained what I was, and put all the blame on love, as many other madmen are wont to do, who exert no real earnestness and effort to overcome their desires, or rather themselves. 


\section{chapter Seventeen}

Anyone who wishes to know what is in this chapter must either read it himself or have someone read it to him unless, of course, someone has already told him about it.

At about this time I began to reflect both on how I might get my Esther and our baby daughter out of Eliezar's house and power, and how I might provide for the two of them. I thought to burden good Erasmus with her so that the two should not marry outside their race, and I thought of means by which I might lay hand on a sizable amount of money, which I was going to give to him along with them so that it should lighten for him this burden, which many are wont to find very onerous and repugnant to bear, and should move him to shoulder it gladly. For, dear reader, how heavy must indeed nowadays a thing be in the world to outweigh sweet gold? I well knew, to be sure, that Esther was endowed with much rare and incomparable beauty that far wealthier and more qualified fellows than Erasmus would have considered it a great stroke of fortune, indeed the highest happiness itself were they to have got hold of her for their spouse; but on the other hand, when I observed her and my young half-Jewish messiah-brat, of whom no one other than myself knew of what spirit and flesh he had been built (save what I had told Erasmus about it) and considered that both cow and calf would have to be brought to sale together, then it was not difficult for me to imagine with what affection and constant future faithfulness they might be accepted in that status in which they should live unseparated, were they not provided and bound together with money, as with a golden chain. Moreover, I was not yet so wanton and godless as to cast to the winds unprovided for and leave amongst the Jews my own creature, my 
own flesh and blood, of which fact, I was better assured than many a pious husband; therefore my idea was: look and see where you can get some money.

I did not wish to diminish what money I had on hand and needed for my business, which is the common way of all insatiable misers who, the more they have, the more they desire, and do not have enough till the flames of hell clap together seventeen stadia above their heads; and I was much too slothful, or deemed myself much too well-born to use my invisibility to steal little by little from here and there money by the pound till I had a hundredweight of it so that I might give a million to my wild sprig together with his Jewish tribe; therefore I devised other new schemes, which, however, profited me as the remainder of my history will tell.

Little by little I had made the acquaintances of all manner of folks, and in fact it made no difference to me whether I spent my time with rich or poor, with honorable, bold people or with wicked good-for-nothing ones. Anyone who was upright I treated with all manner of civility, as their estate and humor required, in order to win their affections, and with slight effort bound the needy to me in friendship through my generosity so that, to be sure, I might in the end take in the rich and thus deprive them as much as possible of what was theirs, and so that in the poor I might have loyal servants available for all exigencies. And so I had lads with whom I made merry and passed my time. Among these was one who of them all took me into his confidence most and poured out as it were all the innermost secrets of his heart, and whom I for all that by no means reckoned among my best and most loyal friends, even if he had meant well by me, because his friendship led me down a path on which the end of my life might present the most terrible example of the most pitiable of all tragedies. That, however, things turned out better for me than I ever deserved from God, so that I finally came to 
a recognition of what I myself was, which is no small beginning on the path to a good end, I owe not to that lad's friendship but to God's goodness alone.

The first trick he taught me was how to prepare gunpowder which made no report when shot, but rather gave off only a slight noise, gunpowder, the possession of which is more proper for footpads and highwaymen than for honorable folk, but for which, on the other hand, the former are all the more sharply punished when they are caught. The second one was likewise a gunpowder, one with which you were able to shoot birds so that they were in fact not harmed by it but so stunned that you could pick them up as if they were dead and later, when they came to their senses again, have them alive. Thirdly he taught me how to mix something with gunpowder so that it would affect human beings just as the other gunpowder did birds, so that when one shot a person in the head with a rifle or a pistol which had been shot in this fashion, the person would lie there for an hour and a half or even two hours as if dead, despite the fact that he was not in the least further injured. This last trick, like the first one was of no use to me, unless I should have had my amusement with human beings as well as with birds or should have wished to play the role of a miserable footpad and know the victims would be dead only till I had plundered them and made off with the loot. Nevertheless, that I might be able to do it, if I had wished to, pricked my curiosity; and it was precisely this curiosity which spurred me on to begin this praeludium, and in my unreasonableness I did not consider it anything bad, because all three gunpowders' preparation seemed to me to be in accord with the laws of nature, even though it was the ABC to excel with time in that act which one calls the "black" art, which in the end leads the straightest possible way to the devil.

For after my preceptor noticed my curiosity and saw that I was eager to learn yet more, he presented me other lessons and proceeded 
from the natural to the unnatural art. He and one of his comrades once took me to an isolated spot to test on a cat, which we brought with us, a slip of virgin parchment on which there was written in bat's blood words in a strange unintelligible language, and which was supposed to make one invulnerable if it was bound under the left arm, and when I myself had loaded my rifle, which was otherwise so good that I was boldly able to rely on it, with live powder, and when I tried to shoot the cat with the parchment slip under its left forepaw, look you, the rifle would not fire, even though the powder in the pan completely burned up. After that I fired again almost ten times, but my good rifle did not do me the service of making even a single spark of fire, even though I changed the flint several times and each time put in fresh priming-powder, at which I finally became so mad that I was about to smash it to pieces against a tree, at which action my preceptor's comrade laughed, stopped me and bade me fire one more time, announcing that as a joke he had stopped up the barrel of my rifle or charmed the shot. Thereupon I shot the cat so that the ribs in its body cracked, although not a hair of its pelt, not to mention its fur, was damaged.

Who was more eager than I to be able to do these two fine tricks, too? I promised my two companions to give them in return both what I had and what I did not yet possess, which companions, however, wished to accept nothing whatsoever from me, because of my generosity, so they said, but rather were willing to teach me these as well as other excellent tricks for naught whatsoever. After this I took them to breakfast, and afterwards to their lodgings, where they showed me a written book wherein so many arts, both natural and unnatural were recorded that anyone who had learned and practiced all of them should soon have made himself famous amongst the folk and achieved the reputation of an arch-sorcerer. In it was how to make oneself invulnerable in various ways, and, by contrast, to 
deprive others of their invulnerable condition; how to charm women into falling in love; how to catch game; how to extinguish great conflagrations by magic; how to make oneself invisible; how to conjure up dragoons on a battlefield; and how to bring about many hundreds of other things. They forthwith let me see the proof of some of these tricks by hanging about a cock's neck naught but a piece of straw together with a slip of virgin parchment tied on with a thread which a virgin had spun on a Saturday evening, which cock afterwards acted as if it were carrying a large beam. They had a root which, when held to any sort of lock, straightway burst it open; this so well pleased me, because to my way of thinking it was such an excellent complement to my invisibility that I did not leave off asking for it until I got it from them. Afterwards they showed me many other diverse tricks, namely how to have every day three sure shots; how to pour musket balls which must needs have blood and open up anything that is fortified; how to find and dig up buried treasures; also, how to assure good luck at gaming. Lastly, there were also arts of catching fish and birds with one's bare hands; of having a thaler which, every time it was spent, came back into one's purse; and even of a ducat which, when put over night under one's hat, was joined by nine more ducats; which should have reminded me of Fortunatus' magic purse, had it only happened in good conscience. I found spells to drive thunder and hailstorms away and to elsewhere, which seemed to me not less than being able to make weather oneself. In summa, there became known to me all manner of arts, some of which pleased me and some of which made my hair stand on end, without doubt because I was still a novice and not accustomed to such terrible things. 



\title{
Chapter Eighteen
}

\author{
A golden fish lure with a wooden fish pole, and other \\ dodges
}

The so-called open-sesame root that I got as a present from my above-mentioned two companions looked very much like wood, therefore I shall also call it here a wooden fish pole, and indeed a fish pole because with it I went fishing and caught nigh on to 10,000 ducats; that happened like this.

After I had this fish pole, I tested its effectiveness on nearly all the doors and locks which I encountered, and whenever I touched one with it, it sprang open, so that it never failed me the way my good new rifle had. Because with this root along with my invisibility I found myself so well equipped for thievery I did indeed think to make use of them, mainly because I had in mind anyway to scrape together money to provide for my Esther and her child. But who should more rightly have provided Esther with a dowry than her own father? According to Jewish custom, he would have been obliged to open his generous hand even had I never existed and should he have wished to marry her off to someone as wealthy as himself, which would have without doubt happened had I not got ahead of the Jewish boy who was intended to be her bridegroom and snatched the delicate morsel from under his very nose. Given the just cause which I had, I betook myself invisibly to Eliezar's domicile with a gunny sack and investigated all its nooks and crannies to see where the Golden Fleece-I mean the core of his riches in cash-might be hidden; and to confess the truth, I could not but wonder at the considerable superabundance of not only precious household items and mobilia but also all manner of merchant's wares which he had in supply; for I opened 
divers vaults, sometimes by day, sometimes by night, according to when it was appropriate and might be done quietly and secretly, and did not leave a simple chamber unexamined. At last I came to the very innermost vault wherein were stored the very items I was seeking; there was not only a great deal of silver plate and large minted silver of all kinds there, so that I was shocked and astonished at it as well, but there were also there masses of silver cast in the form of bricks, so that I finally imagined that all the Portuguese Jews in the entire city must needs have put their riches there for safekeeping. Iron chests stood piled up there which were so heavy that I was not able to pick one up from on top of the other, and when I opened the one on the very top with my open-sesame root I found it as full of ducats as a bushel-basket full to the brim with fruit which the vendor pours into the customer's sack. I imagined, to be sure, that the lowermost chests might be filled with precious stones, pearls, jewels and other very precious things, since the top one was so rich; but because for the nonce I deemed it impossible to get to them, I made do with what I saw before me and filled my gunnysack with as many ducats as it would hold and as I thought I would be able to carry. Afterwards I locked everything back up again as nice and neat as I had found it so that no one was able to see anyone had been there, unless it happened that someone should have opened the chest with the ducats.

Thereupon I betook myself with my booty back to my chamber just as invisible as I had gone out the day before, and I shall boldly confess that I have never carried anything as heavy in all my days, wherefore Eliezar would have been little grateful to me, even had he known that I was so troubling myself solely and only in order to provide for his daughter.

Now, after I had brought to safety this considerable sum of ducats, which weighed very near one-and-a half hundredweight, I also began to study how I might get the two persons out of Eliezar's house 
and power for whose sake I had pinched so much money, but indeed in such fashion that it happened with Esther's willingness and to her full satisfaction, which would require, as I thought at the time, as much artifice and cleverness to do as it would effort and labor. And as far as Erasmus was concerned, with whom I wished to mate the Jewess after she had first agreed to convert to the Christian religion, I did not think it would take much effort, because Esther possessed her excellent beauty and I such considerable fine money as might lure him on, either of which, her beauty or my money, would have been strong enough alone to persuade him to close not merely an eye to it but both eyes. But listen how it went, and you will see that I was closer than I might ever have imagined.

I was often not at home when Erasmus thought I was sitting in my chamber, and on the other hand I was often sitting in the room with him when he himself had seen me go off; for in such fashion I was able to watch his actions and transactions and what he did and did not do and to learn from that what was going on with him, what schemes he had, whether he was loyal or disloyal, etc. And one time he thought I had gone for a walk somewhere to my tit-bit, when an old baggage-I meant to say old Jewess-came to him, and after she had greeted him in an uncommon way, more in the Christian than the Jewish fashion, and especially since there seemed to be a great love and confidence between them, I came upon the thought that she might be a creature to whom Erasmus was giving things he took from me, despite the fact that I had never noticed anything like that in him. They say, "A person who doesn't trust others is not to be trusted." I shall concede that that is true, and I had not the slightest cause either to put any mistrust in Erasmus; but all the same, they say on the other hand, 'tis the man you trust who rides off with your horse. Therefore I pricked up my ears in order to hear all the more acutely what manner of business these two might negotiate with one 
another. "Where've you been, my dear Jasanna?" said Erasmus to her. "How is that you come to see me again? It seems to me a hundred years since you've been with me." "My friend," answered Josanna, "I came to you before in the hope of bringing it to pass that the amiable Esther, forsaking Judaism, should become your wife and journey by sea to East India with you and me; but now I come to inform you of the opposite; for, by a miracle look you, she not only conceived by Elias and grew big with the messiah, she has in fact already given birth to him, and indeed, in the form of a daughter, so that if the Christians were perchance to learn of his arrival and because he was to be the destroyer of their empire and kingdoms, were to plot against his life during his tender and innocent years before he might perform his miraculous works and complete the work for which purpose he had come into the world, they might be deceived in their folly and let him live because he was a female creature. As soon as she noticed that she had been chosen by the King of the World to be the messiah's mother and had been visited and got with child by Elias, I no longer dared come face to face with her to give her any words or message about you, as had happened heretofore. At that time I could not figure out the reason why she all at once believed herself to be so great and so abruptly scorned both by you and the Christian religion, since she had after all loved and venerated you more than anyone and the Christian religion far more than Judaic law, so that she had even been of a mind to leave behind her parents and their great wealth and go with you to vexatious foreign lands at the end of the earth, for as she had assured me shortly before she became pregnant, she had already packed up precious jewels of rather great value and had decided to go with them to you, if only she might find a good opportunity, in order to escape her father's inquiries by running away with you and sailing with a fleet to distant lands. But what's to be done now, Erasmus? The hope to possess her is already lost, and 
should the fruit of her womb be the true messiah, which even the very most learned Jews do not doubt, but rather are convinced, as are the most distinguished sages in Poland, Istanbul, and Jerusalem, that in his thirteenth year of age he will turn into a male and then begin the great work of Israel's salvation. If, my dearest Erasmus, such were in truth the case, we should be acting foolishly, should we forsake God's chosen people and not share in his redemption, which is now so close at hand."

Hereupon Erasmus answered: "As far as the amiable Esther is concerned, I have never been able to imagine or firmly believe that heaven, though generous, would honor me with such a divine beauty; nor that Fortune, though blind, would bestow on me, a man of low estate and slight family, such a wealthy daughter; I have always been fearful that my fate would intervene with an objection, which would destroy again the assured hope which had been aroused in me by you as well as by Esther herself; and therefore 'tis advisable for me not to take too much to heart all that has happened. The loss of that which was never mine is easy to get over. If I hoped for something greater than was due me and than heaven ever decided to give me, then I committed a folly, so that I myself now have more cause to laugh than to grieve at Esther's loss, although I must confess that it is difficult to see oneself robbed of that which one really thought to get into one's possession. Regarding the fruit of her womb, because of which you are wavering in your resolve to become a Christian, because you are persuaded that it is the mosiach, I must truthfully wonder most of all at your blindness, for it is certainly no wonder indeed that the Jewish folk have permitted themselves to be led astray so many times by divers deceivers, who pretend to be the mosiach, if they are even capable of believing that a little girl in the cradle is going to be the messiah. Do you not yourself know that women of your religion dare not come to the holy place, indeed nowadays, dare not 
come to the synagogue, so that it seems as if they were excluded from religious services because they are an inferior sex? How, then, can a woman ever become the messiah? But it serves such a folk right, and is no wonder either, if it recognizes a woman as its savior, because heretofore that folk worshiped golden calves instead of God. Believe me, dear Johanna, when I say that I know your mosiach's father, who because of the love he bore for Esther pretended to be the prophet Elias and hung a young daughter on her as a reward for her credulity. And even were it to happen that this fruit, when old enough to take a man, should be changed into a man, that would be nothing new at all, and therefore no miracle, much less a messiah, should be hoped for because of that. For that reason, my dear Josanna, I advise you to put into action the resolve you have long since made and not wait any longer for Esther if she so firmly believes that her daughter is the messiah. Even if you don't have her riches, in which you heretofore placed your hope, to help you, you will nevertheless, when you are converted through holy baptism to God the Almighty, have refuge in Him who will never, ever forsake you."

Josanna listened to this quite indifferently, so that one might well see how confused and doubting her mind was; she was also not able to believe that anyone other than Elias should have got Esther with child, because she knew how closely under the supervision of her parents she was protected from the company of all men. Finally she said to Erasmus that she was going to consider further what she should do or not do, and thereupon went her way and promised Erasmus to come visit him again soon. 


\section{Chapter Nineteen}

\section{Cow and calf are put in the same stall}

When I had sufficiently understood from the discourse of these two that Esther was in love with Erasmus and he also with her, and especially that the two, had I not intervened with my shuttle, had intended to get married and following that run off, but before that to take along from Eliezar some provisions for the journey, I began to regret that I had skimmed the cream oft away from good Erasmus, prevented through my lewdness the conversion of Esther as well as Josanna, and had caused Erasmus himself no few trials of conscience, while on the other hand I had strengthened the Jews in their senseless hopes and expectations; therefore I thought to set this all straightway aright again, although I was not able to restore Esther's virginity for honest Erasmus, in place of which he was to have my daughter for his own. I walked invisibly along out of the room when Josanna left, but straightway came back again invisible in form, went to Erasmus and of course acted as if I had just come from someplace or other, and as if I had met Josanna downstairs outside the house, asking what manner of woman that be who had been with him and what business she had to accomplish here.

Erasmus was so honest and candid that he not only told me their entire discourse, but also added that he and Esther had borne a secret love for each other for a long time, but had never spoken to each other face to face, much less touched one another, but rather Josanna was their Mercury and before that had been Esther's tutress since childhood and had taught her not only all woman's work, such as serving, knitting, weaving, embroidering and the like, but also how 
to read and write German, during which time there fell into their hands Christian books from which both garnered such yearning for the Christian religion that they resolved to accept it and to have themselves baptized; but they lacked people who might give them guidance by word and deed about how to put their salutary project into effect till he, Erasmus, had himself forsaken Judaism for Christianity, since they then not only took heart to confide in him what they had in mind, but also Esther, because of the specially good trust she had come to have in him, Erasmus, because he had become a Christian, gave him through Josanna assurance that she would marry him, provided he think of ways and means by which they might secretly, safely, and indeed in secret escape from her father (who otherwise with his considerable money with which he was able to accomplish everything else, would frustrate their plan), whereupon they decided with one another that all three of them would run away with the next fleet which would start off to Batavia in the East Indies, for which purpose Esther always kept herself provided with a good deal of money and many jewels for use in this trip which they planned; but in the meantime, said Erasmus, Elias had snatched the bread, or rather the delicious morsel of meat, right from under his nose and in so doing had also ruined, through Esther, his desire for the Christian religion, since Esther now deceived herself to be the mother of the Jewish messiah and thus very grand; and he had been told by some of his old comrades that she was being venerated just like a goddess and her child was being cared for and reared almost like a king, so that he no longer had any hope that he might get her as a wife or that she might yet convert to Christianity.

Hereupon I asked him whether he was still willing, if Esther converted to Christianity and if a good piece of money were available for her dowry, to take her and the child. He answered: "I have never in all my days seen her, since she has always been protected from men 
like artistic paintings from dust and smoke; how can I buy a pig in a poke? Secondly, I should be obliged to worry, should I have her, that the memory of her Elias might have more place and love in her heart than myself. Thirdly, there might perchance be bad blood in a marriage if one or both partners remembered that someone else had plucked the first and best flower. Fourthly, 'twill be difficult to tend another's plant like one's own. Fifthly, 'twill be unlikely that the actual mother of the Jewish messiah will agree to espouse Christianity; and finally, how would I be able to escape with my bride and the fruit of her womb, toward which now the hope for salvation of the entire Jewish folk is directed, from the pursuit of Eliezar, whose money everywhere prevails by force? Accordingly, it seems to me to be dangerous to resolve to do this so quickly, unless it be that a clever fellow by means of his wise inventions is able to cautiously remove these dangerous obstacles which I fear; moreover, I should indeed like to know what manner of man that might needs be who would give to Esther, a renegade Jewess, money (and how much of it) for her dowry."

"My dear Erasmus," I said in reply, "I shall answer all the points you have brought up, no matter whether you presented them to me in earnest or, as it seems, in jest. Firstly, indeed, that you have not seen her I am more than willing to believe, for if you should have seen her and should have looked upon her beauty just a little, then you would well know that in her you were encountering no pig in a poke; indeed you would deem, for her sake and to get hold of her, everything which you call dangerous obstacles no more than sport and child's play. Believe me for sure, my dear Erasmus, she is such a woman that, were it possible for me to wed her, she should never ever come to your side. Secondly, that you should vie with Elias, for that I already know an excellent remedy, since I know how I can arrange matters so that Esther shall know and believe naught else 
but that you yourself were the Elias who saddled her with the baby daughter, provided you will be able to love the child, which for my sake will not be difficult for you to do. As far as the third point is concerned, because Esther will hold you yourself to be the one who robbed her of her maidenhood, it will be up to you whether what you worry about in that same point is easy or difficult to do. And it is the same situation with the fourth point, namely if she believes that the child is hers and yours, and you love it for my sake. Fifthly, given this situation, Esther's proud conceit will dissipate by itself, namely when she believes without any doubt that she had in her arms not Elias but Erasmus, who also gave her not a male messiah but a daughter, which attests sufficiently to the fact that she has been deceived; and this perpetrated deceit will in turn spur her on anew to leave off Judaism to accept the Christian faith along with her Erasmus. Sixthly, let me worry about how to deal with Eliezar so that you as well as Esther, the child and Josanna will be brought to safety. Regarding your question about who will give over a bit of money for Esther's dowry and how much, know that I shall be that very man; for just as it behooves you to observe the salvation of her bliss and to bring her to the Christian faith, because in this case she will rely upon you and entrust to you alone the task of making it come to pass, so it is my responsibility, because I deceived her and got her the child, to provide her body together with its young fruit with nourishment as best as possible. But, my dear Erasmus, had you done what you were indebted to do, to which good fortune enticed you and the Christian religion demanded of you, namely had you made haste with Esther's conversion and built on divine assistance and providence more than you worried about flight and temporal welfare, then good, pious, innocent Esther would neither have been deceived, nor should I have become her deceiver and false Elias. But one must make the best of what's done and gone, as the old saw says: 
That man is learned and is wise

Who puts up with all he eyes.

But because for the present it cannot be done and carried out with words alone, come with me to see what money I have collected for the dowry for you both and also so that my child shall be honorably and well brought up."

Thereupon I took Erasmus with me and showed him the 10,000 ducats, which I had snatched from Eliezar's vault, and said: "Look you, my friend, this I give as dowry to Esther and her daughter. Now if you do not find to your taste flesh like this, which is in itself a paragon and so excellently spiced with money in the bargain, then I shall find to take your place ten others who will lick their chops at the prospect of it."

Erasmus was astonished either at my generosity or because in all his days he had never seen so much money in cash together at one time; and when he had recovered, he swore to me that he would wed Esther, should I be able to bring it about, and would keep and rear her child like his own flesh and blood. Now when I had got his oath, I informed him how he should act in this business, and that he should command Josanna, Esther's former trusted servant, to come to him tomorrow. I, however, on that same evening let myself be locked into Eliezar's, indeed even into Esther's bedchamber, where she, together with her child, an old nurse and nannie was wont to lie, where I waited till they all fell asleep. Then I took away with me the baby daughter (who was wrapped like a prince's child in sheets and swaddling clothes embroidered in gold, pearls, and precious stones); and although Eliezar's domicile was so well provided with locks that it would have been impossible for anyone save myself to get out, they really gave me no trouble at all, for my mandrake root opened the path for me every place, and I was so bold as to lock up nice and quietly and neatly behind me again everywhere. 
I got safely with the child to my lodgings, so that no one either saw or heard me, and Erasmus had meanwhile arranged for a wet nurse to nurse the child and then waited with longing till Josanna arrived. To her he showed my little daughter in her princely swaddling, and said to her: "Dear friend, here you see both your messiah and my daughter, which, even though she be a girl, is in the power of both a Christian and her true father, not, to be sure, so as to kill her as a messiah, but rather so as to baptize her and have her brought up in the Christian religion, no matter whether Esther be of assistance or not to her Elias, who, however, for the time being is named Erasmus. What do you say to that, dear Josanna? Can you indeed still hope that it should come to pass that the girl should with time be transformed into a baby boy? I should also indeed like to know what Esther will say to it, when in the future she will see our child sitting not as a messiah in a Jewish temple in Jerusalem, but rather, as a Christian maiden, attending to her devotions in the Christian church and serving the true messiah. I advise you, because you see that the affair with your messiah is a mistake, to take up again now your heretofore formed resolve and to follow me, the sooner the better, in embracing the Christian religion; and probably when Esther, who bore this daughter not by Elias but by me, sees that she has been deceived in her foolish belief that she has borne the messiah, and then accepts holy baptism just as I did, and is willing to have me as her Elias and lawfully wedded spouse, then she may come to me within twenty-four hours. Meanwhile I beg you, go to her, tell her these thoughts of mine and ask her on my behalf to forgive me for having so nicely outwitted and deceived her, reporting that the love which I bore her would not permit me to wait till she came to me from her father's house of her own accord." Finally Erasmus gave Josanna the very same ring which Esther had given me as a token of remembrance when I was sleeping with her that last night (for to that 
end I had given it into his possession), proclaiming that she should take it to Esther, for from it she would actually be able to discern that he was the daughter's true father; and when he himself came to speak with her face to face, he would also tell her, as a better sign of the truth, the conversation which occurred between her and the alleged Elias when the messiah was being forged.

Josanna well nigh lost her wits in wonderment when she saw both the child and the ring and heard Erasmus speak thus; she also gladly accepted the responsibility of delivering the message; and when she came to Eliezar's house, 'twas just at the time when the Jews were consoling Esther for the loss of her child and had persuaded her that Elias had without doubt spirited it away to himself in Paradise, when it would be brought up among the angels and would be nourished with heavenly food till it reached its maturity and was able to carry out the work of saving Israel and reestablishing a kingdom for the Jews. Now this must needs have been firmly believed by Esther as well as by all the Jewish folk who heard report of this wondrous spiriting away, since they were unable to detect that some doors, some windows, some shutters, and some locks in or about the house had been opened. But when Josanna brought Esther the ring and told her what she had heard and seen, she abjured the Jewish religion and was ashamed that she had permitted herself to be so deceived and made a fool of. She was so impatient that she was hardly able to await the coming night, in which she had decided to go over to Erasmus. She packed together as secretly as possible her treasure of gold and jewels; with it she stole away from her father's house and came hurrying to my lodgings after twilight, where Erasmus was able to welcome her and entertain her with speeches, as I had instructed him and the matter required, so that she would nevermore have dreamed that anyone save him had been the presumptive Elias and the real father of her daughter. 



\section{Chapter Twenty}

What else transpired before, during and after the wedding

I permitted Erasmus to behave towards his future wife no longer as my servant, but rather as one who is his own master; but I commanded him what he must needs do and not do; namely to rent for Esther and her child a room of their own, in which Josanna too was obliged to make do, and to provide them in it with all necessities and then to secretly look for a trustworthy cleric who would be fit to completely instruct the two future Christians in what they still did not know about the Christian religion, following that to baptize them both, together with the child, in the presence of sufficient witnesses, and finally to join him together with Esther in wedlock. No sooner commanded than done. I was happy that at one strike I had made three Jewesses into Christians: but because this path was not possible, I indeed feared that I might get slight rewards from it, and Esther seemed to me to be a hundred times more beautiful than ever, for which reason I was then sorely tempted not to do good Erasmus any further service; but if I did not wish to be a real arch-rogue, if I did not wish to vex to death the budding future Christians and ruin again everything I had directed toward a happy conclusion, then I must needs leave it as it was. I believe too that because of this abstemiousness alone, which mortified me mightily, I was vouchsafed the favor of God again and came to mend my ways.

Meanwhile I received a report that Eliezar was secretly having his daughter inquired after and was offering to give a great deal of money to him who would tell him anything about her; now because money is wont to bring about everything one wishes at will, I 
deemed it as fair as it was necessary that I take care of those whom I had put in danger and pondered on means to secretly make the inquiries distasteful to Eliezar.

Just at the time there had arrived in the city a company of English comedians that wished to journey home from there and were only waiting for a good wind to sail over. From them I borrowed a frightful devil's costume: it had a pair of ox horns, a pair of glassy, very fiery eyes, as large as chicken eggs, a pair of ears like a cropped horse, an eagle's beak instead of a nose, a maw like Cerberus himself, a goat's beard, griffen's claws instead of hands and cloven cow's hoofs instead of toes. One was able to spit terrible fire out of it if he wished, and one looked so terrible in it that he might have fallen ill or even died at the sight of it. In this I clothed myself one day and went invisibly to Eliezar's bedchamber, wherein I waited till he had laid down to sleep and his servant, who had undressed him, had left him again. The whole night a wax taper was burning in the room, and when it seemed to me that Eliezar was about to fall into a slumber, I permitted him to see me, stepped to the bed and said in a horrible voice; "Eliezar, if you do not leave off inquiring after your daughter, I shall tear you to pieces! You old fool, will you not grant her rest? Look you, she is in the paradise of her Elias, nursing the young messiah; beware, therefore, that you no longer make so bold as to draw him away from his mother's breast, so that I not be dispatched a second time to whip your neck!" I should have had no need to depart whilst leaving behind a stench I made, which I did do anyway, for Eliezar was so fearful and frightened that he shot his bed so full that I near might have fallen into a faint; and even though I made myself invisible for his very eyes, I nevertheless wandered around back and forth, now visible, now invisible, in the house, in which I knew every nook and cranny, making a terrible racket and bursting open locks on the doors, which, however, I did not close again as I had done when I 
fetched away his daughter. This I carried on so long till I came out onto the lane and finally went home to my lodgings again nice and quietly.

Esther and Josanna were zealous, interim, in comprehending and embracing the tenets of Christianity which they still lacked and which they nevertheless must needs know, and the priest, in his diligence and honest spiritual zeal, did his very utmost, so that soon he notified me and Erasmus that they were sufficiently at ease and instructed to be baptized, wherefore we invited to this festivity some of our best friends whom we needs must have as godparents and witnesses of the holy baptism as well as at the wedding ceremony. Esther and Josanna kept their former names but nevertheless took in addition to them the name Mary; his young daughter however was named Eugenia-I know not why this name pleased Esther. The following day the two budding young married folk also had themselves married by the priest's hand; then I was now obliged to witness with pain with what charming amiability Mary Esther treated her Erasmus, and it was all the more difficult and painful to bear this because I imagined that all the loving glances and friendly pleasantries which Esther bestowed on Erasmus were more properly due me than him, since I was more deserving of them from her than he was. Indeed, 'tis impossible to believe how sour it was for me to watch this marriage which I myself, after all, had arranged with such great effort and danger; but this I believe: if it had not yet proceeded so far, I should nevermore have permitted it to proceed that far, for I felt much more grievous pain and pangs of love for this Maria Esther than I ever had suffered before I touched her several times. However, I was obliged to force myself to conceal as best I might my indescribable suffering, torment and anguish for having let this pretty bird flee and go into another's cage and account myself to blame for it. This marriage was kept so secret that not a soul in the house, much less Eliezar and 
the Jews, became aware of it. And after it was over, I paid Erasmus, in the presence of his Mary Esther and Mary Josanna the $\$ 10,000$ ducats in cash, and did not conceal from them the fact that these had been stolen from Eliezar's treasure for this purpose, because it was his duty to provide his daughter with a dowry commensurate with his wealth, which he would not have done, however, were he to have known that she had embraced the Christian faith; and because the afore-mentioned bride had also taken with her from her father's house a considerable sum in gold pieces, pearls, and jewels, the result was that both she and her bridegroom had brought together a considerable fortune; since I had, over and beyond the 10,000 ducats, a few hundred left which had been Eliezar's, I presented them to Mary Josanna, because I was convinced that she had truly earned them with her loyalty and that she had been the main reason why Mary Esther had come to the Christian religion; but I gave them on the condition that she not leave the newlyweds but rather that she should remain with them till they provided for her elsewhere.

At that time there were rumors in all of Europe that the king of France would really make war on the state of Holland; therefore I dispatched quickly what wares I still had in supply and put my affairs everywhere in order; in which business Erasmus, who knew all about them, was faithfully of help to me. But look you; scarcely were we finished when I received a letter from my cousin, the apothecary, that my wife had gone the way of all flesh. O mirum! Who was more distressed? I? Not, to be sure, that my wife had died, but because the letter had taken a full three weeks to reach me; for had it arrived on time, Mary Esther should never have got Erasmus as a husband. But of what help was that? It was done, he had good fortune, and so he led the bride to the altar. But I-if I was full of whims and crotchets before because of my love for Mary Esther, which had not only flamed up anew again but had doubled, now I was, as it were, quite out of 
my senses. Erasmus, whom I had shortly before provided with the most beautiful woman in the world and had made a wealthy happy man, I now wished were dead. I cursed at the same time his fortune, my misfortune and finally became so enraged and unbearable that very nearly no one was able to abide with me anymore, or get along with me either. Finally something, I know not what, but doubtless no good spirit, gave me the idea that I should sacrifice Erasmus and make Mary Esther herself mine once more. O cruel godlessness! I do believe I should have without any doubt ventured in the end to do it, if God had not protected His own, and if at the beginning of my temptation it had not seemed to me a stale meal to wed a woman who by virtue of my scheming had been slept with by another man, which for a time held my cruelty in check; and faithful God, who, as I said, protects his own, meanwhile opened Erasmus' eyes so that he was able to read my raging melancholy in my really peevish face and was able to surmise where this state of mind might come from and what I might have in mind, because it was no secret to him that my wife was dead; for which reason he absconded one night with his Mary Esther, their child, Mary Josanna, and all his fortune, and sailed away with some folk who were taking flight with much goods to Hamburg, which idea God without doubt put into his head through the voice of his guardian angel. From there he went to Danzig and from there to Lübeck, but whither from there I have since been unable to find out; and so I was left behind at the gates of most extreme despair. 



\section{Chapter Twenty-One}

\section{What the desperate man then undertook}

As long as I was occupied with the affairs which I have related in the last few chapters, I no longer consorted with the artists from whom I had received the open-sesames and learned a number of other arts. However, that Erasmus and his retinue were gone, Mary Esther out of my purview, the wares with which I had been trading moved to another place, and my whole business so much taken care of that I had nothing else particular to contend with save idleness and the concern about the afore-mentioned Esther which I was obliged to endure, look you, then I sought out once more the above-mentioned society. The only thing we did was to practice all manner of arts and have our pleasure and amusement of them, along with devoting ourselves to gorging ourselves with food and drink and to whoring and knavery and all manner of other wantonness, during which disorderly and dissolute life I became forgetful not only of my love for Mary Esther, but also of my hearth and home in my fatherland; indeed, forgetful of all respectability and even of myself.

The cause of this (and nearly all) misfortune was idleness, not idleness per se, to be sure, but when one falls in with bad company when neither body and mind has anything to do or to occupy itself with, but especially when such an idle person is already curious, wanton, young and of means, so that he had no particular need to worry about earning his keep; and just as dry tinder catches fire more easily than a wet sponge, so a person like that is much more apt to be inclined to evil and to his demise and ruin than is one who is laden with, cares, toil and trouble. 
Not counting what I had remitted to home and elsewhere, I still had nearly 2500 Imperial sovereigns in cash which I had got together by both chaffering and pilfering; and since it seemed to me likely that this would not last long, considering the life I was leading, I went back to Eliezar's vaults again to fetch me another troop of ducats, but these fine fellows had fled, because at that time everyone was spiriting off to other places whatever was dear to him, so that it appeared as if the citizens themselves were going to make their extremely wealthy city poor, so that it should profit all the less by their needless efforts. And when I also met with failure in other places where I wished to go pilfering, I was myself forced to quit my present way of life and to choose between one of two others, namely either to return home, get married there, in order to fetch me another troop of ducats, and earn my living by trading as I had before, or to become a soldier. The latter I chose for the following reasons:

One time some men, the least of whom might quite easily pass for an arch-necromancer, invited me to a merry spectacle which they wished to prepare by means of their arts and to show me in order to dispel the melancholia to which I was still subject; which spectacle was to be so arranged that one might see things past, present, and future at it. I appeared at the appointed time, and after all were pledged to silence under penalty of death, I took the seat assigned me along with the others. The room in which we were sitting was not particularly large, but as soon as the theater director who was putting on this play began to read aloud mysteriously from the book which he had before him, it opened up and appeared like the most beautiful and pleasant landscape there can be in the whole world. The ceiling became covered with clouds like the heavens, and afterwards cleared up again so that one was able to see Phoebus riding along properly in his chariot like a miller's cart in a village. On the earth everything was as pleasant to behold as it always is in May; one saw there 
the most pleasant possible fields, green leas and forests, charming gardens full of fruitful trees of all manner of species, and what appeared to be the most charming of all was that one was able to see some of them laden with fruit and yet at the same time amongst them trees in full blossom. In this pleasant region one saw, scurrying about their business, people who were lacking much or little either in health or in anything else necessary for their well being; so much that even the poorest beggars, because of the rich superabundance present, deemed it no sin to scorn good dear bread. One saw people who served the great Numen alone and gave thanks to him in the name of and for the sake of all creatures for the peaceful, yea quite golden age, despite the fact that they themselves did not use or take any more advantage of this merciful blessing and superabundance than was required to merely sustain their bodies, which, however, they treated sparingly enough also. Such people however, were very thinly sown. Some of them were of the opinion that they were not as good as the mindless beast, save that God had adorned them with reason and with His image, because they were capable of sinning and angering God, which, however, was not the case with beasts; on the other hand, one saw an innumerable multitude which transformed themselves from human beings into beasts, so that it had the appearance that a second Circe had again arisen.

It would take me too long to tell and would be vexatious to hear how many a man who whinnied after his neighbor's wife changed into a stallion; how many a lewd adulteress, and all wantons, intent upon inchastity, changed into stinking goats; much less that I should say how many through gorging themselves with food and drink turned into swine, through envy and hatred turned into dogs, through greed and lust for money turned into wolves, through cruelty into lions, and others through other vices turned into all manner of other beasts; for these common and well-known transformations 
were nothing at all new here, but rather, because one was able to see, in this vision which had been conjured up, everything that goes on in the world as if in a reduced form, one had enough to do to turn one's eyes to other frightful metamorphoses, and to be sure to such of which even Ovid should never have dared dream. But why not make a long story short? One saw human beings who turned into veritable devils.

Dear reader, what is a devil other than one who hates God, who is an enemy to those who love Him, who desecrated, abuses and blasphemes His creatures, and in summa perpetrates the worst things that can ever be imagined against God and His people? I am not talking here about the miserable congregation of witches who for this purpose travel to their assemblies by night like the owls and bats, shunning the light; for of these miserable slaves of Satan himself it is sufficiently well known anyway what relationship, similarity, and likeness with the devil they are wont to have. But if you wish to know of more people who come quite close to them, then I should direct you not to robbers, footpads, and other proscribed, Godforsaken rabble of that ilk, but rather simply to an inn wherein a lot of farmhands (not soldiers, who have inherited the name "godless") are sitting together and drinking up and gambling away what they have; there you will hear such a terrible bunch of the most horrible blasphemies spat out that you will think either the devil himself is speaking through their mouths, as from people possessed or the beast in revelations of St. John the Divine, or the jaws of hell itself have opened against God, which God-forsaken fellows deem it but jest and child's play when they wish that 100,000 devils might take them, lead them away through the air (yea, to hell itself) and tear them into 100,000 pieces.

But where am I wandering off to? I merely wished to say that in our vision so many non-humans were crawling around amongst the 
humans that one would scarcely have been able to see any real humans any more even if Diogenes had come along with his lantern. This abomination Phoebus saw from high and screamed at the top of his lungs so that his voice was nearly like to thunder. "Alas!" said he, "How much longer shall I continue to shine on people in their lack of wisdom and tolerate in my eyes their evil, with which they blaspheme the Creator, Who had commanded me, to be sure, to impart my light to good and bad alike?" Jupiter, who right off heard this and perchance thought someone might have seized his lightning bolt in order to compete with him in his trade, forthwith appeared on a light cloud and asked what was to be done.

“Oh, kind Jove!” answered Phoebus, "do you not see how nearly all human beings are straying from the path they should follow and that I am obliged to shine on them in the bargain on the false paths on which they, in their evil, walk, and that I am obliged to torment myself from east to west by observing all manner of non-human abominations? Do you think it not meet that I sigh and lament at that? I tell you, 'twould be no wonder if I were to drive, on purpose, the path as Phaeton, perchance because of ignorance of the thing he undertook, did, thereby setting afire the countryside of the world and extirpating and eradicating from the face of the earth their inhabitants together with the heinous vices of their wickedness."

Jupiter hereupon answered that such action would be too harsh and contrary to the benevolence of the great Numen, and should he, Apollo, undertake it on his own, that too would be culpable; the matter must needs be dealt with in other ways and first of all one must needs investigate to determine for what reasons and motives ill-behaved men were becoming yet more wicked; if the cause were found and eliminated, then one might indeed hope for improvement again, and the world's beautiful structure, together with which they too, the planets, would themselves be obliged to cease to exist, might be 
able to continue to flourish. Thereupon he caused a gentle rumble of thunder in order to thereby assemble the entire host of gods, because Mercury was not present, but on earth burdened with all manner of affairs of state at the courts of divers great lords. Now after a considerable number appeared, Jupiter explained to them everything which would be necessary to do in order to determine the real cause for or as a result of which the human race was moving backward in crablike fashion. Now as the gods and goddesses were beginning to deliberate on this, Mercury too came hurrying in, whom Jupiter sharply rebuked, reproaching him that Vulcan, who was lame, had arrived more than a quarter of an hour before him. But because Mercury is held to be the slyest vocativum among all the gods, he did not wish to toss him into a carrion pit or set him on an ass, but rather so that he might keep him in a good mood, and because he had not, after all heard the problem which he had placed before the gods, he asked him what might be the reason that men were so completely straying from the path which the great Numen had directed them to follow, and were running toward hell. Mercury answered without any forethought at all: "Good Jove, what else might be responsible for that except dear sweet money? For I know better than anyone and am still witnessing every day what manifold power it had to lead askew and ruin men in many ways and fashions."

As soon as Pluto heard this, he gave Mercury a peevish look and said: "How can it ever be possible that the two proper metals of Phoebus and of his chaste sister Diana should be the cause of these vices and abominations about which Apollo himself laments? You are simply an idle gossip and think that because I am at one and the same time the patron god of money and the king of hell, men run toward the realm of hell and thus contrary to the will of the highest Numen simply because they love money. There are other things which seduce them into all sorts of vices. And tell me, you nitwit, 
whether Midas in all the days of his life ever called to the gods more devoutly than when he was surfeited with money and begged to be relieved of it again, for which wish to this very day he is deemed foolish by wise mortals."

Hereupon Mercury said that money did not consist only of gold and silver, but also copper, tin, lead, pig iron, indeed occasionally even of leather, and when he wished to continue to vindicate himself and to defend his opinion, Jupiter imposed silence upon him, in order to collect the votes of the whole host of gods, whose unanimous decision finally was to the effort that in fact the kindness of Jupiter himself was responsible for all those vices and abominations of which Apollo complained; Jupiter had turned over to Ceres the Cornu Copiae, from which she had bestowed on mankind so much and superabundantly that they had become completely petulant, lewd, wanton, and wicked; it was well known, the gods said, that if you treat a goat too well, it will go onto the ice and break a leg. And after Neptune also for his part complained that some mortals whom he had raised from the dust and made important in his kingdom were rebelling not only against his divine power but also against his favorites amongst men to whom he was well disposed because they were good neighbors, so that it appeared as if they wished to prescribe laws to all the natural forces of the world-then Jupiter commanded Mars that he should plunder or prime Ceres' Cornu Copiae a little, like a beehive fat with honey, to see whether mortals might not be brought through shortage and need to recognition of what they were and to how they were defective, and thus to improve themselves; and indeed he was to do this to those whom he found to be in the greatest need of it.

"O kind Jove!" the peace-loving gods hereupon cried, "what power are you giving to this raging madman? What manner of misery will he again bring to the world with his cruelty, misery which 
even the most innocent mortals of all may not escape?" But Jupiter refused to be swayed by these objections, and instead said: "Never fear, great Numen will know how to preserve his chosen ones, even if something of this general affliction should be inflicted on the one or the other; and even if many a God-fearing person should be deprived of his life and wealth in this life, great Numen will, in return for that, delight him on the other hand in his heavenly realm." 


\section{Chapter Twenty-Two}

What else happened, and what is to be learned from this vision

Just as bees suck honey from flowers and spiders poison, good persons derive good from books and evil persons evil. Be a book ever so wicked, a pious person will be able to learn something good from it, and a book cannot be so godly that a perverse person will not be able to take something from it which to his mind is not suitable to confirm him in his perverseness. Do we not see this in heretics, who misuse Holy Scripture itself to defend their erring? But what is the case with books is also the case with other things, such as when one takes in bad histories or sees comedies performed, and the like, and what can be said of these things and learned from them can be much better said of, and learned from, this our conjured spectacle.

The companions for whose pleasure this vision had been presented as amusement and diversion derived the most amazement and the greatest joy from it in the following way: they said what great power was bestowed upon devils when they conducted their magicians and witches around in the air and now and again onto mountains and to isolated spots, arranged their dances and all sorts of jests and scrumptious banquets, and afterwards ruined the fruits of the earth, as they do here and there to those by whom they believe themselves to have been insulted by inflicting on them grave illness, by killing or enchanting all their children, their hired help, and their livestock, and by avenging themselves on them and, by all the magical means and aids of evil spirits, conjuring their property away from them and to themselves; but they gave the least thought to what terrible reward should be given them for this work either in this world or the next, by the most upright of all judges. 
Many a person, on the other hand, were he to see this vision, would have likely discerned without effort, and to his spiritual edification, how noxious idleness, and with it all abominable vices and excesses, is born among people of the world as a result of the plenitude and sufficiency of God's rich blessing, which, in the sweet times of peace can be felt superabundantly and not only employed by men according to their needs but also profligately wasted, whereas, on the contrary, the godly pass by quite disinterestedly these delights and pleasures of the world which others so highly prize, and scarcely honor them with a glance, much less defile themselves with them, whereby the former excite and stimulate the righteous and inevitable wrath of God so that they are beset alike with war, famine and pestilence, in order to drive the prickling of flesh out of the lewd lascivious blood and the excited favorite jackass out of the sleepy soul, to spur the soul on to consider its salvation, and to punish at the same time both body and soul here in this world, and in the next eternally, should no improvement result, and to force it into the eternal kingdom as if on the crossroads of affliction.

Others might have been able to learn in detail from our spectacle how miserable and wretched the peasant is, of whom I know not whether he too is a little proud (as those who imagine themselves to be rich and intelligent are wont to be), or whether I should reckon him to the blind or the seeing, to humankind or the beasts. These ninnies I have oft heard lament and grumble whenever the superabundant blessings of the Almighty, which they call the sweat of their brow-I mean the fruits which they grow from the earth-are not covered with silver in accordance with their thinking and desire. Then they quite unashamedly crave those times in which their wine and corn was worth more, that the price of animals and lard rose, and so on; but they do not give the least thought to the fact that if an egg is to be worth three pence, the farmer in that district won't have a 
single hen left to lay them. When they utter such Midas-wishes, they do not remember that an epidemic must strike their cattle before meat will become expensive, that if fruit is to go up in price, first a bad growing year must needs occur which puts little in their barns, and in summa, if all things are to increase in price in order to make their wares valuable, first a war must befall them which will nicely and neatly rob them of everything for which they hoped to get a high price. If Mars then comes and begins to clean out, or rather lay waste to, their chests, barns, stalls and farms, then they curse both the war and those who began it, and no longer give any thought to the fact that they wished it on themselves by word and have deserved it by deed. In such forgetfulness the peasant doesn't think of mending his ways either, but rather remains the same as he was before, till he either dies of want and hunger, or maintains his life, by the grace of God, wretchedly enough, till the sun of peace shines again, at which point he again begins to live as he had left off living before.

Garzoni employs harsh words when he says that it appears as if the peasant were cursed by God, but be that as it may, as our abovedepicted vision shows, he must needs suffer first and most when a war breaks out, from which follows incontrovertibly that if war is in fact a punishment by God the peasantry deserves it most of all. But 'tis not proper for us to judge maliciously, for the peasant is not the only one punished by the war; rather, the outcomes of wars often demonstrate how Aesop's dog loses his piece of meat when he snaps at a shadow, especially since many a great lord who begins a war kills the goose that before was laying a golden egg for him every day.

Many a person might also have learned from our vision that many folk, if they do not receive as peasants and townsmen the reward for their sins and vices from Mars, afterwards they, as soldiers, are meted out their punishment under this god of war all the more cruelly, and particularly the misbegotten, ill-behaved breed which follows 
not the advice of their parents but the mind of the calf-skin, among which fellows none are wont to be more wanton, vicious and godless than these very peasant lads who, from the time they start tending horses till they fill a ditch or otherwise waste away from disease and hunger behind a hedge or in an old building and are attached and eaten half alive by ravens and dogs, know less than nothing to say about their Christianity and what pertains to the salvation of their soul except abominable blasphemies and rather, from which one gathers, to be sure, that they are of the Christian sort but worse than heathens, since they do not even know and understand what they are cursing and swearing. And these are the same folk from whom the proverb arose: "If you wish to ruin a peasant, take a peasant along;" whereas among others, who likewise are also obliged to go to war, there is a little better discipline and humanity.

And so other people, according to their disposition, might have been able to comprehend and digest how to make profitable use of other precepts, both good and bad, from our vision and spectacle. For my part, what delighted me was when I saw how Mars plundered Ceres' horn and let his followers make a short feast from it. And 'twas high time too, for some of them had been living on their rations for a long time or had otherwise managed badly enough at John Rumblygut's table; and some in some places had become as worthless as goose-shit, so that dogs were well nigh loath to piss on them; moreover, the enemy country required of itself that it be purged of these rude fellows, especially since one cannot send them all to India, which one would have liked to do. I observed with heartfelt pleasure how they fleeced the peasant and then each other, so that they ruled in the entire country and everything was theirs that fell into their hands; and before I perceived how wretchedly most of these people finally perished, I felt such a desire to have myself inscribed in their guild that I was well nigh unable to wait till our apparitions 
or vision were at an end. For the miserable groans and lamentations of the dying could not be heard for the screams of the living, who kept on strangling others; or the booming of the field pieces for the noise of the drums, trumpets and kettle-drums; moreover, the haze from so much exploded gunpowder obscured the hideous sight of the wounded, of men shot to pieces in many ways, together with the amount, the rivers, of spilled blood; and those who died and perished of hunger or in a thousand other ways were paid no heed at all by the survivors.

Then I saw, on the other hand, how great lords emptied the cash boxes, the taxes remained uncollected, and treasures vanished; how the merchants became impoverished and went bankrupt; how artisans sang the miserere and gnawed on famine cloth; and how the peasants were wheezing their last breath. There was no house in which there was no weeping, no family which did not suffer, no street which did not wail, no city which did not lament, and no village which misery did not oppress; there one saw no merriment anywhere save amongst the soldiers, and no one enjoying life a little save the warriors; from all the others who were not taking part in the war, there was naught but sighing, mourning, and weeping. All this increased my wish to become a soldier even more.

Our spectacle ended when we saw how villages here and there in the country were plundered and burned to the ground; how fortresses, castles and cities were blockaded, besieged, stormed, taken, robbed or set on fire; and how their inhabitants were oppressed or even chased off; for as we were about to see in how many different sorts of strange, sudden and horrible deaths soldiers perish, namely in water, through fire, in the earth, and in the air, look you, every thing disappeared, and we found ourselves alone again with one another in our room. 



\section{Chapter Twenty-Three}

\section{How the campaign began and proceeded}

Now after I had seen much more prettily than in a painting in what measure everyone must needs yield and subject himself to soldier's bravery, I no longer hesitated to choose what trade I wished to follow and pursue in the future, especially since I was young, strong, straight and healthy, and was not only enveloped in skin hard as iron, like that of Horny-Hided Siegfried, but also was able to penetrate the skin of others who were similarly equipped, was able in extreme dangers to make myself invisible and, on the other hand, was able, when it was necessary, to make several bands of riders appear on the battlefield. What else? I knew how to conjure others' musket barrels shut so that no one might shoot at me if I did not wish it; and on the other hand, I was assured that no one was able to do anything to me; and moreover, all my musket balls were obliged to strike home and draw blood. Equipped with these arts in battle I should be second to no one, but much rather should surpass Hector and Achilles, yea Hercules himself, and thus make myself equal to the famous heathen demigods of old. I was already permitting myself to dream about how every week the extra- and regular newspapers would spread my praise, and how people near and far would be able to tell and boast of naught else but my deeds of heroism. In two weeks at the most I felt certain that because of my incomparable bravery, I should be a captain, a month later a colonel, and, even before a quarter of a year was past, a great general who with his own company would humiliate the king of France and all his brave generals, thereby earn for the United Netherlands the name of the most 
unconquerable of all peoples, and for myself would conquer and effect untold booty and riches and, beyond that, also such honor that they would erect enormous triumphal arches and columns in my honor at all crossroads in the countryside and at all corner-houses and populous squares in the cities and would leave behind for dear posterity for eternal remembrance my great deeds hewn in rock and marble.

And because at that very time the Most Christian King, with the assistance of the king of England was attacking the forsaken Hollanders by land and by sea and by moving precipitately and taking them unawares were making excellent progress, it seemed to me, to be the proper time for me with my bravery to come to the aid of that hard-pressed people (as I called them, because I was very highly flattering myself) and to make them recognize my valor to be far greater than that of a second Martin Schenk.

I did not wish to go into battle mounted, because I was not able to make a horse invisible along with myself, and also particularly because I ventured to think I should otherwise do better on foot; and because I did not wish either to straightway tie myself down as a common foot-soldier, who is not promoted every time he deserves to be, I joined a unit of freebooters who knew as much about war as I did, although they were not as ingenious as I. Among them I stuck out like chaff in a barrel and wished for nothing more than for a sharp engagement; and since there were some skirmishes here and there, I displayed naught but courage and almost more courage than a lion. I jested of musket balls as if they were spitballs being shot from a blowpipe, and for my part laid many a man low with my own musket balls; and even though well nigh every time we were compelled to flee, I was always the last to yield and each time brought home with me, as token and proof of my stouthearted soldierly spirit, some 
booty, which I was quite easily able to do by means of my invisibility without anyone, friend or foe, being able to perceive it.

I often went out alone marauding betwixt the enemy's camps, and wherever I knew or suspected that some of them would pass by, I lay in ambush for them, and even if three, four or even five came ambling up, I nevertheless fired on them; if one of them then fell, which generally happened, and the others decided to screw around to help him out or to see what else was to be done there, I quickly reloaded and laid another one low; and if the rest did not soon ride off on their way, I did no better by the third and fourth, either. If some of them then tried to look for me and to show the one who attacked them that they were soldiers, then I vexed them much worse, because they were not able to see me; and so many times I, all by myself, killed several of them.

This is the life I led, and I added well nigh every day to the money I had with both lawful and unlawful booty, till there was between the two armies more a major engagement than ordinary fight, wherein the victory and the field of battle went to the French. I was equipped with a long flintlock, a cartridge pouch, loaded with five dozen cartridges, and a sharp boar's tusk (I meant to say saber) at my side which was sharp as a razor and split iron wheel-tires in two as if they were turnips, and also opened everything locked up. Thus equipped I thought myself to be the best-protected and bravest hero on either side of the battlefield. I felled as many men as I fired shots before the battle proper began, and because in this action I took up a position by myself (which was permitted me since I was a freebooter) so that the miracles which I performed might be seen all the more clearly by both sides, look you, I withstood well nigh total salvos and caught with my body, frozen as hard as steel, nearly as many musket balls as I had cartridges in my cartridge pouch. Indeed, I actually was so daring as to run into the midst of a brigade of the enemy standing 
opposite us in order to color my saber with French blood; but because I well knew that many hounds mean death for the hare, and especially since musket stocks are so immodest as not to respect one who is invulnerable, I was obliged to let it be and make do with the wish to see them dispersed, so that I might split the enemies' skulls not only during the attack, but also in the mêlée and when they took flight.

But when the enemy made serious preparations to come toward us and to launch an attack (for which reason I again betook myself to our fighting formation), look you, there came, by chance, pounding into my left thigh a single musket ball, which penetrated not only my thief's skin (I rightly call it a thief's skin, for anyone wearing such skin as I did then is stealing from other honest soldiers their lives like not only a thief, but like an assassin and a sorcerer), but also my flesh, bone, and veins. There lay high and mighty foolish and felt in the very greatest need which he had ever suffered in all his days that there are folks on the other side of the mountain too, and that every man meets his match, even if he were the son of the goddess Thetis and were armed with the best weapons that Vulcan ever forged.

I say yet again: there lay high and mighty foolish, the insolent braggart to whom it made no more difference if musket balls struck him like hailstones than if they were gently snowflakes wafting down before he considered that there were some who were as easily able to undo his imperviousness to shot as he was able to undo theirs, ere he remembered that he would no more be able to conjure shut others' musket barrels than others were able to do it and to choke off his shots.

But this was not the only bad thing which befell me; but, further, my magic spells did not help still the bleeding, as a result of which I, in such dire need, in which no army surgeon was immediately at hand, tore up my handkerchief and stuffed it into the wounds. 
Moreover, I was in danger of receiving more such slaps from the salvo which was fired at us, and perchance one which might even blow out my life; and when our side was able to withstand neither the large numbers nor the hot attack of the foe, but rather dispersed (as they are wont to say of them), ran away, and, showing the enemy their backs, left the place where they had fought unhappily and which they had strewn, as proof of their misfortune, with dead and injured; look you, then my terror, fear and anxiety began in earnest, namely when I saw how the victors not only pursued those taking flight but also even killed the wounded lying on the battle field and plundered the dead. In this direct need, when without doubt my time was about to come too, I finally took refuge in my invisibility, so that I disappeared out of the hands of these merciless men, but straightway paid most dearly for this manner of escaping. For when straightway thereafter several large squadrons of horse passed over the battlefield just like thick clouds and thus over me in full gallop, I received from the horses, who no more saw me than human beings did, so many terrible jabs in the ribs that I thought my bones must needs be crushed and ground in my own hide as in a mortar.

When this cruel thunderstorm was past, I lay there quite unconscious and powerless, like one who has been broken on the wheel, and in fact not unfairly, because since the weapons of war had fallen into my hands, I had ungently laid to eternal rest so many an honest mother's son with the aid of my infernal arts. I was able to move neither arms nor legs, and it seemed to me that all my members were broken in two, save my tongue; it still worked, and with it I cursed and consigned to the devil that was in me, all those who had taught me my arts and had thereby caused me and made me so bold as to go to war. I was well able to imagine that if I were to continue to lie there invisible in this way, I really must needs in the end perish and die quite without aid, help, and consolation; therefore I let myself be 
seen again, having made up my mind completely to die willingly. I also tossed away from me what had hitherto made me invulnerable, so that whoever might see me and wish to put me out of my misery might exercise his will on me all the more easily and unimpeded.

And since up till now, without doubt by the grace of God, my head had remained whole and intact, I still had enough of my senses left to consider how I had been living since the hurdy-gurdy girl stole my money. Thereupon there ensued heartfelt remorse and inward sight to the boundless mercifulness of the Almighty at Whose patient benevolence I had not been afflicted sooner by His just and more than well deserved punishment I myself was amazed, together with the firm resolve, should I escape with my life this time (which I really did doubt), to mend my ways and to so arrange and constantly conduct my life to God's honor and to the edification of other people that naught should be reflected by it save a heartfelt love for God and for my fellow man, a profound remorse at the sins I had committed and that I had so often made Him wroth, and lastly an unending expression of gratitude that His goodness had brought back the prodigal son and in the end given him hope that he might be taken into His kingdom. 


\section{Chapter Twenty-four}

\section{How the miserable ninny was delivered from his lamentable condition and set aright again}

Whilst in my wretched misery and distress, I was mulling over the above-narrated thoughts, which without any doubt my good angel put into my head as a result of a special divine glance of grace, I looked about me and became aware that no more (at least few more) murdering soldiers were present on the battlefield, but rather only physicians of the soul and the body, by which I mean to say a priest and several army surgeons or barbers, of whom the former was laboring to heal and bind up the departing souls of the dying and the latter the wounds of the injured bodies. I raised my voice pitiably and called to them, especially however to the pater, crying: "O, noble Christian! Venerable father! Have mercy upon me and permit me to prosper through your help so that just as your grace through your faithful spiritual zeal most assiduously takes pains to see to it that the expiring may reach the blessed place, I may, through your help and cooperation, find help for my body from the surgeons present here." And when he thereupon came up to me I said to him: "I am one of the contingent of Hollanders, although not one by birth, who voluntarily betook themselves hither to defend their fatherland and, as you, good father, can see with your own eyes, have received the reward for the wickedness and rash folly of taking up arms in quite heedless fashion and without any coercion whatsoever, against the arms of the most Christian King; I intend to donate, should I escape with my life, 1,000 Imperial sovereigns to the first monastery which your order undertakes to erect for the beneficence which I receive from your grace; and I intend to pay a second thousand Imperial 
sovereigns for my ransom, for recompensing the surgeons, and, over and above this, to pay separately all my expenses for board." I found merciful ears and well-meaning army surgeons, without doubt because of these lavish promises; each wanted to be the first to practice the business of his profession on me. But inasmuch as I was speaking in a strong voice, and particularly since the army surgeon assured the pater that my life was not yet in any danger, and particularly since I had placed myself in the protection of the pater, despite the fact that it was not his profession to take prisoners, look you, I was laid on four pikes and carried to safety in the clergyman's wagon in the baggage train, where the barbers not only bound my wounds but also put salve on all the bruises I had gotten while still invulnerable to shot when the horses trampled me and the musket balls hit me, and they gave me a drink to dissolve and eliminate the coagulated blood so that I got better things and enjoyed more beneficence than I ever in all my days deserved of either God or the French, in which I was much helped by the fact that I was able to parler their language. My money, which I had on my person and had taken as booty only the day before and which consisted of naught but Louis d'ors, I distributed in several parts among the surgeons, because the pater did not wish to touch it, so that I was not subjected to a body search, and kept in my power the art of making myself invisible.

Several days later my pater came to quarters in Utrecht, just when the pain of my wounds was the greatest and I was beginning to cast up coagulated and clotted blood the length of a coat sleeve; and because my pater for that reason thought I was about to give up the ghost, he admonished me to confess my sins, which I was all the more willing to do because the surgeons had persuaded me that I had been shot with a poisoned musket ball which would probably first make my whole leg inflamed and in the end, contrary to their first better expectations, might kill me. I was inclined to confess, as 
noted, not only because of the fear or anxiety that I might die, but also principally because I now began to palpably notice that since my money had been stolen from me I had been, body and soul, in the power of wretched Satan, who had (perhaps even at the beginning) aroused, moved, strengthened and helped to their fulfillment the divers lusts which I already had, till he had dragged me, as if on a chain, from one sin to another, yea through the abyss and the deepest ruins of sins onto the campus Mortis like a goat onto thin ice, where, in his opinion, I should receive the reward of my folly and should be sacrificed up to him in his infernal kitchen as a fat roast; but I feared that if I were to tell the good pater about all of my adulterous fornications, horrible magic infernal arts, and other rascalries and thieves' tricks, he might become bored and thereby lose all patience; which good father confessors otherwise must needs not lack in the least.

But I found more forbearance than I should ever have imagined, and detected in him a strange joy which he felt, because of which I considered on my own and in detail the magnitude and heinousness of my sins, how low I had fallen, and on what a dangerous twig I was perched, even though he concealed this joy from me. But why should I chatter on to you, dear reader, about how the confession went? I should never hope that you might be so immodest as to deem me capable of telling you about it. Moreover, dear reader, I have indeed already told you in this history so candidly and of my own accord about so many of the wicked deeds I committed that you may well imagine yourself what I and my father confessor might have discussed in the confession, and besides, one is not supposed to divulge anything said in confession, anyway. But this you may know about my confession, and you may believe me surely, that after I had made it and received absolution, I felt as light as if I might be able to fly, although I had felt as heavy before as if a large millstone were pressing on my heart. 
However, what happened to me to my edification after the confession, I am gladly and from the bottom of my heart willing to tell you, esteemed reader, since it is a report which will be useful to you. The entire essence of this short instruction, however, is mainly this: after I had been preserved from temporal and eternal death by God's superabundant grace and mercy, had been raised up again after the severe fall I had taken, and had been pulled out of the deepest quagmire and sink of corruption of most heinous vices in which I had hitherto been mired up over my ears, and had again, it is to be hoped, been placed in the state of God's grace, therefore I should take this to heart every day of my life, with the most humble gratitude toward God and my guardian angel; yea, every instant and moment I should bring this to mind, and by remembering this and calling for divine assistance should labor and exert most zealous diligence to see to it that I nevermore (like a bathed swine who is wont to return to his old morass) fall upon and arrive at the path of abomination which I had formerly taken, but rather should persevere with persistence in the white garment of innocence which I had received in holy baptism and which had now been cleansed again, through penitence, in the blood of the lamb, and should nevermore through my folly lose the grace of God which I had again received. God's mercifulness, my father confessor said, is, to be sure, unfathomably deep and bottomless, but wanton sinners who sinned with serious intent, and of pure wickedness, as I had done, would not always partake of it; what had befallen me, he said, had been a special grace of God.

To rush to hell apace

Is easy in the main,

But to escape that place

All efforts are in vain. 
The citizens of Utrecht, who had no stomach for living under the Most Christian King, but who had been overtaken and compelled by the rapid progress of his victorious forces to be with person and property in their city and in their conqueror's power, were generally deliberating to determine how they might secretly bring as much of their cash money as possible to safety elsewhere, among which persons was my pater's landlord. When he learned that I had been one of the volunteers who had so indefatigably risked his life for the fatherland, and not the least one in heroic bravery either (if one may call the foolhardiness of a rash sorcerer who blindly rushes in, relying on his magic arts "bravery"), he not only developed a particular confidence in me, but also a wondrous affection for me, as a result of which he served me the choicest morsels which were to be had; he visited and entertained me quite often with his friendly conversation and made no secret of the fact that he desired nothing more than to be assured that his cash worries, of which he had several thousand thalers on hand, were in safety somewhere or other. He would rather have a thousand in Amsterdam any time, he said, than two thousand in Utrecht, where he would never be sure that it was his property. Now this was just what I was wishing for, since I should have liked to have with me what I had in Amsterdam, in order to pay the pater the 1000 Imperial sovereigns and whatever else I had promised. When I told him what I had in mind, he was happy to set up a bill of exchange with me, and offered to give me 10 pro cento, whereupon I gave him a letter to my friends there, who had custody of my holdings, with instructions to pay out to my landlord's authorized agent everything save the jewelry and whatever was not minted and issue a receipt on the transactions. And thus I got my money from Amsterdam to Utrecht, which, counting the lagio which the landlord gave me, amounted to almost 3,000 Imperial sovereigns. 
Of this amount I gave the pater 1,000 Imperial sovereigns to use for a new monastery, also 300 Imp. sovs. for my ransom, for I had been given to him by the colonel as a present; to the army surgeons and those who had carried me on the four pikes I gave as a gratuity 200 Imp. sovs., and also to them to heal my wounds, $100 \mathrm{Imp}$. sovs. for both their efforts and for medicaments, and to the pater's servant, because he had diligently attended to me, 30 Imp. sovs. I also wanted to disburse something to our landlord for my board, but the pater would not allow it, and the landlord was not willing to accept anything either, because I had fallen into this misfortune for the sake of the fatherland. Indeed, he assured me that if the unhappy status of the United Provinces were to change again and I were for that reason to offer myself again in the future, he would see to it that there would be bestowed upon me not only indemnification for the harm I had suffered but also, as an example to others, a considerable recompense because of the loyalty I had displayed and the services I had rendered. And in this case this landlord of mine was not merely full of hot air either, for these days there is not a people under the sun except the Venetians who remember with such gratitude and praise those who have been of service to their state as just these Dutch. Years ago they had a ship's captain who, in order to open a path in the polar ice, had two large iron saws mounted on each side of his ship and with them sailed far into the frozen ocean; and even though he was able to achieve nothing because of the great distance and the much too thick ice, he did so much that one must needs wonder at it. And when afterwards the Dutch got into a war with Portugal, which was lying with its fleet at Gibraltar and had blocked off the sea to its advantage with heavy iron chains, this captain put his saws on his ship, sawed the chain in two with them, and was one reason for a magnificent victory of his principals; and even though he lost his life doing this, the Dutch were nevertheless grateful and had it publicly 
advertised and proclaimed that whoever devised the pithiest and most beautiful epitaph for this captain should have as a gratuity 400 florins. Thereupon many ingenious poetic minds went to work, from amongst whom the following two lines carried off both the prize and the 400 florins:

Here he lies who pushed through iron and ice;

At Gibraltar with his life he paid the price.

It sounds far more beautiful in Dutch, and one can find this epitaph hewn in black marble with gold letters in the main church in Amsterdam as a perpetual remembrance. 



\section{Chapter Twenty-Five}

The actual truth about ways of achieving invulnerability

Because I thought to myself that I was now living in an era in which, because of the terrible war, there would be no place safer to dwell than right in the midst of the army of the Most Christian King, to whom all, no matter where they turned, were subjugating themselves, look you, I requested of my pater that he permit me to stay with him till I would be able to go home again in good safety. I found him more than willing to do this, particular since he had managed to obtain the consent of the general staff that he might keep me with him. But that was not all there was to it; rather the pater said to me that if I wished to live in his company, I must needs endeavor zealously to be the man I promised him in my confession to become, namely the sort of person who not only rues from the bottom of his heart the sins he has committed, but also guards himself against them in the future and casts aside everything which might seduce and incite him to anger God further; as far as he could tell, he said, I had by far not rejected completely the most abominable idolatry with which I was more afflicted than any heathen and which lay in the infernal arts with which I burdened myself; he was surprised, he said, that I had not opened my eyes of my own accord instead of after his admonition, that I had not myself considered who it was Whom I had so often and so much scorned and offended, namely God, my Creator, my most kind Heavenly Father, from whom I had everything which I possessed-soul, body, life, physical adornment, strength, beauty, limbs whole and healthy and straight, good sense and reason, sustenance and temporal goods; Who was indescribably 
more loyal to me and had probably shown me more love than had my own parents; Who had not created me deaf, blind, halt, mute, senseless, leprous or otherwise of monstrous form, nor an earthworm or a mindless beast or a thing without any senses, but had rather created me a reasonable, well-formed creature in His own image who was capable, like the angels, of eternal bliss; He who had also promised me life everlasting, which he granted His chosen ones, and had appointed His holy angel to be my tutor, servant, protector and defender; Who had protected me himself and had only recently, in more than visible and palpable fashion, preserved me from death in this life and eternal damnation in the next when wretched Satan (in whose protection I had betaken myself, forsaking God) was about to deliver me up for slaughter and deprive me of both temporal and eternal life by making me self-assured and foolhardy because of both my invisibility and my invulnerability. "Consider, my son," the pater said further, "that in a situation of that sort our just God might probably have permitted to die many a mortal who had perchance not angered Him grossly and so often! O, my child, how can your heart be so hard as not to dissolve into tears when you recognize how often and how grossly you have offended your Creator with your sins, for which He, for the sake of His justice, might so often have damned you, but did not do this, but rather has mercifully waited till this very hour for you to mend your ways; yea, has enticed and called upon you in the most friendly way to reform so that He may make you blessed and may impart to you His salvation. And this is the deed of the Almighty, who has not the least need for you, whose venerability and majesty is praised, honored and adored with trembling and wonder by countless millions of holy angels and mortals, Whose allpowerful indescribable glory, magnificence and most holy perfection neither angel nor mortal may comprehend. Look you, my son! With this most holy and all-powerful majesty you, it seems to me, are still 
in conflict, and you are still an adherent of the devil, who is, after all, the very worst enemy you could ever, ever have, etc."

With these words and more of the like, which, however, I have since forgotten, the honest pater valiantly exhorted me and so touched me to the bottom of my heart that I felt more than sufficiently and my own conscience told me superabundantly enough what manner of honorable fellow I was. But in spite of all that, I sought (without doubt inspired and driven on by wretched Satan himself) other excuses and imagined to myself that I was being reproached by the pater unkindly and too much, because I wished to excuse my sins and blindly refused to be considered an idolater, much less an enemy of God and a servant of the devil; for I said that never in all the days of my life had I ever worshiped the arch-fiend, much less made a compact with him or abjured God; rather the art of making myself invisible had fallen to me by accident and without my seeking or pursuing it; which art perhaps reposed in a natural way in a little root or stone which was in my ant-hill; so, likewise, the arts by which I made myself invulnerable to shot and stopped up the musket barrels of others or undid their invulnerability, were nothing evil at all, since I employed naught but holy and therefore very powerful words to accomplish these things, which words neither the Christian church nor any sensible man anywhere would repudiate and condemn. However, I said, if anyone would demonstrate to me that in practicing these arts I was really acting against God, I should be willing to throw all the plunder I had got from them into the fire and never in all my days to make use of anything of the like again.

Hereupon the pater answered: "My child, you ought not, to be sure, to demand any proof, but rather place complete faith in the artless words of your father-confessor, who is sitting here in God's stead and has no other business before him save to further your soul's blessedness. However, I shall prove by your own example that through both 
the art of invisibility and the art of making yourself invulnerable, stopping up others' musket barrels and the like you have become ensnared in the toils of the arch-fiend and were in fact in his power, so that he might have been able to proceed with you at full gallop to the infernal abyss, had God in His infinite goodness not taken mercy on your wretched state, perfected you up till now; and recently, through the gunshot wound you received (which you should never hold to be a misfortune, but rather the greatest act of grace by God) enticed you to turn to Him again and given you cause to know yourself. I am not talking with you now in confession, of course, but what is said to you should be under the seal of silence which confession requires. You say the art of making yourself invisible you did not intentionally seek, but rather it fell to you by chance. I shall not dispute your allegation, but, my child, do you not think about the fact that you got the material which you are using for it from a necromancer, from an apostle of the arch-fiend; yea, through the assistance of the devil himself? You should have recognized the tree by its fruits even if you had not known that your honorable so-called art of making yourself invisible had come to you through Satan's dealings. For think back, my son, and you will find that your invisibility caused you to fall into the very most abominable sins and vices you ever committed in your life and gave you every opportunity to commit them. What further effort did the wretched devil devote to you to drag you into his realm of the condemned, when with invisibility he had already so roped you that you were running toward hell on your very own accord? It appears as if the arch-fiend would have liked to stop tempting you further since you were his certain pawn, but you, contrarily, were not content simply to be damned, but were much more cruel to your soul than the arch-enemy of souls himself, for it was not sufficient for you to wallow around in the filth of lewdness and incontinence like a sow in the muck; rather you wished also to besmirch yourself 
with the devil's help by stealing, almost as if the sins you had already committed did not make your damnation severe enough; and here it makes no difference whether you stole from a Jew or a Christian. I say not without good right "with the devil's help," for dear friend, what expert in the sciences of nature has ever found out or determined that there is a plant which has the power to cause a lock with steel springs, made by human hands, to spring open? 'Tis Satan himself who, in the form of a root, permits himself to be summoned by curious, perverse men, and who opens locks to help thieves to steal.

Look you, my son, this was the first visible devil which served you and demanded for his efforts naught else save that you should valiantly violate both the seventh commandment and civil law, so that he might bring you if not to the gallows at least all the farther into damnation; and this state of yours at the time would have been dangerous enough and it would have been high time for you to begin to mend your ways, even if you had not had the art of invisibility. But what, miserable man, did you do in this wretched state of yours? Oh, what a pity! You went and in fact forsook the kind Protector of man, Who till then had preserved you from your well-deserved eternal damnation and had mercifully waited for you to mend your ways, and you gave yourself, without any need, over to the important protection of him who goes about like a roaring lion and seeks naught else save to devour your soul! For you 'twas not enough that in a pleasant time of peace you offended the most holy majesty of God by practicing the most terrible vices; rather you also wished to heap the measure of your sins yet fuller in this present war, which is none of your affair in the least, namely when you, like a thief, stole their lives from your fellow Christians, for whom Christ suffered that $\mathrm{He}$ might preserve them. For you 'twas not enough that you had till now carried the devil with you in the form of a root and had broken open locks with it; rather, so that your damnation might be all the greater 
and all the more certain and so that God might be all the more offended and angered, it must also needs have been attested in writing, in proper form, how much and actually you had obligated yourself to the devil, which occurred through the slips of paper which you carried with you on your person or even chewed up and swallowed in order to be invulnerable to shot, particularly since the slips of paper of the Passau art (which bear that name because a student at Passau invented them) have no other content, despite the many signs of a cross written on them, save the following terrible rhyme, which because of its abominableness no Christian ought ever utter, much less let be put down on paper:

Devil, help me fine

And my body and soul are thine.

And it is just the same with this fine so-called Passau art as it is with the many kinds of other invulnerabilities and other sorcerer's arts which consist of words. You say, of course, that nothing that you used was evil, but rather they were naught but holy words and calling on the name of God and His holy angels. I shall not deny that it appears to be that way; but, my son, read the life and especially the confession of the French sorcerer Gaffredi, a priest from Marsilia who troubled himself greatly with those sorts of arts, and also himself invented many of them. And then you will find that sorcerers, when they name the most holy Trinity in these matters, mean Lucifer when they say God the Father, Beelzebub when they say God the Son, Astaroth when they say God the Holy Ghost, and the mother of the Antichrist when they say the Holy Virgin Mary; and that they employ the sign of the cross so often and manifoldly in these matters to no other end than one uses honey with simple-minded folk, such as smearing it on the edge of children's cuts so that one can thereby all the more easily prevail on them to take the bitter drink for worms; 
for the person must needs be quite desperate who straightway from the beginning would knowingly give his soul to the devil, if such pepper was not first sprinkled on the stinking carrion. 



\section{Chapter Twenty-Six}

\section{Continuation of the foregoing material and of other matters of that kind}

"However, a person who makes use of invulnerability sins more manifoldly than he himself thinks; for, firstly, he becomes disloyal to his Creator and Heavenly Father, Who till then has so faithfully preserved him and wishes to continue to protect him further, yea even to bring him into the heavenly fatherland; secondly, he places himself in alliance with and in the protection of, both God's and his own very worst enemy (alas, what a wretched choice, when one holds Satan himself to be higher than God!); thirdly, the devil is hereby worshiped, as it were, and is given the honor of a protector of man, which honor is due benevolent God alone; fourthly, this honor due God alone, without Whose will heaven and earth would not be able to exist for an instant, is stolen from God and given to the devil when the latter is given preference over God and is honored as a preserver of man (and yet is in truth a corrupter of man); fifthly, the most terrible idolatry that heathens ever practiced is hereby committed, which sin is the worst of all and most hated by God; sixthly, does a man not in this instance sin against nature when he does unto his fellow man what he would not wish done by others unto him? Namely when made through the devil's help as hard as iron, he cannot be harmed by his opponent, be he ever so valiant, but rather, seventhly, worse than an assassin who steals the life of one who has left his skin in its natural condition; eighthly, such a person, if no genuine reform ensues, is actually lost forever, for those who employ the above-mentioned Passau art say themselves that anyone who dies in the twenty-four hours after he chews up and swallows 
such a Passau slip of paper goes to the devil. And it is the same with other means of making oneself invulnerable as it is with the Passau art, for if one is good, then they are all good, and if those who use the Alpine plant called chamois root or those who have brought with them from their mother's womb I know not what and are for that reason invulnerable wish to entertain in their wildest dreams the possibility that theirs is an unnatural and therefore also an unjust matter; for they unfortunately do not know at all under what sort of conditions and with what sort of superstitions chamois roots are created, nor what sort of pacts and stipulations at the birth of children the "good-luck" cauls, which they bring with them into the world, are made by some sorts of old women so that the children will be invulnerable. Many other evils might be added in which man immerses himself when he makes himself invulnerable; but, my son, let it suffice for you to know that by so doing you lose the eternal good, which is the very greatest harm of all that may befall a human being. The only other thing to be noted is that upright, honorable, and good folk, both among the soldiery and the civilian citizenry, have no respect for those who make themselves invulnerable; for they say if these people were not faint-hearted, cowardly ninnies, which class of people are otherwise called, if you will pardon the expression, sons of bitches, then they would not desire to draw over them any such scoundrel's birth-caul.

So let this be enough of talk about making oneself invulnerable; in speaking of it, it now occurs to me that I was told that a fainthearted booby appealed to another fellow to let him have a slip of paper which would make him invulnerable; the other one agrees to do it and writes down three times naught but the following: "Defend yourself, you son of a bitch!," wraps it up and gives it to the other one to sew up in his clothes, whereupon he imagined that he was invulnerable, and in all encounters went into battle as boldly as if he 
had been blind and a second Horny-Hided Sigfried, and he each time came away unscathed too, which reminds me of that old story about a woman who got from a traveling medicine man a slip of paper for her eye troubles which she hung around her neck and by which she was cured of her eye troubles. After her father confessor learned of this, however, and was unwilling to permit it because it was a matter of superstitions, but instead demanded of her the slips of paper and opened it, he found on it naught save this: 'May the devil rip out your eyeballs and then shit in the sockets!'

"These would have been, of course, ridiculous things and amusing pranks, had only superstition not been present. But, my son, what indeed do you think was the content of those unknown and unintelligible words that you employed when you made cavalrymen appear on the battlefield, or, to put it more accurately, conjured up so many thousand devils? Might they well have had another meaning save that they obligated and bound you to Satan himself, for the sake of which he so willingly presented himself with a legion of more or less evil spirits and served you? No, verily, the devil does nothing without an eye to a reward. 'Tis dangerous to deal with Jews when they begin to speak Hebrew to one another; how much more so with wretched Satan when one contracts with him in an incomprehensible language, who is after all never found to be without deceit when he speaks clearly and comprehensibly. And the same will have been the case with the words which you used when you conjured others' musket barrels shut or undid their invulnerability."

After the pater said this he paused a little and looked at me as if I were a wretched person for whom one bears great pity and sympathy, which so cut me to the quick that I sat there like a carved statue and nearly died inside for remorse and sorrow. But I recovered myself enough so that I was able to say: "Now I recognize for the first time the magnitude and manifoldness of my grave sins, which 
I did not understand before." "My child," the pater thereupon answered, "twould have been your duty that you ought to have known and understood this; for to this end our faithful Heavenly Father has revealed His divine and most holy will, so that we may recognize it, behave in accordance with it, vanquish our own perverse will and make it conform to His and thereby achieve what our Savior earned on the cross. For this purpose God has given us reason so that we are quite well able to grasp and comprehend His will, and not so that we misuse it on superstitions or anything else which goes against His divine will, but rather we should apply it to His eternal praise and to the accomplishment of our salvation. For this purpose our benevolent Father has given us a mind, so that when we finally, in accordance with our duty, have recognized and grasped with our reason the most holy will of God, we may put in mind this and whatever else pertains to the praise of God and to the accomplishment of our salvation, continuously consider these things diligently and nevermore forget them."

I answered: "Father, you must believe surely that I did not turn over to you and destroy the art of making myself invisible and my other arts with the intent of pursuing my wanton arts further in the future, but rather out of shame, which did not permit me to be so bold as to speak with you about them." "My son," the pater answered, "this shame stems, again, from the cunning and inspiration of the devil, who is attempting to see to it that you should keep these things on your person till in the future, at his then further instigation, you sin with them again, and perhaps more gravely than before, so that he may finally get you in his claws. Through damage to your body and great danger to your soul and your eternal salvation you have already learned whither the devil was misleading you with these infernal arts; and you have, on the other hand, understood palpably enough that only the unfathomable goodness of God at that time 
(despite the fact that you deserved and were worthy of a different fate) preserved you from ruin in this world and the next; yea, called you anew to penitence and thus to the heavenly fatherland. If you are now wise and do not wish to hurl yourself impetuously into hell, then you will easily be able to think what you have to do."

Hereupon I spread out my junk without delay, namely, all manner of slips of paper for making myself invulnerable to shot and other slips with characters and unknown words, some of them written in bat's blood, especially those which one loads into a pistol with a handful of chaff or chopped straw and fires out behind oneself, at which as many troopers of horse appear on the battlefield as there were pieces of chaff or chopped straw. The pater did not deign to read a single one of the slips, but instead (because we happened to be sitting at a fireplace) threw them all into the fire, whereupon there was heard such an explosion in the fire as if over 300 musketeers had fired off a salvo. The fire also forthwith blazed up so mightily and so shot out of the fireplace that we feared the room might catch fire and burn up with us in it. It did not last long at all, however, for scarcely had we taken fright when we heard and saw nothing more; but anyway, for that reason the pater did not wish to throw the root from the anthill which made one invisible into the fire too, for fear that worse might befall us; rather he said I should wrap it up and seal it and give it to him till he was able to give it a different death, without danger to himself, which I was then glad to do.

Meanwhile the pater saw my anxious state of mind, and that I gladly and from the bottom of my heart had done away with my damnable arts; therefore he began to console me again, and said that he was gladly willing to suffer me in his company till I should have the opportunity to get home again safely, admonishing me loyally that I should soon confess my sins again and pour my heart out to God like water; not like wine, which leaves behind in the drinking 
vessel its smell; not like milk, which leaves behind its color; not like oil, which leaves behind some of its greasiness; and not like honey, which leaves behind its taste; for, he said, God wishes to have us completely, and whenever the slightest bit of us is left behind, so that wretched Satan would be able to gain access and get his claws on us again, 'tis dangerous for man.

I promised him to follow his instructions obediently and, in order to mend my ways, to pour my life, as it were, into a different mold, with humble expression of my gratitude to him for his having so loyally espoused my cause and for having brought me, through God's grace, to recognize myself for what I was. He answered that what he had done was his duty, and if I would persist in my good resolve and improve my life so that I achieved salvation, then he did not doubt that God would reward him; I should merely be content, he said, and direct my obedience and humility to God's will.

After that I began to wail and lament that in the entire Christian world so many of the sort of things which I had done were going on, since in part the words and works which people were employing for these things were abominable and terrible, and in part quite ridiculous and yet nevertheless they were all damnable; as, for example, there were the horrible conjurings and alliances with the devil himself, the foolish and superstitious ceremonies and the ridiculous chanting of spells, each of which, even the slightest one, since it goes against the will of God, leads away from God and to hell. What manner of arts old beggar men and beggar women, such as gypsies, practice and teach to others is well known, and that the peasants have spells, magic arts, and superstitious usages which they employ so that nothing can be stolen from them, so that their horses can not be enchanted, so that their cows not be milked dry by demons, and other things of that sort. Some know how to conjure bugs and lice into another's house, others how to drive away caterpillars, ground 
lice, beetles, and other varmints, others how to conjure snakes, and yet others similar magic tricks; some were able to conjure shut the mouths of mice so that they are unable to gnaw anything up; some the mouths of dogs so that they are unable to catch any hares; indeed, there is well nigh no creature or insect with which forbidden magic arts are not practiced, so much so that Praetorius has brought together in his "Pot of Fortune" a whole heap of such superstitious things; and elsewhere more of them have been presented to the world in public print, whereby it is to be lamented that these perverse people mostly misuse holy days, without doubt at the special instigation of Satan himself, such as Good Friday, on which not only do the smiths, completely naked, forge from a gallows chain their rings against epilepsy, but also other abominable things are carried out, of which it is unnecessary to speak and terrifying to hear, such as Walpurgis Night and St. Philip's and St. James' Day, when the peasants through their magic attempt to preserve their cattle for the whole year from being enchanted by sorcery, and know not that they are then themselves practicing sorcery; St. John's night, on which some wicked people to attain invisibility receive fern seeds from the devil and do other evil things, and often run a great risk, as, for example, curious and concupiscent women, who on St. Andrew's night wish to learn what manner of husbands they are to get. Finally, even the holy Christmastide, in which the Salvation of the World was born to us, is not safe from such God-forgetful folk. 



\section{Chapter Twenty-Seven}

\section{Homeward Journey and Conclusion of this little War}

Another fourteen days I spent with my pater in Utrecht after I had become completely healed and healthy again when orders came to him from his superiors to betake himself to Rome by way of Switzerland. Now that was an opportunity I had wished for, to get safely down the Cologne side of the Rhine with him as far as Strasburg, and from there over the Kniebis and all the way home. Therefore I got, through the intercession of the pater, a pass from the French general staff, and set out on the way with him, per pedes, in accordance with the rules of his order. Our company consisted of divers and quite different people; for, first of all, there were the pater and a frater of his order; four French soldiers of divers offices and qualities who had been ordered to Breisach; a parson of the reformed religion who had earlier been called from the Palatinate, where he was born, to Holland and had been so burnt out and ruined in the present war that he was compelled to return home again with his wife; and then a Jew, who was traveling to Frankfurt and whose presence often reminded me, with tormenting pains, of the wicked tricks I had played in Amsterdam; and then, finally, myself, a simple merchant who probably still had 200 Imperial sovereigns with him for food, from which I also loyally procured sustenance for the good honest pater and the brother, since they neither had money nor were permitted to touch it.

Now there were occasionally merry disputations between the pater and the parson, each of whom had as supporters two of the soldiers who were adherents of his confessions, also between the pater 
and the parson on the one hand and the Jew on the other; and even though this Jewish rogue was extremely well educated and knowledgeable, he did not wish to speak right out candidly, but rather said that the Christians should first glue their schisms back together before they made so bold as to convert the Jews, who were united in their faith; for even if one or the other of them would have wished to become a Christian, he would not be able to know to which of the Christian religions he should turn, since each boasted that it was the best! Not only, he said, were the Lutherans daily at odds with one another, but also were constantly at war against the Calvinists Reformed, and were never seen united save when they attacked the Catholics, as, for example, the pater and the parsons were now standing as one man against him, whereas the Catholics opposed all other religions and deemed only their own to be the best. And even though the pater and the parson demonstrated to the Jew that just as ages ago there were Pharisees, Sadducees and Essenes amongst them, there were still today among the Jews and their cochams differing opinions which were, to be sure, at times set aside by essays and mediations invented by the afore-mentioned cochams, but by which the matter was in no way helped nor the religion improved, but rather would be made worse by human dogma and would never bring them to obey their laws as Moses had commanded them to obey them. The Jew, for his part, stubbornly insisted that he must needs first see the Christians united before he would be able to make up his mind to go over to them; the changing of religions, he said, was a serious matter on which salvation depended and was therefore not to be undertaken so lightly and without careful consideration.

The disputations which occurred between the pater and the parson were so diverse, so varied, and so many that I have since forgotten all of them save the following ridiculous episode. As we were marching through the territory of Trier, we passed a pole with a 
wooden statue of the Virgin Mary atop it, before which the pater not only doffed his cap, but also knelt before the mother of our Savior and greeted her with an Ave Maria. Scarcely a half-hour afterward we came to a gallows embellished with a thief, and when we had passed it, the parson said to the pater: "How is it, pater, that you did not kneel down here too? The gallows and the pole with the Virgin's statue are of the same kind of wood, you know." The pater answered: "First inform me about another question, and then I shall reply to yours. I see that you have a wife; you probably kiss her, as other husbands do their wives." "Why not?" answered the parson. "I do not say that that is wrong," said the pater, "but tell me, do you not generally kiss her on the lips?" The parson answered: "Of course. Where else?" "That's all well and good," the pater thereupon said, "but why do you not also kiss her on her bottom? For it is the same sort of skin as her mouth, just as the pole with the Virgin's statue and the gallows are of the same kind of wood. To be sure, 'twould not be a shame for a man either if he, following the habit of the praiseworthy Emperor Carolus Quintus, doffed his hat when he passed by a gallows and said, like the most highly revered emperor: 'Salve, o Sancta Justitia!'” All of us could not but laugh at this, save the parson, who stood there like butter in the sun and perhaps did not yet know that in such circumstances one is wont to be answered the way one has asked.

From this time on the disputing ceased, and we continued our journey together up the Rhine; the parson stopped at Bacherach with friends of his wife, and the Jew in Mainz, and we came with one another without incident to Strasburg, where we rested three or four days and enjoyed according to our need the delicate salmon from the Rhine and the noble Alsace wine; and this was the best place for me also to take leave of the rest of the company.

The pater and his frater accompanied me as far as Kehl and, as long as we were going through the Metzgerau, admonished me 
without surcease to persevere on the path to salvation upon which I had embarked. However, when we came to the Rhine bridge, he drew forth the nests from the anthill, showed me it so that I might see that my seal with which I had sealed it was still unbroken, and said that he knew of no better way to extirpate from the face of the earth the harmful magic which had so shamefully seduced me than to throw the whole plunder into the Rhine. I was well content with that; and he opened the covering where the current of the river was most rapid, and when he got the innermost ball in his hand, he instantly disappeared from the sight of me and the frater. 'Twas a good thing that at that time few people were walking across the Rhine bridge, and no one was around us who saw it, so otherwise the honest pater might have been taken for a sorcerer and seized. His invisibility did not last longer than it took him to cut open the ball and empty the nest out onto a clean bridge piling: then we saw him again. Afterwards he swept the nest, down to the last piece of dust, completely into the Rhine and said: "Now I thank God from the bottom of my heart that this harmful piece of magic has been so happily disposed of in your presence; otherwise you might have thought that I had talked you out of it in order to make use of it myself; but my plan to get rid of it has long been directed at this suitable place."

At Kehl we breakfasted before we took leave of one another, which for my part happened with tears in my eyes; and because I found myself in a land at peace (although I hear that since then it has been quite ruined by the war), and particularly because I still had some money left, I bought myself a horse with which I happily arrived home in a few days. And when I found "The Wondrous Bird's Nest," a so-called little treatise, in public print when I arrived home, and read it, and also saw from the circumstances that this was precisely the same magic object and material which I had had, I thought it meet that I also communicate to the world what happened to me 
with it, and wrote down this, my own history, in the hopes that perchance some would be on their guard to protect themselves from these dangerous magic arts. Whilst doing this, I also devoted myself to making myself, through penitence and godly exercises, worthy of participating in the rewards of the Savior, of receiving forgiveness for my sins and thereby, with God's grace and support, of bringing my life to a blessed

$$
E N D
$$

